\title{
\#USGS
}

science for a changing world

Prepared in cooperation with the

MILLENNIUM CHALLENGE CORPORATION, MILLENNIUM CHALLENGE ACCOUNT, AND

INSTITUTO NACIONAL DE GESTÃO DOS RECURSOS HÍDRICOS

\section{Evaluation of Baseline Ground-Water Conditions in the Mosteiros, Ribeira Paul, and Ribeira Fajã Basins, Republic of Cape Verde, West Africa, 2005-06}
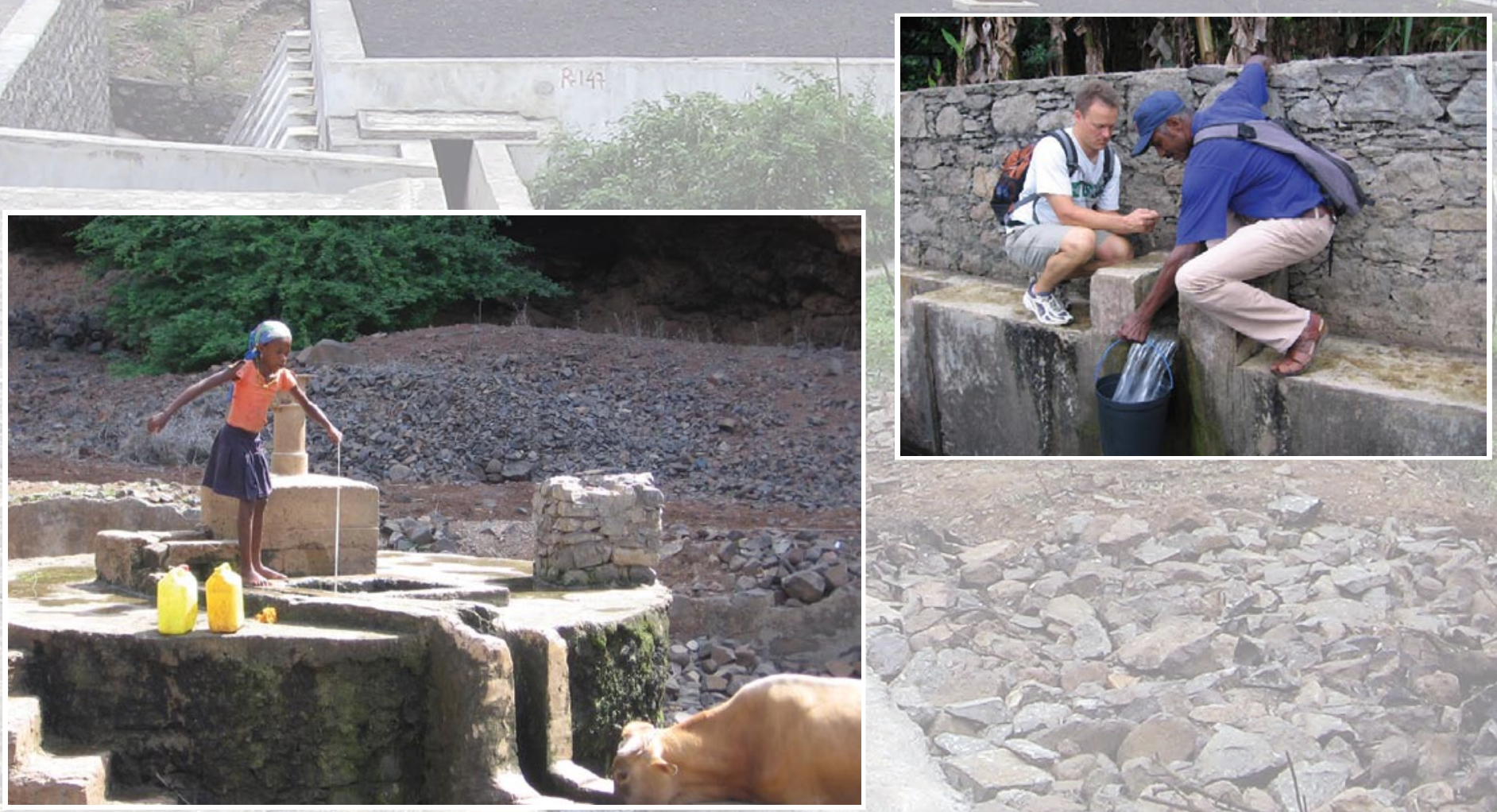

\section{Scientific Investigations Report 2006-5207}

U.S. Department of the Interior U.S. Geological Survey 
Cover photos:

Background-Rainwater catchment structure in the Ribeira Fajã Basin, São Nicolau.

Foreground (left)-Gathering water from a well in the Mosteiros Basin, Fogo.

Foreground (right) — USGS and INGRH technicians making a discharge measurement at a spring in Ribeira Paul Basin, Santo Antão.

(Photographs by Victor Heilweil.) 


\section{Evaluation of Baseline Ground-Water Conditions in the Mosteiros, Ribeira Paul, and Ribeira Fajã Basins, Republic of Cape Verde, West Africa, 2005-06}

By Victor M. Heilweil, John D. Earle, Jay R. Cederberg, Mickey M. Messer, Brent E. Jorgensen, and Ingrid M. Verstraeten, U.S. Geological Survey Miguel A. Moura, Arrigo Querido, Fernanda Spencer, and Tatiana Osório, Instituto Nacional de Gestão dos Recursos Hídricos

Scientific Investigations Report 2006-5207

Prepared in cooperation with the MILLENNIUM CHALLENGE CORPORATION, MILLENNIUM CHALLENGE ACCOUNT, AND INSTITUTO NACIONAL DE GESTÃO DOS RECURSOS HÍDRICOS 


\section{U.S. Department of the Interior \\ Dirk Kempthorne, Secretary}

\section{U.S. Geological Survey \\ P. Patrick Leahy, Acting Director}

Reston, Virginia: 2006

For additional information write to:

U.S. Geological Survey

Director, USGS International Water Resources Branch

MS 420, National Center

Reston, Virginia 20192

http://international.usgs.gov/disciplines/water.htm

For more information about the USGS and its products:

Telephone: 1-888-ASK-USGS

World Wide Web: http://www.usgs.gov/

Any use of trade, firm, or product names is for descriptive purposes only and does not imply endorsement by the U.S. Government.

Although this report is in the public domain, permission must be secured from the individual copyright owners to reproduce any copyrighted materials contained within this report. 


\section{Contents}

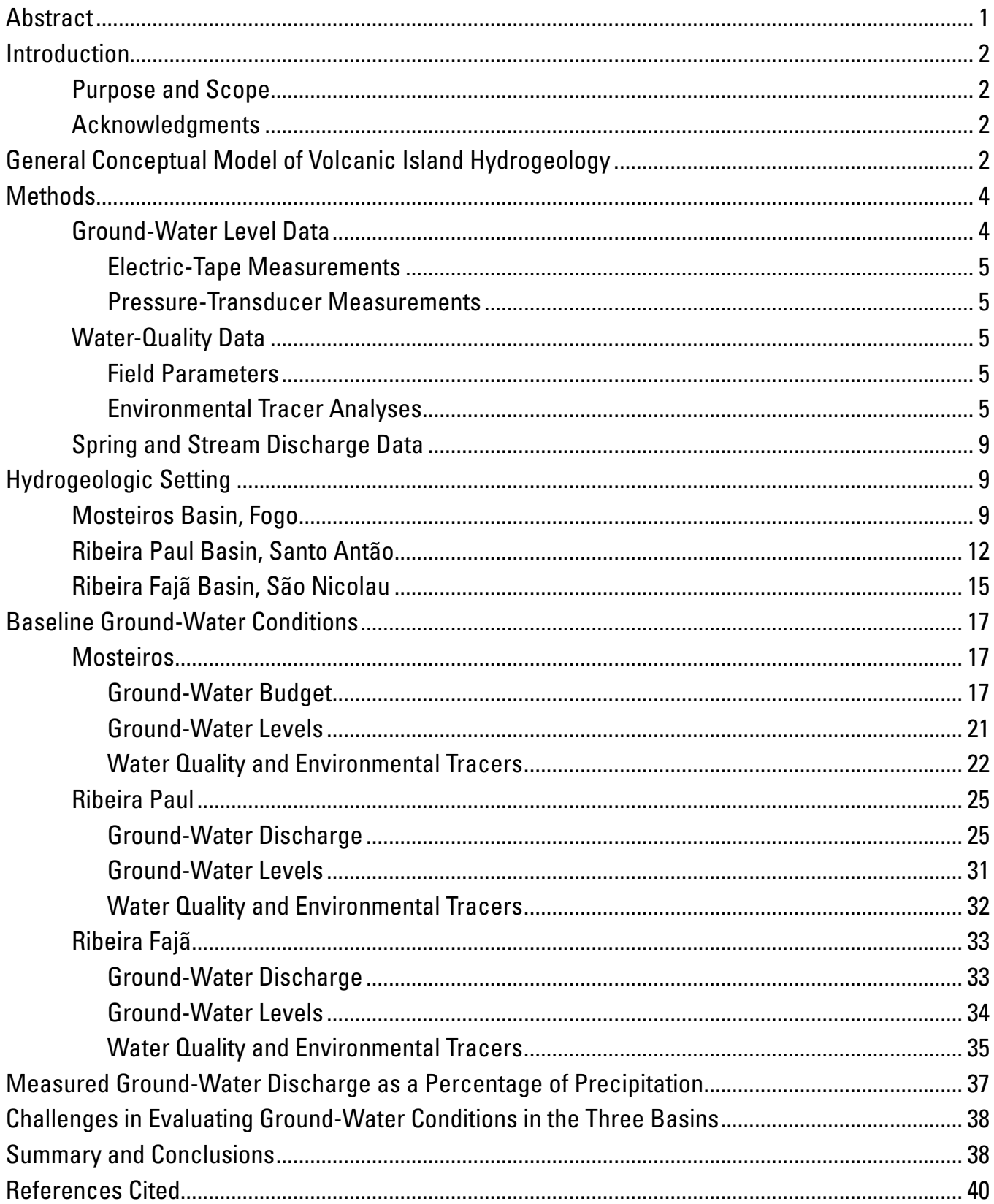




\section{Figures}

Figure 1. Location of the study basins within the Republic of Cape Verde, West Africa ...................... 3

Figure 2. Generalized conceptual model of volcanic island hydrogeology ......................................... 4

Figure 3. Relation between land-surface altitude and water temperature for springs in Cape Verde

Figure 4. Estimated initial and decay-corrected tritium concentration of precipitation in Cape Verde, 1950-2005.

Figure 5. Location of wells, springs, and precipitation stations in the Mosteiros Basin, Fogo,

Cape Verde

Figure 6. Geology of the Mosteiros Basin, Fogo, Cape Verde.

Figure 7. Location of wells, springs, and precipitation stations in the Ribeira Paul Basin, Santo Antão, Cape Verde. 13

Figure 8. Geology of the Ribeira Paul Basin, Santo Antão, Cape Verde.

Figure 9. Location of wells, springs, and precipitation stations in the Ribeira Fajã Basin, São Nicolau, Cape Verde.

Figure 10. Geology of the Ribeira Fajã Basin, São Nicolau, Cape Verde .............................................. 16

Figure 11. Historical precipitation at Posto Cachaço, Ribeira Fajã Basin, 1961-2005 ........................... 17

Figure 12. Total annual well withdrawal and the portion of Monte Vermelho spring discharge used for public supply in Mosteiros Basin, 1998-2005

Figure 13. Water level in well FF07, Mosteiros Basin, December 2005 through March 2006

Figure 14. Depth profile of specific-conductance values at well FF07, Mosteiros Basin, December 2005

Figure 15. Relation between $\delta^{18} 0$ and $\delta^{2} \mathrm{H}$ values in precipitation and ground water from the Mosteiros, Ribeira Paul, and Ribeira Fajã Basins, Cape Verde...

Figure 16. Temperature lapse band and the range of possible dissolved-gas ground-water recharge temperatures for sites in Mosteiros, Ribeira Paul, and Ribeira Fajã Basins, Cape Verde

Figure 17. ${ }^{3}$ Helium: ${ }^{4} \mathrm{Helium}$ ratios relative to the helium isotopic ratio of air and total ${ }^{4} \mathrm{Helium}$ concentration in ground water from the Mosteiros, Ribeira Paul, and Ribeira Fajã Basins, Cape Verde.

Figure 18. Relation between the ${ }^{3} \mathrm{Helium}:{ }^{4} \mathrm{Helium}$ ratio and fraction of ${ }^{4} \mathrm{Helium}$ derived from atmospheric gases in ground water from the Mosteiros, Ribeira Paul, and Ribeira Fajã Basins, Cape Verde 30

Figure 19. Water level in well FA93, Ribeira Paul Basin, August 2005 through June 2006 ................... 31

Figure 20. Galleria Fajã discharge and annual precipitation at nearby Posto Cachaço, Ribeira Fajã Basin, 1984-2005..

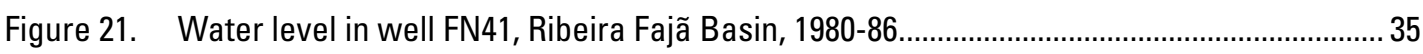

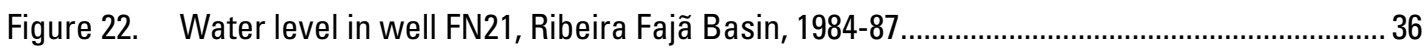

Figure 23. Water level in well FN39, Ribeira Fajã Basin, December 2005 through March 2006 ........... 36 


\section{Tables}

Table 1. Area, slope, and average and maximum altitude of the Mosteiros, Ribeira Paul, and Ribeira Fajã Basins, Cape Verde...

Table 2. Annual precipitation at selected stations in the Mosteiros, Ribeira Paul, and Ribeira Fajã Basins, Cape Verde 12

Table 3. Records of selected springs and streams in the Mosteiros, Ribeira Paul, and Ribeira Fajã Basins, Cape Verde ... 18

Table 4. Records of selected wells in the Mosteiros, Ribeira Paul, and Ribeira Fajã Basins, Cape Verde

Table 5. Selected field measurements, stable isotopes, dissolved-gas concentrations, and estimated recharge temperatures of samples collected from the Mosteiros, Ribeira Paul, and Ribeira Fajã Basins, Cape Verde...

Table 6. Tritium and helium concentration and estimated age of samples collected from the Mosteiros, Ribeira Paul, and Ribeira Fajã Basins, Cape Verde. 


\section{Conversion Factors, Datums, and Abbreviated Water-Quality Units}

\begin{tabular}{|c|c|c|}
\hline Multiply & By & To obtain \\
\hline \multicolumn{3}{|c|}{ Length } \\
\hline millimeter $(\mathrm{mm})$ & 0.0394 & inch (in.) \\
\hline meter $(\mathrm{m})$ & 3.2808 & foot $(\mathrm{ft})$ \\
\hline kilometer $(\mathrm{km})$ & 0.6215 & mile (mi) \\
\hline \multicolumn{3}{|c|}{ Area } \\
\hline square kilometer $\left(\mathrm{km}^{2}\right)$ & 247.0966 & acre \\
\hline square kilometer $\left(\mathrm{km}^{2}\right)$ & 0.3861 & square mile $\left(\mathrm{mi}^{2}\right)$ \\
\hline \multicolumn{3}{|c|}{ Volume } \\
\hline milliliter (ml) & 0.0338 & ounce, fluid (fl. oz) \\
\hline liter (L) & 2.1133 & pint $(p t)$ \\
\hline liter (L) & 1.0566 & quart (qt) \\
\hline liter $(\mathrm{L})$ & 0.2642 & gallon (gal) \\
\hline cubic meter $\left(\mathrm{m}^{3}\right)$ & 264.201 & gallon (gal) \\
\hline cubic centimeter $\left(\mathrm{cm}^{3}\right)$ & 0.0610 & cubic inch $\left(\right.$ in $\left.^{3}\right)$ \\
\hline cubic meter $\left(\mathrm{m}^{3}\right)$ & 35.3107 & cubic foot $\left(\mathrm{ft}^{3}\right)$ \\
\hline cubic meter $\left(\mathrm{m}^{3}\right)$ & 1.3079 & cubic yard $\left(\mathrm{yd}^{3}\right)$ \\
\hline \multicolumn{3}{|c|}{ Flow rate } \\
\hline cubic meter per day $\left(\mathrm{m}^{3} / \mathrm{d}\right)$ & 35.3107 & cubic foot per day $\left(\mathrm{ft}^{3} / \mathrm{d}\right)$ \\
\hline liter per minute $(\mathrm{L} / \mathrm{m})$ & 0.2642 & gallon per minute (gal/min) \\
\hline \multicolumn{3}{|c|}{ Density } \\
\hline cubic centimeter per gram $\left(\mathrm{cm}^{3} / \mathrm{g}\right)$ & 0.0160 & cubic foot per pound $\left(\mathrm{ft}^{3} / \mathrm{lb}\right)$ \\
\hline \multicolumn{3}{|c|}{ Hydraulic conductivity } \\
\hline meter per day $(\mathrm{m} / \mathrm{d})$ & 3.2808 & foot per day (ft/d) \\
\hline \multicolumn{3}{|c|}{ Hydraulic gradient } \\
\hline meter per kilometer $(\mathrm{m} / \mathrm{km})$ & 5.2798 & foot per mile $(\mathrm{ft} / \mathrm{mi})$ \\
\hline \multicolumn{3}{|c|}{ Transmissivity $^{1}$} \\
\hline meter squared per day $\left(\mathrm{m}^{2} / \mathrm{d}\right)$ & 10.7643 & foot squared per day $\left(\mathrm{ft}^{2} / \mathrm{d}\right)$ \\
\hline
\end{tabular}


Temperature in degrees Celsius $\left({ }^{\circ} \mathrm{C}\right)$ may be converted to degrees Fahrenheit $\left({ }^{\circ} \mathrm{F}\right)$ as follows:

$$
{ }^{\circ} \mathrm{F}=\left(1.8 \times{ }^{\circ} \mathrm{C}\right)+32 .
$$

Temperature in degrees Fahrenheit $\left({ }^{\circ} \mathrm{F}\right)$ may be converted to degrees Celsius $\left({ }^{\circ} \mathrm{C}\right)$ as follows:

$$
{ }^{\circ} \mathrm{C}=\left({ }^{\circ} \mathrm{F}-32\right) / 1.8 \text {. }
$$

Horizontal coordinate information is referenced to the North American Datum of 1983 (NAD 83). Vertical coordinate information is referenced to the North American Vertical Datum of 1988 (NAVD 88). Altitude, as used in this report, refers to distance above the vertical datum.

Specific conductance is reported in microsiemens per centimeter at 25 degrees Celsius $\left(\mu \mathrm{S} / \mathrm{cm}\right.$ at $\left.25^{\circ} \mathrm{C}\right)$. Concentration of chemical constituents in water is reported in milligrams per liter (mg/L). Concentration of dissolved gases is reported in cubic centimeters at standard temperature and pressure per gram $\left(\mathrm{cm}^{3} \mathrm{STP} / \mathrm{g}\right)$. Tritium concentration is reported in tritium units (TU). 


\section{Evaluation of Baseline Ground-Water Conditions in the Mosteiros, Ribeira Paul, and Ribeira Fajã Basins, Republic of Cape Verde, West Africa, 2005-06}

By Victor M. Heilweil, John D. Earle, Jay R. Cederberg, Mickey M. Messer, Brent E. Jorgensen, and Ingrid M. Verstraeten, U.S. Geological Survey; Miguel A. Moura, Arrigo Querido, Fernanda Spencer, and Tatiana Osório, Instituto Nacional de Gestão dos Recursos Hídricos

\section{Abstract}

This report documents current (2005-06) baseline ground-water conditions in three basins within the West African Republic of Cape Verde (Mosteiros on Fogo, Ribeira Paul on Santo Antão, and Ribeira Fajã on São Nicolau) based on existing data and additional data collected during this study. Ground-water conditions (indicators) include ground-water levels, ground-water recharge altitude, ground-water discharge amounts, ground-water age (residence time), and ground-water quality. These indicators are needed to evaluate (1) long-term changes in ground-water resources or water quality caused by planned ground-water development associated with agricultural projects in these basins, and (2) the feasibility of artificial recharge as a mitigation strategy to offset the potentially declining water levels associated with increased ground-water development.

Ground-water levels in all three basins vary from less than a few meters to more than 170 meters (m) below land surface. Continuous recorder and electric tape measurements at three monitoring wells (one per basin) showed variations between August 2005 and June 2006 of as much as $1.8 \mathrm{~m}$. Few historical water-level data were available for the Mosteiros or Ribeira Paul Basins. Historical records from Ribeira Fajã indicate very large ground-water declines during the 1980s and early 1990s, associated with dewatering of the Galleria Fajã tunnel. More-recent data indicate that ground-water levels in Ribeira Fajã have reached a new equilibrium, remaining fairly constant since the late 1990s.

Because of the scarcity of observation wells within each basin, water-level data were combined with other techniques to evaluate ground-water conditions. These techniques include the quantification of ground-water discharge (well withdrawals, spring discharge, seepage to springs, and gallery drainage), field water-quality measurements, and the use of environmental tracers to evaluate sources of aquifer recharge, flow paths, and ground-water residence times.

In the Mosteiros Basin, measured well and spring discharge is about 220,000 cubic meters per year $\left(\mathrm{m}^{3} / \mathrm{yr}\right)$. For the Ribeira Paul Basin, measured well discharge, spring discharge, and ground-water seepage to springs is about $1,600,000 \mathrm{~m}^{3} / \mathrm{yr}$. Ribeira Fajã Basin is the driest of the three basins with a precipitation rate of about half that of the other two basins. The only measurable ground-water discharge from this basin is from Galleria Fajã estimated to be about 150,000 $\mathrm{m}^{3} / \mathrm{yr}$. Measured discharge for all three basins does not include submarine outflow or agricultural/phreatophyte consumptive use (Paul Basin, only) and is assumed to be less than total ground-water discharge.

Ground-water ages indicate that recharge to wells and springs occurred from more than 50 years ago at some locations to within the past decade at other sites. Ground water in Paul is younger than that in the other two basins, indicating that recharge generally occurred within the past 50 years. Ground water at all the dateable sites using tritium/helium in both the Mosteiros and Ribeira Fajã Basins show that recharge occurred more than 50 years before the sampling dates. Ground-water tritium/helium age dating was not possible at some sites in Mosteiros and Ribeira Fajã Basins because of the presence of helium in the aquifer derived from the mantle or aquifer matrix. However, this helium was useful for accurate age dating of the unaffected ground-water sites.

Dissolved gases indicate that most ground-water recharge occurs at mid and high altitudes within all three basins; calculated recharge altitudes ranged from 700 to more than 2,000 $\mathrm{m}$. In the Mosteiros and Ribeira Fajã Basins, recharge altitudes are much higher than the wells and springs. This suggests that it may take many years for artificial recharge to result in a beneficial impact on the aquifer in areas where the agricultural projects are implemented. Recharge altitudes in Paul Basin also were generally higher than their respective ground-water discharge sampling sites. Generally younger ground-water ages in Paul, however, indicate the existence of some short flow paths where artificial recharge may possibly enhance available water resources within a few years.

The salinity of wells and springs is generally low in the Ribeira Paul and Ribeira Fajã Basins, but somewhat higher in Mosteiros Basin. Specific-conductance measurements of wells and springs in Ribeira Paul and Ribeira Fajã ranged from about 200 to 700 microsiemens per centimeter at 25 degrees Celsius $(\mu \mathrm{S} / \mathrm{cm})$. Although the Monte Vermelho spring in 
Mosteiros Basin also has very low salinity $(200 \mu \mathrm{S} / \mathrm{cm})$, water from the wells along the coastal plain has specific-conductance measurements of as much as $16,000 \mu \mathrm{S} / \mathrm{cm}$. These higher values indicate some brackish water intrusion. Additional ground-water development of the Mosteiros coastal plain may exacerbate this situation.

\section{Introduction}

The Republic of Cape Verde is an island archipelago located about $750 \mathrm{~km}$ off the west coast of Africa (fig. 1). Its 400,000 inhabitants live on 9 separate small islands with a combined area of $4,000 \mathrm{~km}^{2}$, resulting in one of the highest population densities among the West African nations (Langworthy and Finan, 1997). The majority of the population resides in rural areas and derives its livelihood from rain-fed agriculture. Farming is challenging in the Sahelian climate, dominated by the cool, dry northeast trade winds. Total annual precipitation ranges from 0 to $50 \mathrm{~mm}$ along the populated coastal areas to $400-800 \mathrm{~mm}$ in the highlands and is extremely variable from year to year (Haagsma, 1995). About 80 percent of this precipitation is associated with the equatorial monsoon (August-October; Vailleux and Bourguet, 1974) and comes during only a few days each year. The majority of the precipitation is lost to evapotranspiration and runoff to the sea. The evaporation and runoff losses are caused by a combination of warm climate, thin soil cover, steep topographic gradients, and short distances to the sea. Surface-water resources on the islands are virtually non-existent; there are no lakes and only a few small perennial streams. Nearly all of the water for consumption comes either from rainfall catchment structures or ground water. Because of the lack of rainfall and sparse water resources, Cape Verde currently imports about 70 percent of its food (Instituto Nacional de Gestão dos Recursos Hídricos, written commun., 2005).

To decrease this dependence on imported food, agricultural development projects funded by the U.S. Millennium Challenge Corporation (MCC) are currently underway in three basins on three islands: Mosteiros on Fogo, Ribeira Paul on Santo Antão, and Ribeira Fajã on São Nicolau. These projects are dependent on enhanced availability of water resources through additional rainfall catchment infrastructure and/or ground-water development. Artificial recharge of ground water is being planned as a mitigation strategy to offset the potential of declining aquifer water levels and/or deteriorating water quality associated with increased use. An important metric for the success of the agricultural development projects is the identification of current ground-water baseline conditions in order to evaluate any long-term changes in ground-water resources or water quality.

The U.S. Geological Survey (USGS) received support from the MCC to provide training in ground-water data collection and to assess the current (2005-06) baseline ground-water conditions in the three project basins. Ground-water conditions include ground-water levels, ground-water recharge altitudes and sources, ground-water discharge quantities, ground-water age (residence time), and ground-water quality. These tasks were accomplished, in coordination with the Instituto Nacional de Gestão dos Recursos Hídricos (INGRH), during and after two technical missions to Cape Verde.

\section{Purpose and Scope}

The purpose of this report is to summarize and interpret the ground-water data collected during the project. In addition to this report, ground-water monitoring equipment, training classes and manuals, and field demonstrations were provided in all three study basins. Because of the scarcity of observation wells within each basin and the inability to drill additional wells within the scope of this project, sparse water-level data were combined with other techniques to evaluate ground-water conditions. These other methods include (1) the use of pressure transducers and historical ground-water levels to evaluate temporal changes in potentiometric surfaces in each basin, (2) the measurement of well withdrawals, spring discharge, and gallery drainage in order to estimate ground-water discharge budgets for each basin, and (3) the use of environmental tracers to evaluate sources of aquifer recharge, flow paths, and ground-water residence times.

\section{Acknowledgments}

The authors thank Sra. Elsa Samoes, Millennium Challenge Account Cape Verde, for providing historical precipitation data and artificial recharge development plans; Sra. Maria Modesto, Ministereo de Infrastructuras, Transportes, e Mar, Cape Verde, for providing GIS topographic coverages; Tony Mulhern and Kayo Shiraishi, U.S. Peace Corps volunteers in Santo Antão, for collecting precipitation samples and providing translating assistance during the USGS missions; D. Kip Solomon and Alan Rigby, University of Utah Dissolved-Gas Service Center, for their laboratory analysis and interpretive assistance with dissolved-gas samples; Keith Halford and Edwin Weeks, USGS, for their assistance with interpreting the Galleria Fajã aquifer drawdown data; Patrick Tucci, Richard Healy, and Steven Gingerich, USGS, for technical support; and Lourdes Lima, Instituto Nacional de Gestão dos Recursos Hídricos, Cape Verde, for overseeing in-country logistical support and technical assistance

\section{General Conceptual Model of Volcanic Island Hydrogeology}

Cape Verde consists of a chain of volcanic islands believed to have been formed over an oceanic hot spot (Lodge and Helffrich, 2006). The islands are predominantly basaltic layered lava flows interspersed with pyroclastics and breccias 


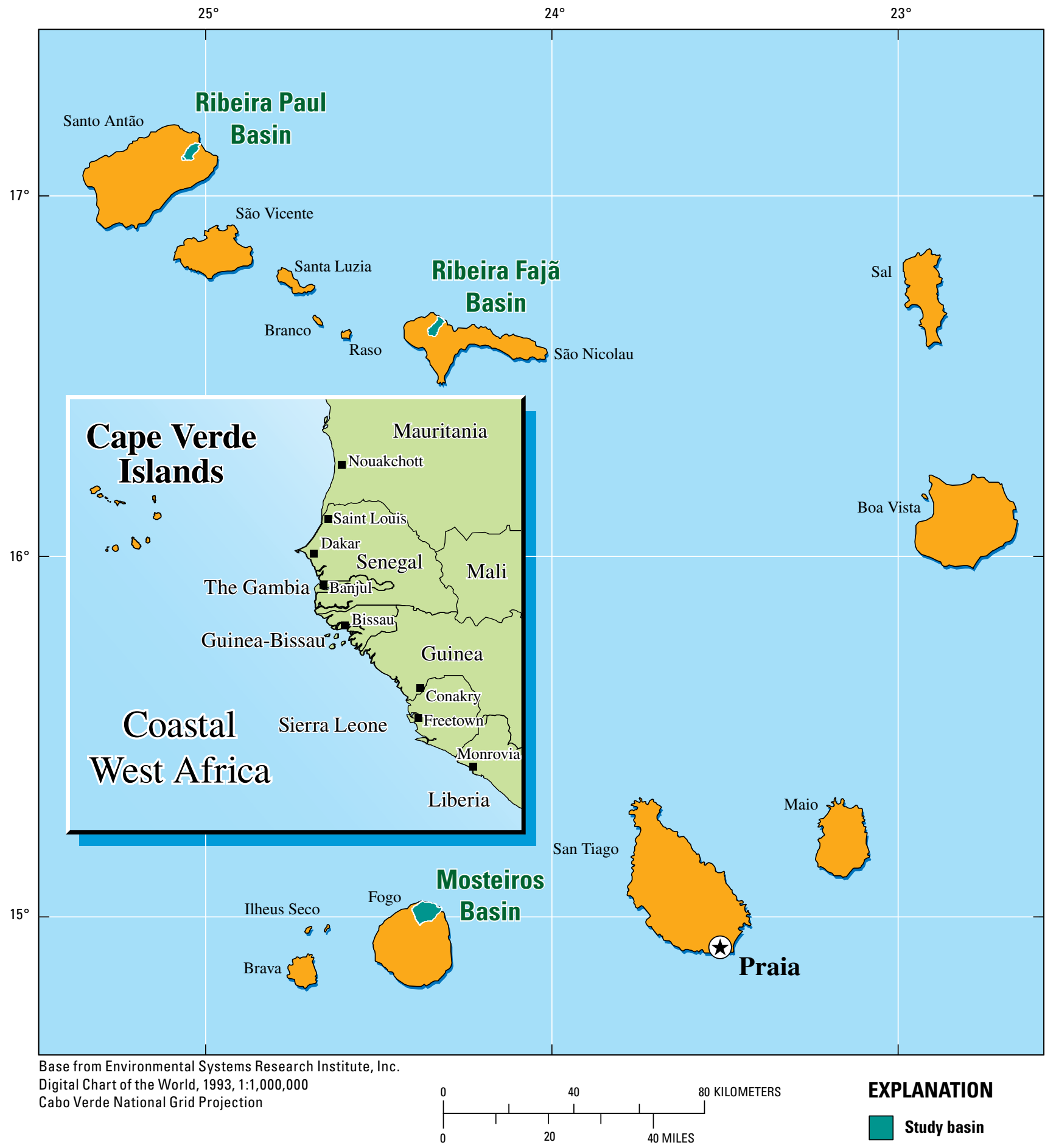

Figure 1. Location of the study basins within the Republic of Cape Verde, West Africa. 
and intruded by near-vertical mafic dikes (Barmen and others, 1990). Volcanic islands, especially those recently formed like Cape Verde, typically have high topographic relief, shallow soils, and rapid runoff. Rainfall distribution and infiltration is dependent upon basin altitude and morphology, orientation with respect to the tropical trade winds, strength of monsoonal patterns, and the thickness and type of soil cover. As is common on most islands with much topographic relief, the islands of Cape Verde typically have wet and dry sides that result from wind and precipitation patterns. In general, however, most infiltration occurs in the higher-altitude parts of the islands, where precipitation rates are highest. Part of this moisture is subsequently lost as either evapotranspiration or lateral flow to perched springs. The component of infiltration that continues downward to recharge the aquifer is herein referred to as net infiltration. Water-table altitude and slope of this aquifer would generally be dependent on both aquifer permeability and net infiltration (recharge) rate. Hydraulic conductivity of basalt is reported to range from about 0.1 to $1,000 \mathrm{~m} / \mathrm{d}$ (Freeze and Cherry, 1979). Studies from Hawaii indicate that highly transmissive volcanic island basalts generally have hydraulic-conductivity values of about 100 to $1,000 \mathrm{~m} / \mathrm{d}$ (Gingerich and Voss, 2002), whereas low-transmissivity basalts generally have hydraulic-conductivities of about 0.1 to $10 \mathrm{~m} / \mathrm{d}$ (Izuka and Gingerich, 2003). Watersheds with high recharge rates and/or low permeability basalt aquifers would have steeper water-table slopes and higher-altitude water tables; watersheds with low net-infiltration rates and/or high permeability basalt aquifers would have lesser slopes, with water tables only a few meters above sea level. Relatively high horizontal hydraulic-conductivity values (hundreds of meters per day) are often reported for basaltic volcanic islands (Prada and others, 2005) and result in a regional (basal) water table within tens of meters of sea level. Low-permeability intrusive mafic dikes, where present, are thought to act as horizontal flow barriers. Similarly, low-permeability breccias, tuffs, and pyroclastics may act as either horizontal or vertical flow barriers. Horizontal and vertical flow barriers may cause perched ground water, high-altitude springs, and/or ground-water compartmentaliza- tion resulting in a stepped (rather than smooth) overall water table (fig. 2)

Measurable ground-water discharge from volcanic island watersheds typically includes discharge to springs, well withdrawals, seepage to streams, and evapotranspiration in areas of shallow water table. Also, in Cape Verde and some other volcanic islands, horizontal tunnels have often been constructed to drain ground water as an additional water-supply source. Ground-water discharge, however, is often dominated by submarine outflow, which is difficult to quantify. Submarine discharge has been documented in other volcanic island sites (Izuka and Gingerich, 2003; Prada and others, 2005) and quantified in other settings (Bokuniewicz, 1980; Cable, 1997; Cambareri and Eichner, 1998; Michael and others, 2003).

Small islands typically have a freshwater lens of ground water (lower density) floating on top of higher-density brackish and salt water. The fresh water/brackish water boundary is not fixed or sharp; rather it is controlled by pressure and density and dependent upon the balance between ground-water recharge and ground-water discharge. Aquifer drawdown associated with excessive pumping, therefore, may lower water levels in the aquifer and move the fresh/brackish water boundary inland, causing salt-water intrusion.

\section{Methods}

\section{Ground-Water Level Data}

In order to evaluate ground-water conditions and provide a baseline for the future assessment of changes in groundwater storage in the three study basins, ground-water levels were measured periodically with electric tapes. In addition, pressure transducers and data loggers were installed in selected observation wells to provide a continuous record of water-level changes.

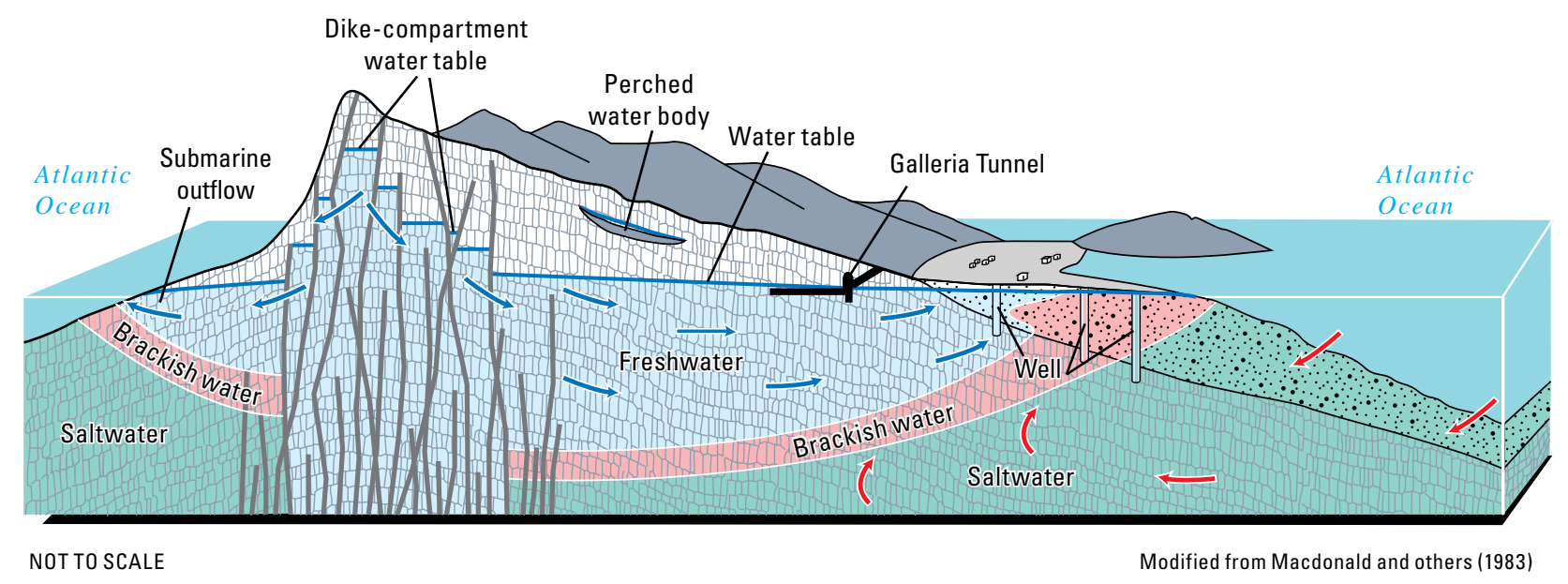

Figure 2. Generalized conceptual model of volcanic island hydrogeology. 


\section{Electric-Tape Measurements}

Manual water-level measurements in production and observation wells were made by the INGRH and the USGS with calibrated electric tapes in all three project basins. The accuracy of this method is about $0.01 \mathrm{~m}$, which is of sufficient precision to provide a baseline for monitoring both seasonal and longer-term water-level changes. Three lengths of electric water-level tapes (60-, 100- and 250-m) were used, depending on the depth to water at each well. Water-level measurements were corrected by subtracting the distance from the measuring point above land surface. Land-surface altitudes were estimated with hand-held GPS, topographic maps, or from drillers' logs. Although the accuracy of these altitudes is only about plus or minus $10 \mathrm{~m}$, this study was concerned with relative depth below land surface and temporal changes in groundwater levels, rather than absolute altitude.

\section{Pressure-Transducer Measurements}

Two types of pressure transducers, vented and nonvented, and data loggers were installed in observation wells to continuously monitor water levels. A vented transducer was installed in observation well FA93 in the Ribeira Paul Basin. These transducers are vented to the atmosphere and automatically compensate for changes in atmospheric pressure. They do not require barometric pressure corrections, but have a fixed-length cable that cannot be modified. Non-vented transducers were installed in observation wells FF07 in the Mosteiros Basin and FN39 in the Ribeira Fajã Basin. The nonvented transducers require independently measured barometric pressure data in order to correct for changes in atmospheric pressure; thus loggers also were installed in FF07 and FN39 to record barometric pressure. The non-vented transducers hang on a small-diameter steel cable rather than requiring a fixedlength cable and, therefore, are better suited for wells with large depths to water and/or where sharp objects in the well may damage the more-delicate vented cable. All the transducers were programmed to record water-pressure and barometric pressure or water-level data every 6 hours, which was later corrected for instrument drift based on independent electrictape water-level measurements (Freeman and others, 2004).

Because of both ocean and earth tides and the relatively small daily absolute water-level change, tidal effects were corrected in two of the four transducer wells. The tidal corrections were done with a digital Butterworth filter program (Umari, M.J., and Earle, J.D., U.S. Geological Survey, written commun., 2002) using a low pass cutoff frequency of 0.8 cycles per day. This is based on frequencies of tidal harmonic components ranging from 0.85 to 2 cycles per day (Merritt, 2004).

\section{Water-Quality Data}

Field parameters were measured and laboratory analysis of environmental tracers was conducted on water samples collected from springs, wells, streams, and tunnels in the three study basins. This information is used for evaluating sources of recharge, ground-water residence times, ground-water flow paths, and salt-water intrusion. It will also provide a baseline geochemical data set for potential evaluation of future changes to the ground-water systems.

\section{Field Parameters}

Field water-quality parameters were measured at groundwater and surface-water sites according to USGS procedures (Wilde and Radtke, 1998). Parameters include specific conductance, $\mathrm{pH}$, temperature, dissolved oxygen, barometric and total dissolved-gas pressure. These parameters were measured with a multimeter probe, which was calibrated daily to a representative set of standards.

Specific conductance was used as a proxy for dissolvedsolids concentration because geochemical laboratory analysis of dissolved solids was not within the scope of this study. Dissolved-solids concentration is generally about 55 to 75 percent of the specific-conductance value, depending on the chemical makeup of the water (Hem, 1992). The $\mathrm{pH}$ of a water sample is often indicative of the movement of ground water through differing geologic layers, such as volcanic or alluvial deposits. Low $\mathrm{pH}$ values may indicate geothermal water sources. Water temperature also is useful for evaluating the influence of upwelling geothermal waters and is needed for the dissolved-gas solubility calculations used in determining recharge temperatures and for tritium/helium age dating. Dissolved oxygen is an indicator of oxidation conditions within an aquifer, including both anaerobic and aerobic bacterial activity associated with the decomposition of organic matter. Barometric and total dissolved-gas pressures are used to guide appropriate dissolved-gas sampling methods and are needed for the determination of absolute dissolved-gas concentrations from in-situ diffusion samplers. Total dissolved gas pressures can also be used to evaluate hydrologic processes such as denitrification, anaerobic decay and gas production $\left(\mathrm{CH}_{4}, \mathrm{H}_{2}\right.$, $\left.\mathrm{CO}_{2}\right)$, degassing of deep geothermal fluids $\left(\mathrm{CO}_{2}\right.$ production $)$, and air entrapment in the recharge zone.

\section{Environmental Tracer Analyses}

Ground-water samples were analyzed for the stable (deuterium and oxygen-18) isotopes of the water molecule. Samples for deuterium $\left({ }^{2} \mathrm{H}\right)$ and oxygen-18 $\left({ }^{18} \mathrm{O}\right)$ were collected from open boreholes by using polyvinyl chloride 1,000$\mathrm{ml}$ sample bailers. Water samples from production wells were collected by using existing submersible pumps. Water samples from springs and tunnels were collected by gravity flow. Stable-isotope samples were collected according to procedures 
described by Coplen and others (1996), stored in clean polyethylene bottles, and analyzed by the USGS Stable Isotope Laboratory in Reston, Virginia. The stable isotopes $\left({ }^{2} \mathrm{H},{ }^{18} \mathrm{O}\right)$ are used to evaluate the relative altitude of source precipitation that recharges a ground-water system. These stable isotopes are analyzed by measuring the ratio of the heavier, less-abundant isotope to the lighter, more-abundant isotope and are reported as differences to a known standard. The isotope ratios are reported as delta $(\delta)$ values expressed as parts per thousand (permil). The $\delta$ value for an isotope ratio, $\mathrm{R}$, is determined by:

$$
\delta R=\left(R_{\text {sample }} / R_{\text {standard }}-1\right) \times 1000
$$

where:

$\delta R$ is the $\delta$ value for a specific isotope in the sample $\left({ }^{2} \mathrm{H}\right.$ or $\left.{ }^{18} \mathrm{O}\right)$,

$R_{\text {sample }}$ is the ratio of the rare isotope to the common isotope for a specific element in the sample, and

$R_{\text {standard }}$ is the ratio of the rare isotope to the common isotope for the same element in the standard reference material.

A positive $\delta R$ value indicates that the sample is enriched in the heavier isotope with respect to the sample. A negative $\delta \mathrm{R}$ value indicates that the sample is depleted in the heavier isotope with respect to the sample. In general, precipitation falling at a higher altitude is more isotopically depleted in ${ }^{2} \mathrm{H}$ and ${ }^{18} \mathrm{O}$ than precipitation at lower altitudes. Therefore, these stable isotopes are generally helpful for evaluating the precipitation source areas of recharge to an aquifer (Mazor, 1991). The relation between $\delta^{2} \mathrm{H}$ and $\delta^{18} \mathrm{O}$ values generally plots along a trend line known as the global meteoric water line. This trend is described by the equation:

$$
\delta^{2} H=8\left(\delta^{18} O\right)+d
$$

where:

$d \quad$ is defined as the ${ }^{2} \mathrm{H}$ excess (Dansgaard, 1964). The mean global value for $d$ in freshwater is 10 (Craig, 1961).

Dissolved-gas samples were collected to evaluate ground-water recharge temperature (temperature of water entering the water table). In contrast to stable isotopes, these tracers are useful for evaluating the altitude where recharge actually enters the aquifer rather than the altitude where the precipitation occurs. A large fraction of gases dissolved in ground water originate in the atmosphere and their solubility in water is temperature-dependent (Stute and Schlosser, 2001). As recharging water enters an aquifer, these dissolvedgas concentrations are "locked in" based on the temperature, barometric pressure, amount of excess air, and salinity at the water table (Aeschbach-Hertig and others, 1999; Ballentine and Hall, 1999; Stute, 2001). Because the gases are relatively inert, their concentrations generally remain unchanged along ground-water flow paths to points of discharge (wells and springs). Dissolved-gas concentrations in discharging ground water, therefore, can be used to estimate ground-water recharge temperatures. For this study, dissolved concentrations of $\mathrm{N}_{2},{ }^{40} \mathrm{Ar},{ }^{84} \mathrm{Kr},{ }^{20} \mathrm{Ne}$, and ${ }^{129} \mathrm{Xe}$ were used in the closed system equilibration model (Aeschbach-Hertig and others, 2000; Kipfer and others, 2002) to calculate estimated ground-water recharge temperature, pressure, excess air, and a fractionation factor (related to the partial dissolution of trapped air bubbles). Because there are five known parameters (the individual dissolved-gas concentrations) and four unknowns, this is an over-determined problem that can be solved (optimized) with a system of linear equations.

Dissolved-gas samples were collected as water samples in copper tubes and as gas samples with in-situ diffusion samplers. The copper-tube collection method for dissolved gases is described by Stute and Schlosser (2001). The diffusion sampler method is described by Sheldon (2002). The diffusion sampler consists of a small copper chamber (about 0.82 $\mathrm{cm}^{3}$ ) with gas-permeable membranes. Samplers were installed in wells and springs and allowed to equilibrate with the water for 24 hours. The samples were quickly removed and coldwelded by using a pinch-off tool. Dissolved-gas concentrations were analyzed by the University of Utah's Dissolved Gas Service Center using both quadrapole and sector-field mass spectrometers. The mass-spectrometer analysis provides the relative mole fractions of dissolved gases. The dissolved-gas concentrations of the water sample are then calculated based on Henry's Law relations by using field measurements of total dissolved-gas pressure and water temperature. The University of Utah's analytical precision generally results in a $\pm 0.5^{\circ} \mathrm{C}$ uncertainty in dissolved-gas recharge temperatures for samples with small amounts of excess air and known recharge altitude (K. Solomon, University of Utah, oral commun., 2006).

Recharge altitude is an unknown parameter, a typical situation in locations with high topographic gradient, such as the three study basins in Cape Verde. Because recharge temperature and recharge altitude are correlated, it is common to generate a range of estimated dissolved-gas recharge temperatures for each ground-water sample using (1) the landsurface altitude (the minimum altitude where recharge could occur) at each sample site to calculate a maximum dissolvedgas recharge temperature $\left(\operatorname{Tr}_{\text {max }}\right)$, and (2) the highest possible water-table altitude (the maximum altitude where recharge could occur) within the watershed to calculate a minimum dissolved-gas recharge temperature $\left(\operatorname{Tr}_{\text {min }}\right)$. This possible range of dissolved-gas recharge temperatures for each sample is then compared to the atmospheric temperature lapse curve to determine the "most-probable" dissolved-gas recharge temperature and recharge altitude.

Temperature lapse rates vary at different locations. Factors affecting temperature lapse rates include strength of solar radiation (season, slope, aspect), proximity to oceans, topography (cold air drainage), and relative humidity. Air temperature lapse rates are generally about $-6^{\circ} \mathrm{C}$ per $1,000 \mathrm{~m}$ (Rolland, 2003), but can vary from $-10^{\circ} \mathrm{C}$ per $1,000 \mathrm{~m}$ (dry air adiabatic lapse rate) to $-4^{\circ} \mathrm{C}$ per $1,000 \mathrm{~m}$ (saturated adiabatic lapse rate). Water-table temperature lapse rates are assumed 
to be similar to air temperature lapse rates in places having shallow depth to water and can be generated from measurements of spring altitude and water temperature (Manning and Solomon, 2003). However, if there is a thick vadose zone and large depth to water, the apparent temperature lapse rate may be lower because of the geothermal gradient. Therefore, apparent recharge altitudes derived from dissolved-gas recharge temperatures in this study are likely a minimum and may underestimate actual recharge altitudes towards the interior of the islands where there is the possibility of a thick vadose zone and deep water table.

A local temperature lapse rate for Cape Verde was constructed based on the relation between altitude and measured water temperature for seven springs within the three study basins, as well as other published data. These published data include 10 springs in Fogo but outside the Mosteiros Basin study area (Kallrén and Schreiber, 1988; Barmen and others, 1990) and 34 springs on the island of Santiago (Barmen and others, 1984). In order to minimize the influence of geothermally affected waters, only springs with water temperatures of $<26^{\circ} \mathrm{C}$ were used when constructing the lapse curve. Spring altitude and water temperature are closely correlated $\left(\mathrm{r}^{2}=\right.$ 0.75 ; fig. 3 ). The resulting temperature lapse rate is about $-5^{\circ} \mathrm{C}$ per $1,000 \mathrm{~m}$. This lapse rate is within the reported range in lapse rates (Rolland, 2003). The following relation can be used for estimating water-table temperature lapse rate (fig. 3):

$$
A=(24.3-T) / 0.005
$$

where:

$$
\begin{gathered}
A \quad \text { is altitude, in } \mathrm{m}, \text { and } \\
T \quad \text { is temperature, in }{ }^{\circ} \mathrm{C} .
\end{gathered}
$$

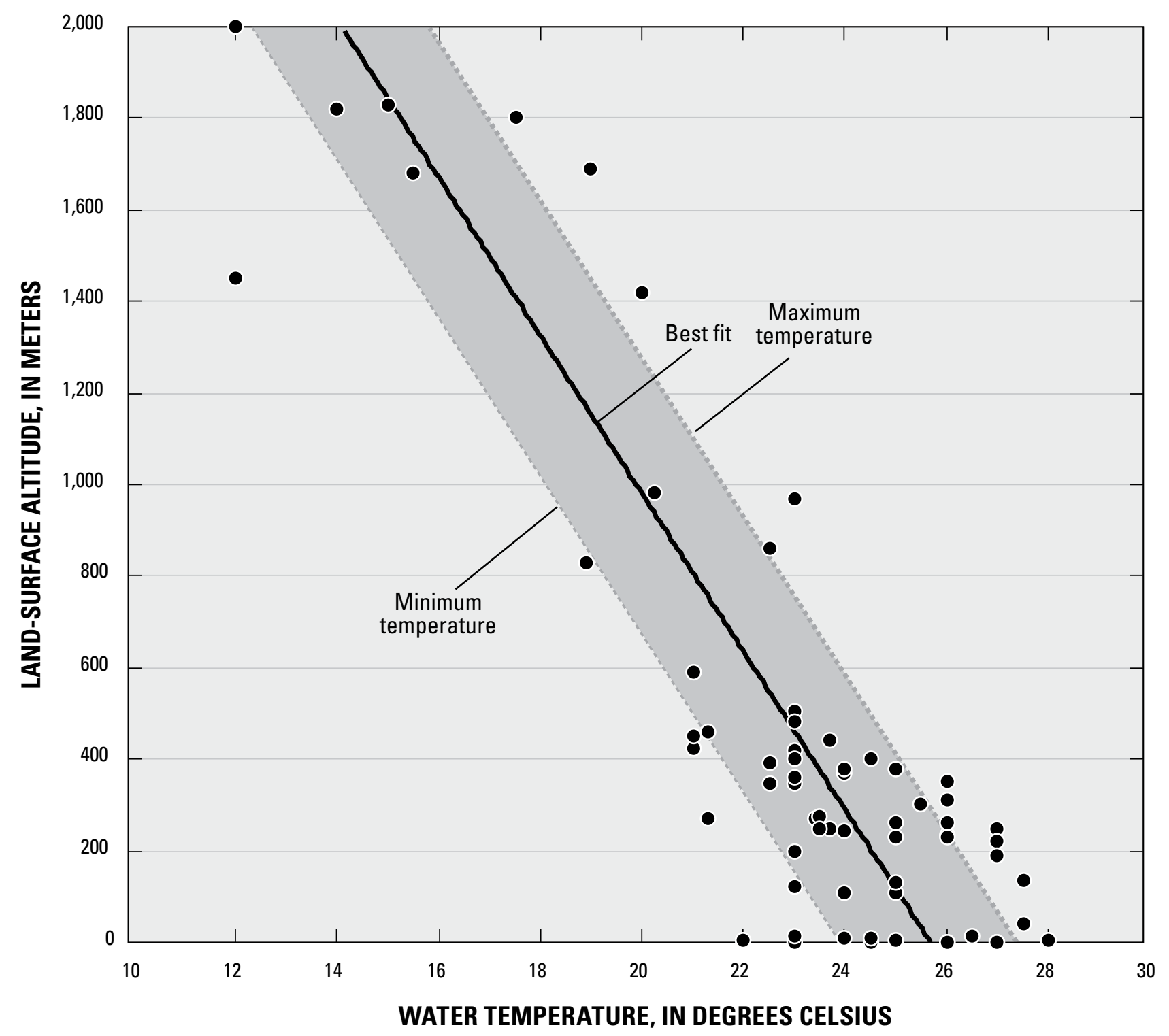

Figure 3. Relation between land-surface altitude and water temperature for springs in Cape Verde. 
Because of uncertainty in the measured temperature lapse curve, it is often presented as a band of altitude-dependent temperatures. Residuals calculated by subtracting the measured temperature from the theoretical temperature for each spring by using equation 3 result in a standard deviation of $1.6^{\circ} \mathrm{C}$. A 2-sigma temperature band of $3.2^{\circ} \mathrm{C}$ for each altitude was used, therefore, in order to encompass 95 percent of the samples.

The "most probable" range of recharge temperature/altitude combinations is then determined by the intersection of the maximum range of recharge temperatures $\left(\operatorname{Tr}_{\min } / \operatorname{Tr}_{\text {max }}\right)$ and the temperature lapse band. Estimated recharge altitudes have an uncertainty that is difficult to quantify, caused primarily by uncertainty in the temperature lapse rate.

Ground-water samples also were collected and analyzed for the tritium $\left({ }^{3} \mathrm{H}\right)$ isotope in the water molecule. As with the stable isotopes, ${ }^{3} \mathrm{H}$ samples were collected from open boreholes by using polyvinyl chloride 1,000-ml sample bailers. Water samples from production wells were collected by using existing submersible pumps. Water samples from springs and tunnels were collected by gravity flow. All samples were stored in clean polyethylene bottles. Tritium samples were analyzed with the tritium in-growth method (Clarke and others, 1976) at the University of Utah's Dissolved Gas Service Center.

Tritium is a radioactive isotope of hydrogen and decays to tritiogenic helium $\left({ }^{3} \mathrm{He}_{\text {trit }}\right)$ with a half life of 12.3 years and, therefore, can be used for evaluating the relative age of ground water. As with the stable isotopes, tritium is analyzed by measuring the ratio of the heavier and less-abundant isotope to the lighter and more-abundant isotope. Tritium concentrations are reported in tritium units, where one tritium unit represents one molecule of ${ }^{3} \mathrm{H}^{1} \mathrm{HO}$ in $10^{18}$ molecules of ${ }^{1} \mathrm{H}_{2} \mathrm{O}$ (Solomon and Cook, 2000). Tritium is naturally produced in earth's upper atmosphere through cosmic-ray neutron bombardment of nitrogen. Much larger amounts were introduced into the atmosphere during thermonuclear testing in the 1950s and 1960s. On the basis of International Atomic Energy Agency records from network stations at similar latitudes (Barbados, Ascension Island, St. Helena), Barmen and others (1990) estimated that the natural background concentration of ${ }^{3} \mathrm{H}$ in precipitation in Cape Verde was about 4 TU prior to 1953 and after 1980. This conclusion is consistent with five precipitation samples collected on Santiago Island during 1984 with ${ }^{3} \mathrm{H}$ concentrations ranging from $2.3 \pm 0.1$ to $4.4 \pm 0.2 \mathrm{TU}$ (Akiti, $1985)$ and one sample collected on Fogo Island in 1987 with a ${ }^{3} \mathrm{H}$ concentration of $3.0 \pm 1 \mathrm{TU}$ (Barmen and others, 1990). The samples collected during the 1980s, however, may still have contained some anthropogenic ${ }^{3} \mathrm{H}$. Sampling during 2005, as part of this study, indicates a current atmospheric concentration of 1 to $3 \mathrm{TU}$, which may be a more accurate natural background concentration for Cape Verde. Relatively large amounts of anthropogenic ${ }^{3} \mathrm{H}$ were introduced into the atmosphere by thermonuclear testing in the 1950s and 1960s, with estimated peak precipitation ${ }^{3} \mathrm{H}$ concentrations in Cape
Verde reaching about 175 TU in 1964 (Kallrén and Schreiber, 1988).

Based on its 12.3-year half life, decay-corrected ${ }^{3} \mathrm{H}$ concentrations can be calculated with:

$$
C=C_{o} e^{-t \lambda}
$$

where:

$C$ is the measured ${ }^{3} \mathrm{H}$ concentration in water,

$C_{o}$ is the initial ${ }^{3} \mathrm{H}$ concentration,

$t$ is the number of years since the precipitation occurred, and

$\lambda$ is the decay constant $\left(0.0565 / \mathrm{yr}\right.$ for $\left.{ }^{3} \mathrm{H}\right)$.

The estimated initial and decay-corrected ${ }^{3} \mathrm{H}$ concentration of precipitation in Cape Verde from 1950 through 2005, modified from Barmen and others (1990), is shown in figure 4. Assuming that precipitation recharging aquifers in Cape Verde prior to the early 1950 s had an initial ${ }^{3} \mathrm{H}$ concentration of 3.0 TU, these waters in 2005 would have had a ${ }^{3} \mathrm{H}$ concentration of $\leq 0.3$ TU. Recharge that occurred during above-ground nuclear testing in the late 1950s and 1960s (assuming initial ${ }^{3} \mathrm{H}$ concentrations in precipitation of 10 to $175 \mathrm{TU}$ ) would have current ${ }^{3} \mathrm{H}$ concentrations of about 1 to 17 TU. Water recharging the aquifer during the 1970s (assuming initial ${ }^{3} \mathrm{H}$ concentrations in precipitation of 4.0 to $14 \mathrm{TU}$ ) would have current ${ }^{3} \mathrm{H}$ concentrations between 0.6 and 2.0 TU. Water recharging the aquifer during the 1980s (assuming an average ${ }^{3} \mathrm{H}$ concentration in precipitation of $3.5 \mathrm{TU}$ ) would have current ${ }^{3} \mathrm{H}$ concentrations between 0.9 to $1.4 \mathrm{TU}$. Water recharging the aquifer during the 1990s to present (assuming an average ${ }^{3} \mathrm{H}$ concentration in precipitation of about 2.0 to 3.0 TU) would have current ${ }^{3} \mathrm{H}$ concentrations between 1.4 and 3.0 TU. Ground water discharging from springs and wells often contains a mixture of flow paths having water of various ages. Ground water having a ${ }^{3} \mathrm{H}$ concentration less than $4 \mathrm{TU}$ but greater than $0.3 \mathrm{TU}$ may represent a mixture of both young and old waters rather than representing a discrete flow path and recharge year. Except for ground-water recharge occurring during the $1963{ }^{3} \mathrm{H}$ peak, therefore, it is generally not possible to uniquely determine modern (post-1950s) ground-water ages from tritium alone.

Tritium/helium $\left({ }^{3} \mathrm{H} /{ }^{3} \mathrm{He}_{\text {trit }}\right)$ age dating is a technique, however, that can be used for dating relatively young ground water recharged within the past 50 years. ${ }^{3} \mathrm{H}$ in the water molecule decays to ${ }^{3} \mathrm{He}_{\text {trit }}$, a gas which is readily lost in the atmosphere but is geochemically conservative (inert) when dissolved in ground water. The age-dating clock begins, therefore, when recharge crosses the water table rather than when it infiltrates the subsurface. The ${ }^{3} \mathrm{H} /{ }^{3} \mathrm{He}_{\text {trit }}$ ratio can be used to determine the number of years since the water entered the aquifer as recharge with the following equation:

$$
t=\lambda^{-1} \ln \left({ }^{3} \mathrm{He} e_{\text {trit }} /{ }^{3} \mathrm{H}+1\right)
$$


where:

$t$ is the apparent age in years, and

$\lambda$ is the ${ }^{3} \mathrm{H}$ decay constant of $0.0563 / \mathrm{yr}$ (Solomon and Cook, 2000).

In areas with thick vadose zones and low recharge rates, this apparent recharge age may underestimate the actual time since the infiltration of precipitation occurred. Also, the apparent age of ground water at sites with convergent flow, such as at springs or wells with large perforated intervals, will be a weighted average age of water traveling along various flow paths. The ${ }^{3} \mathrm{H} /{ }^{3} \mathrm{He}$ trit ratio only yields the age of the modern component of ground water. The ratio of the reconstructed initial ${ }^{3} \mathrm{H}$ concentration in the ground-water sample (sum of ${ }^{3} \mathrm{H}$ plus ${ }^{3} \mathrm{He}_{\text {trit }}$ ) divided by the expected initial ${ }^{3} \mathrm{H}$ concentration in precipitation (fig. 4) yields the modern (post-1950s) fraction of water.

\section{Spring and Stream Discharge Data}

Two methods were used to quantify ground-water discharge to springs and streams. A bucket of known volume (generally $10 \mathrm{~L}$ ) and stopwatch was used for smaller discharge measurements where the flow could be diverted into a freefalling column. A current (pygmy) meter to measure velocity (Buchanon and Somers, 1969) was used for higher discharge rates (greater than $300 \mathrm{~L} / \mathrm{min}$ ) and where the flow could not be diverted to a free-falling column.

\section{Hydrogeologic Setting}

\section{Mosteiros Basin, Fogo}

Mosteiros is the southernmost of the three study basins and is located on the island of Fogo (fig. 1), which has the only active volcano in the archipelago. The island is a relatively new addition to the archipelago, having been formed within the last 500,000 years. Its most recent eruption occurred in 1995. The island is a spherical cone with a peak at 2,900 $\mathrm{m}$, the second tallest point in the Atlantic Ocean.

Because of the island's conical shape, the Mosteiros Basin (fig. 5) is uniquely composed of eight smaller watersheds on the flank of the volcano that each drain directly to the ocean. In contrast, the other two basins (Ribeira Paul and Ribeira Fajã) only consist of one watershed each draining to the ocean. The Mosteiros Basin is also larger than the other two basins, with a total area of $42 \mathrm{~km}^{2}$ (table 1). It has a maximum altitude of $2,400 \mathrm{~m}$, about $1,000 \mathrm{~m}$ higher than the other basins. The average topographic slope of the basin is 27 degrees, steeper than the Ribeira Fajã Basin (23 degrees) but not as steep as the Ribeira Paul Basin (38 degrees).

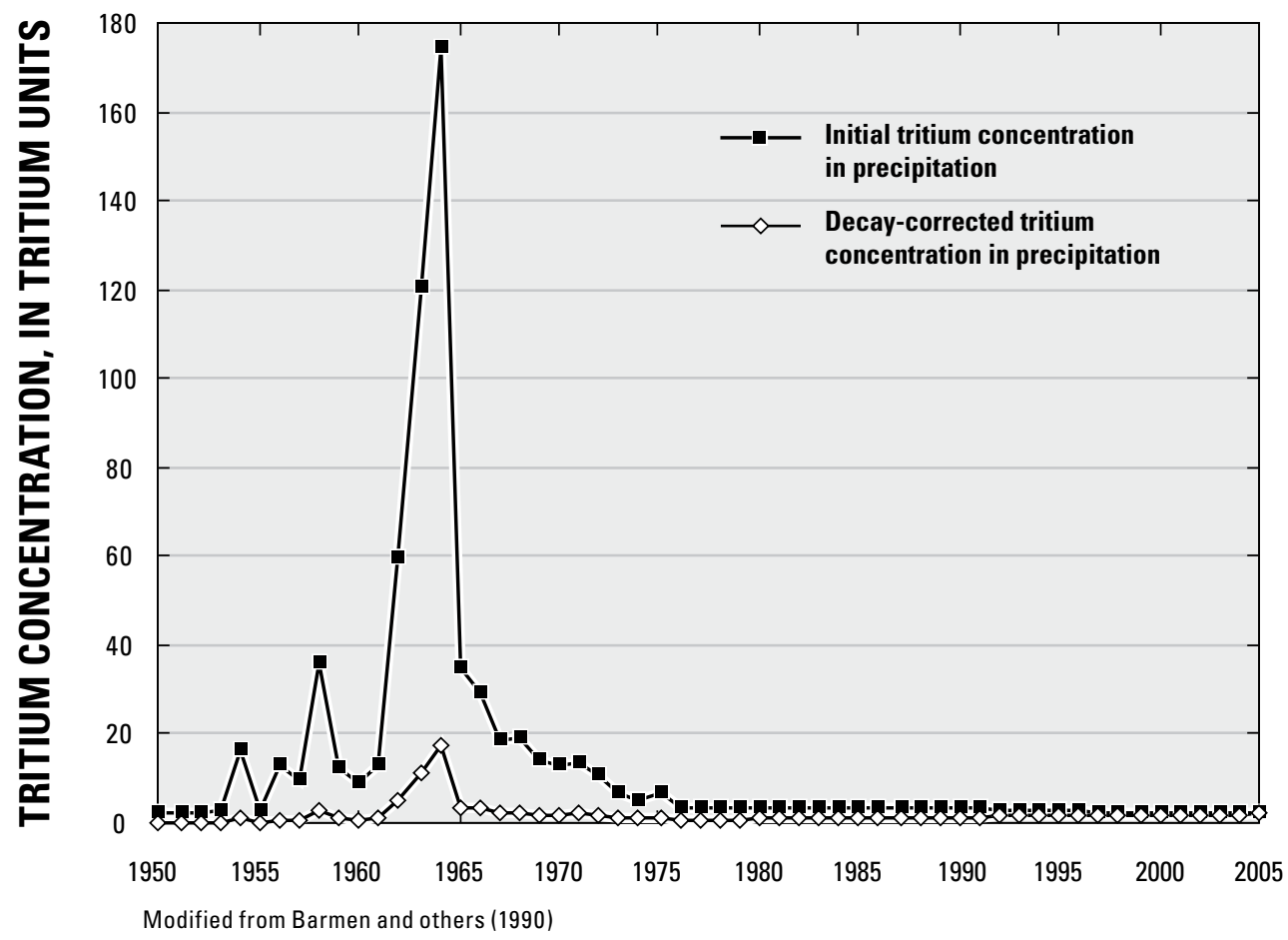

Figure 4. Estimated initial and decay-corrected tritium concentration of precipitation in Cape Verde, 1950-2005. 


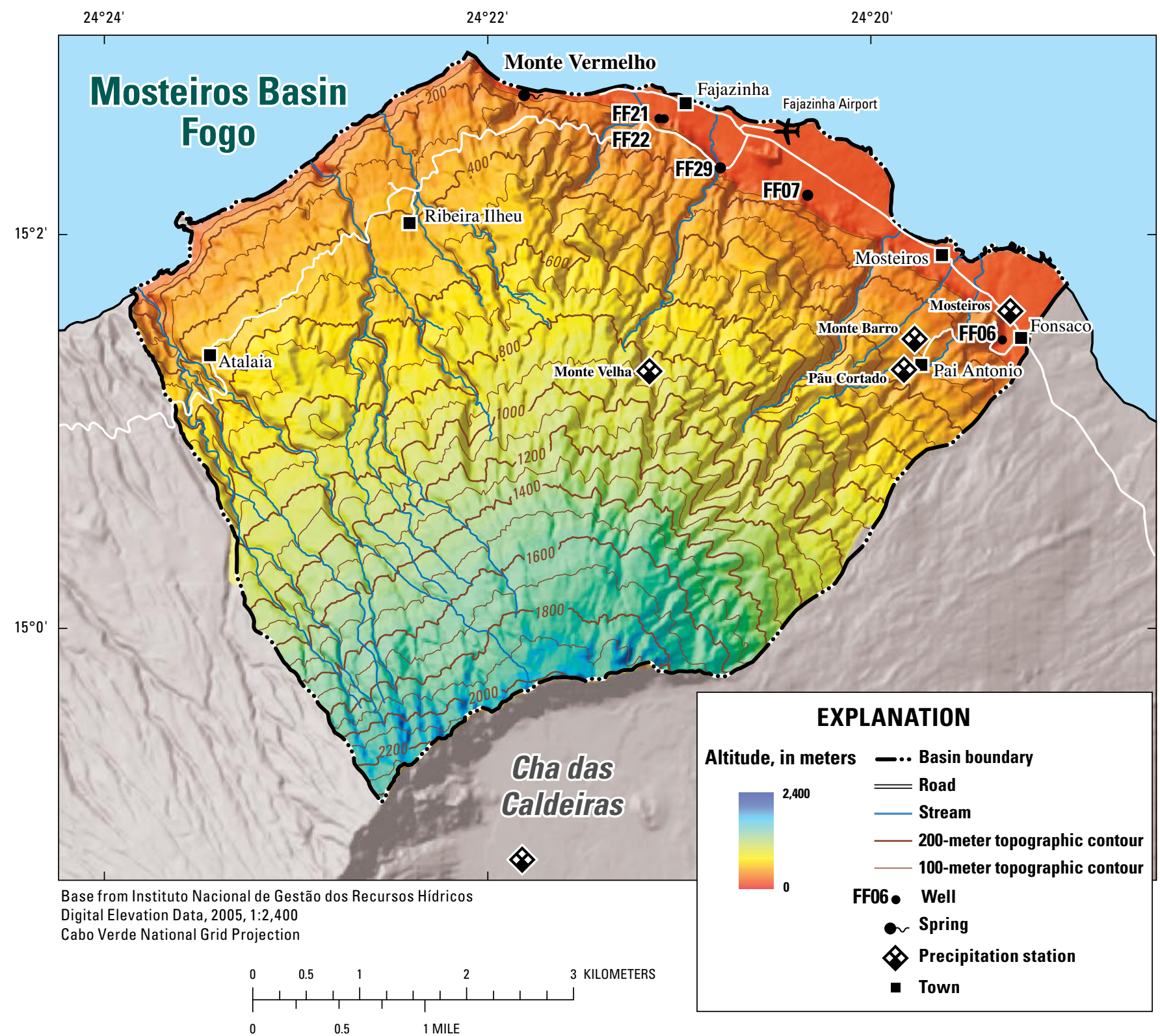

Figure 5. Location of wells, springs, and precipitation stations in the Mosteiros Basin, Fogo, Cape Verde.

Table 1. Area, slope, and average and maximum altitude of the Mosteiros, Ribeira Paul, and Ribeira Fajã Basins, Cape Verde

\begin{tabular}{lcccc}
\hline Basin & $\begin{array}{c}\text { Total area } \\
\text { (square kilo- } \\
\text { meters) }\end{array}$ & $\begin{array}{c}\text { Average } \\
\text { slope } \\
\text { (degrees) }\end{array}$ & $\begin{array}{c}\text { Average } \\
\text { altitude } \\
\text { (meters) }\end{array}$ & $\begin{array}{c}\text { Maximum } \\
\text { altitude } \\
\text { (meters) }\end{array}$ \\
\hline Mosteiros & 42 & 27 & 820 & 2,400 \\
Ribeira Paul & 15 & 38 & 620 & 1,500 \\
Ribeira Fajã & 16 & 23 & 480 & 1,300 \\
\hline
\end{tabular}


The geology of the Mosteiros Basin (fig. 6) is dominated by basaltic lava flows with intercalated pyroclastic deposits (Barmen and others, 1990). The basin is also dotted with numerous cinder cones made of coarse volcanic fragments (lapilli). The basement rocks within the basin consist of an alkaline-carbonatite basaltic complex. Lava flows associated with the basement rocks are highly weathered to clays, presumably acting as a low-permeability barrier. The basement rocks are also cut by a dense network of igneous dikes and contain granular xenoliths, further reducing their permeability.
Basaltic lava flows of the Principal Eruptive Complex overlie these basement rocks. These basalts have prominent columnar jointing (Barmen and others, 1990), as observed along the sea cliffs in the northernmost part of the Mosteiros Basin. Pillow lavas also are associated with these basalts. The basalts are intercalated with both coarse-grained pyroclastic tuffs and thin layers of clays. The lava flows form fairly continuous steeply dipping layers (20 to more than 30 degrees) from the island's central caldera complex (Cha das Caldeiras) to the sea that likely are important conduits of ground-water flow. In addition to columnar jointing, widespread fracturing

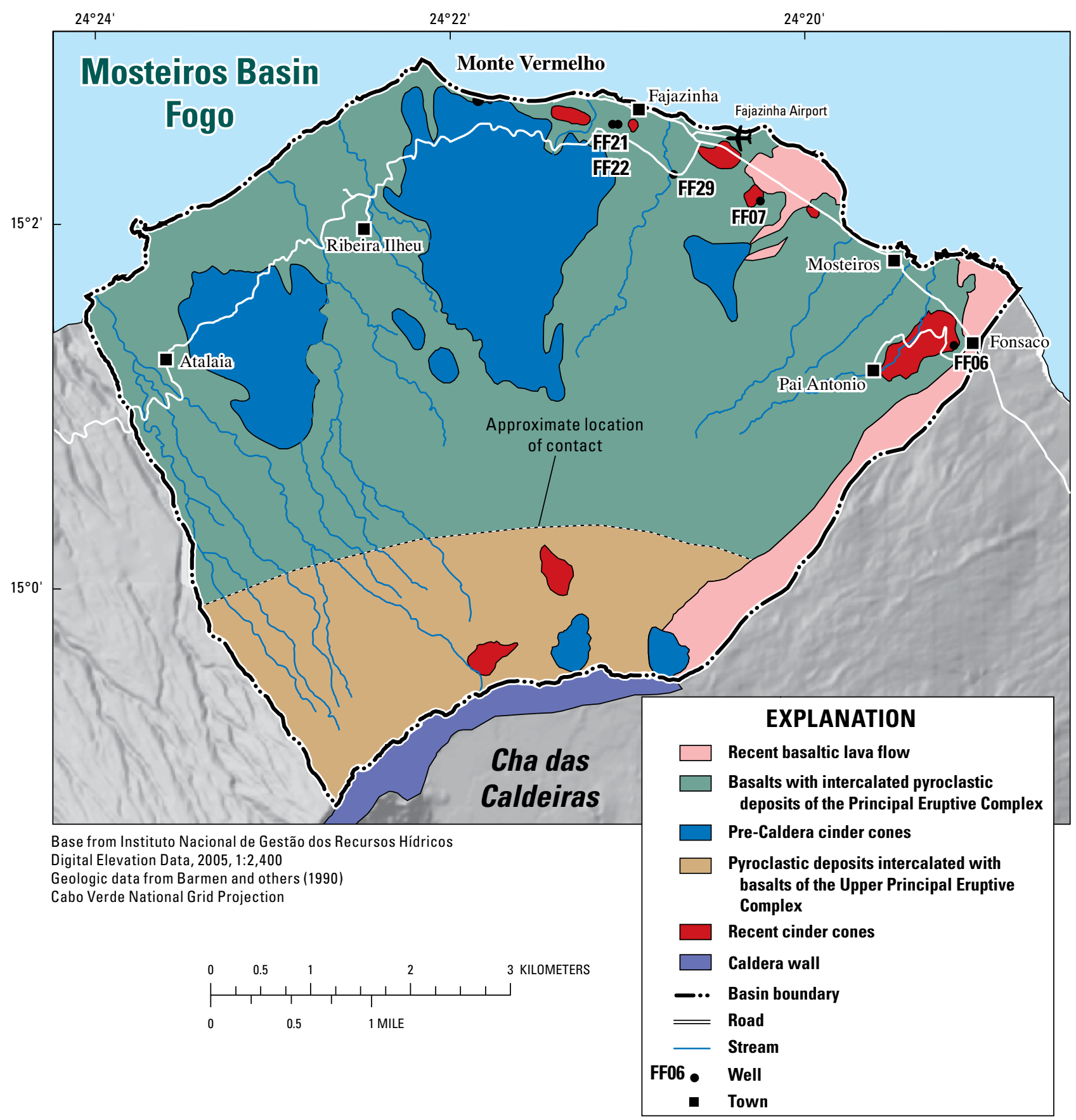

Figure 6. Geology of the Mosteiros Basin, Fogo, Cape Verde. 
also increases the permeability of these basaltic lava flows. In contrast to the basement rocks, the noticeable absence of dikes cutting across the basalts of the Principal Eruptive Complex reduces the likelihood of flow barriers, thus further enhancing the probability of ground-water flow in this layer.

The southern (highest-altitude) part of the Mosteiros Basin is composed of the Upper Principal Eruptive Complex associated with Fogo's upper volcanic cone. In contrast to the prominent lava flows of the Principal Eruptive Complex, this layer is dominated by pyroclastic tuffs, lapilli, and agglomerates and is cut by a dense network of basaltic sills and dikes, which are less transmissive for ground-water flow.

The morphology of the Mosteiros Basin is dominated by the steep slope of the main volcanic cone and numerous recent lava flows and cinder cones (fig. 6). Superimposed on this slope are narrow incised gullies, indicative of the highenergy runoff from sporadic but intense precipitation events. Because of the recent creation of the island and the intensity of runoff, soil layers are generally very thin or non-existent. The exception to this is along the northeastern coast, where volcanic cliffs form a very steep escarpment juxtaposed against a nearly flat coastal plain with rich volcanically derived soils. The southern border of the Mosteiros Basin is defined by the 1,000-m near-vertical wall of the island's 8-km-wide caldera. This feature acts as a prominent surface-water divide. Water falling on the north-facing slope of the caldera wall runs off toward the coastal areas of the Mosteiros Basin; water falling on the south-facing slope drains into the closed basin of the caldera. Because the caldera bottom is covered by highly permeable volcanic deposits (lapilli, scoria, and basalt flows) and receives relatively large amounts of precipitation, this area likely provides a substantial amount of recharge to the island's ground-water system.
Seven-year (1996-2002) average annual precipitation was $207 \mathrm{~mm}$ at the Mosteiros station (75-m altitude), $346 \mathrm{~mm}$ at the Monte Barro station (348-m altitude), and $379 \mathrm{~mm}$ at the Pau Cortado station (460-m altitude) (fig. 5, table 2; Instituto Nacional de Meteorologia e Geofisica, written commun., 2005). These data follow the expected trend of higher precipitation rates at higher altitudes. Although precipitation data for the same 7-year period are not available in the highland areas of the basin, historical data from the Monte Velha station (850-m altitude) and the Cha das Caldeiras station (1,650-m altitude) indicate that annual rainfall exceeds $1,000 \mathrm{~mm}$ in the upper reaches of the basin (Barmen and others, 1990). This precipitation supplies sporadic runoff and flow to gullies, but there are no perennial streams in the basin. The range from 72 to $453 \mathrm{~mm} / \mathrm{yr}$ at Mosteiros (table 2) shows the annual variability in precipitation within the basin.

\section{Ribeira Paul Basin, Santo Antão}

Santo Antão is the northwesternmost island of Cape Verde and the Ribeira Paul Basin is located on its northeastern coast (fig. 1). The basin area, not including the adjacent La Cova closed basin, is $15 \mathrm{~km}^{2}$ (table 1). The basin's vertical relief of $1,500 \mathrm{~m}$ (fig. 7) is much less than that of the Mosteiros Basin; however, it is a more deeply incised basin, as indicated by its higher average topographic slope of about 38 degrees, compared to 23 and 27 degrees for the other two study basins.

As with the Mosteiros Basin, the geology of the Ribeira Paul Basin is dominated by volcanic rocks. In contrast to Fogo, the island of Santo Antão is geologically much older,

Table 2. Annual precipitation at selected stations in the Mosteiros, Ribeira Paul, and Ribeira Fajã Basins, Cape Verde

[Precipitation reported in millimeters]

\begin{tabular}{|c|c|c|c|c|c|c|c|c|c|}
\hline Station name & Mosteiros & $\begin{array}{c}\text { Monte } \\
\text { Barro } \\
\end{array}$ & $\begin{array}{c}\text { Pau } \\
\text { Cortado }\end{array}$ & $\begin{array}{l}\text { Figeuiral } \\
\text { Paul }\end{array}$ & Passagem & Covão & Posto & $\begin{array}{c}\text { Canto } \\
\text { Fajã }\end{array}$ & Cachaço \\
\hline $\begin{array}{l}\text { Altitude } \\
\text { (meters) }\end{array}$ & 75 & 348 & 460 & 200 & 300 & 810 & 410 & 575 & 715 \\
\hline Basin & Mosteiros & Mosteiros & Mosteiros & Paul & Paul & Paul & Fajã & Fajã & Fajã \\
\hline 1996 & 72 & 435 & 207 & 599 & 1054 & 773 & 187 & 251 & 319 \\
\hline 1997 & 149 & 213 & 272 & 246 & 525 & 509 & 237 & 371 & 378 \\
\hline 1998 & 158 & 410 & 366 & 276 & 384 & 409 & 230 & 213 & 296 \\
\hline 1999 & 453 & 504 & 620 & 1,044 & 1,391 & 958 & 430 & 386 & 541 \\
\hline 2000 & 76 & 117 & 196 & 695 & 1,172 & 940 & 366 & 187 & 344 \\
\hline 2001 & 279 & 403 & 731 & 263 & 314 & 438 & 189 & 207 & 352 \\
\hline 2002 & 264 & 339 & 259 & 443 & 658 & 636 & 411 & 501 & 677 \\
\hline 7-year average & 207 & 346 & 379 & 509 & 785 & 666 & 293 & 302 & 415 \\
\hline
\end{tabular}




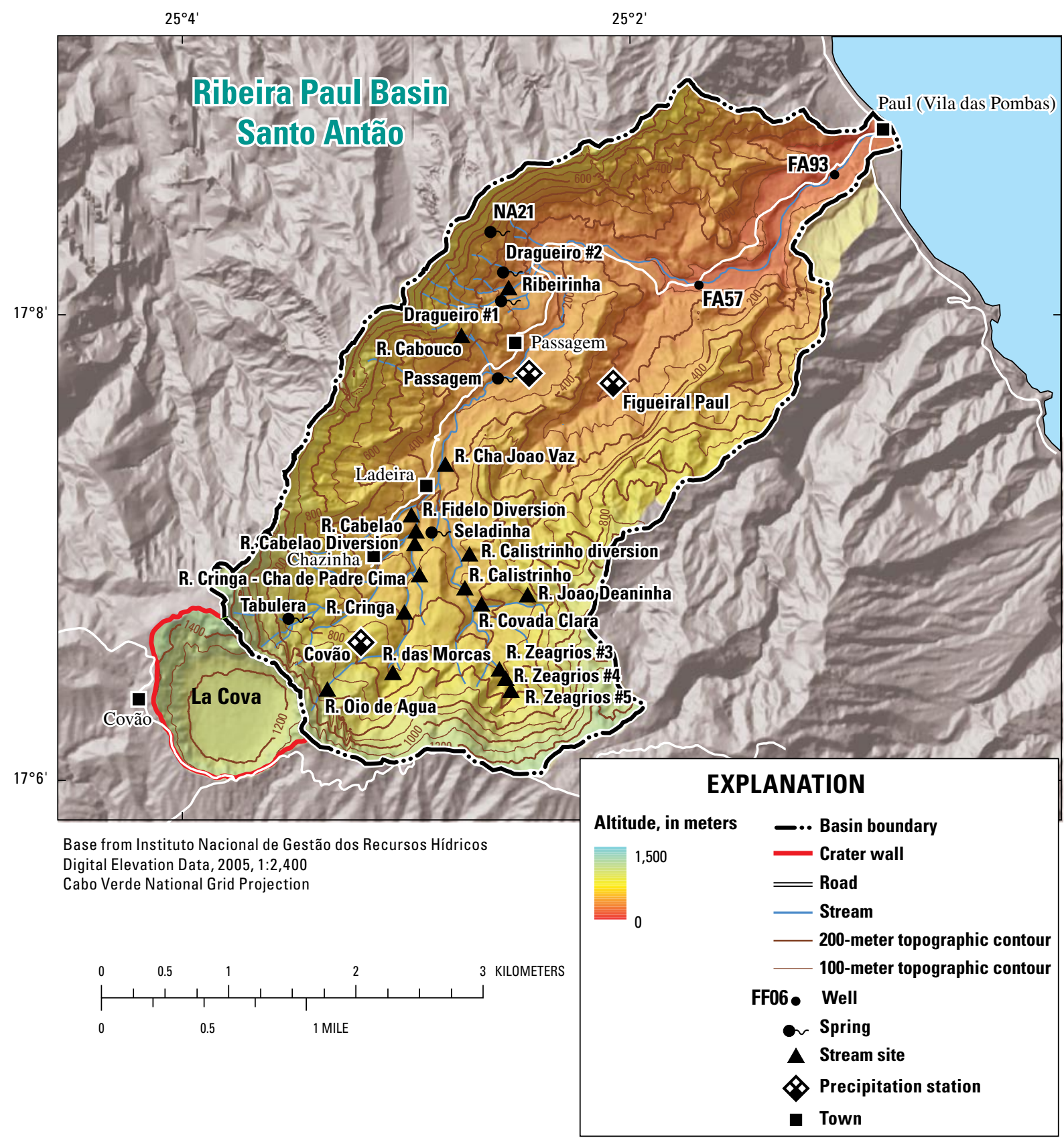

Figure 7. Location of wells, springs, and precipitation stations in the Ribeira Paul Basin, Santo Antão, Cape Verde.

thus there has been more time for erosion to create a welldeveloped canyon system. The predominant exposed rocks within the basin include basaltic lava flows and pyroclastic deposits (fig. 8). Many near-vertical igneous dikes in the basalts are exposed along the upper canyon headwalls. Beneath these rocky headwalls, most of the sloping terrain within the basin has only a veneer of soils. Alluvial deposits thicker than a few meters are only present along the wash at the lower end of Ribeira Paul.

Annual precipitation in the Ribeira Paul Basin is much higher than the other two study basins, even though the average basin altitude $(620 \mathrm{~m}$ ) is less than the Mosteiros Basin
( $820 \mathrm{~m}$; table 1). This difference is caused by the orientation and steep topographic relief of the basin and its ability to trap the moisture of ascending air masses associated with both the northeastern trade winds and the equatorial monsoon winds (Haagsma, 1995). Seven-year (1996-2002) average annual precipitation was $509 \mathrm{~mm}$ at the Figueiral Paul station (200-m altitude), $785 \mathrm{~mm}$ at the Passagem station (300-m altitude), and $666 \mathrm{~mm}$ at the Covão station (810-m altitude; fig. 7, table 2; Instituto Nacional de Meteorologia e Geofisica, written commun., 2005). The larger amount of precipitation at Passagem, at an altitude about $500 \mathrm{~m}$ lower than that of Covão, illustrates the spatially erratic nature of precipitation in the 


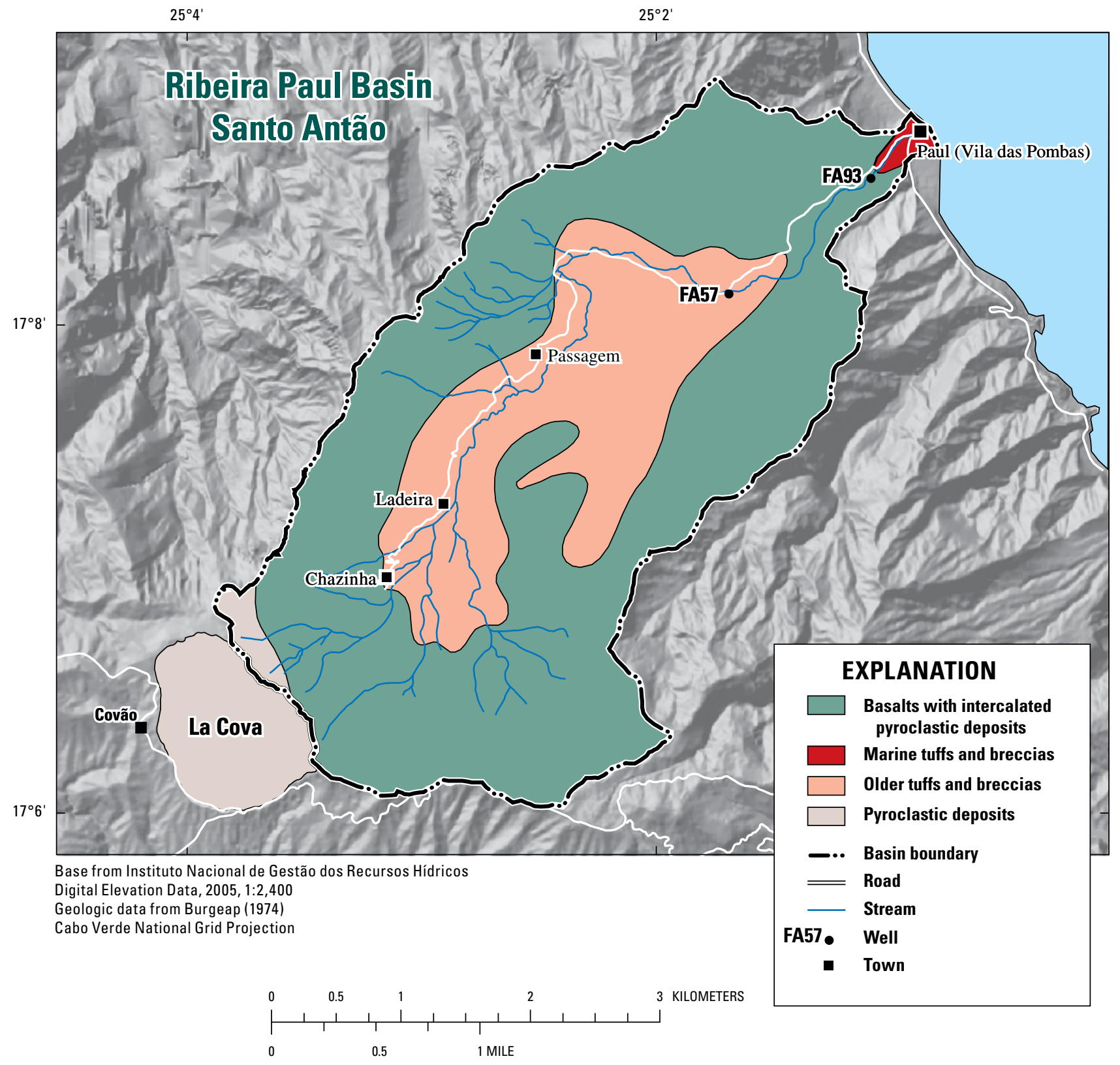

Figure 8. Geology of the Ribeira Paul Basin, Santo Antão, Cape Verde.

basin. These varying microclimates are likely caused by sharp vertical temperature gradients, cloud cover, wind velocity, and topography (Haagsma, 1995). Five-year average precipitation (1945-46, 1948-50) at Vila das Pombas (altitude $20 \mathrm{~m}$ ) was $320 \mathrm{~mm} / \mathrm{yr}$ (Vailleux and Bourguet, 1974).

Ribeira Paul is unique among the three study basins in its abundance of springs and spring-fed streams (about 100). The basins on the northeastern side of Santo Antão, including Ribeira Paul, are the only ones in all of Cape Verde containing perennial streams. Although Ribeira Paul is perennial (except for its lower reaches near well FA93; fig. 7), there are no historical streamflow records. In addition to the larger amount of annual precipitation, there are other possible contributing factors for the abundant ground-water discharge. Its moreincised morphology, compared to that of the other two basins, likely causes the locally perched or regional water table to be intersected by land surface; many of the larger springs and streams discharge from altitudes between 600 to $900 \mathrm{~m}$ at the base of the near-vertical canyon walls. Abundant low-permeability mafic dikes (exposed in outcropping rock throughout the basin), tuffs, and breccias may impede lateral flow and also cause ground-water discharge. Also, subsurface inflow from the adjacent La Cova volcanic caldera likely provides additional recharge to the ground-water system of the Ribeira Paul Basin (fig. 7). La Cova receives substantial precipitation and is a closed basin. None of its rainfall leaves the basin as surface water. Because of its small size and permeable soils, however, there is no reported streamflow within the basin, even after large precipitation events. Rainfall in La Cova is, therefore, either lost to evapotranspiration or becomes subsur- 

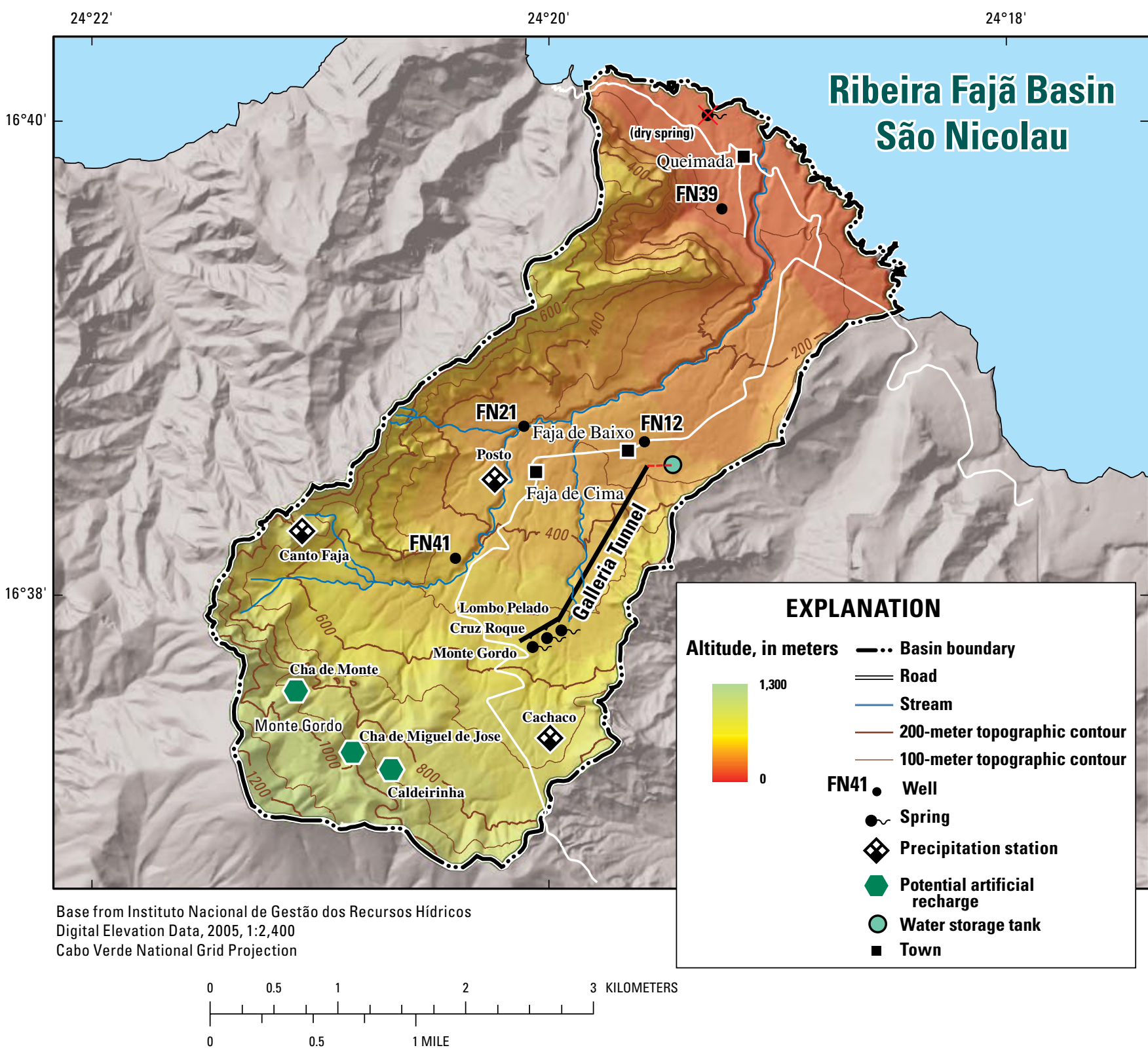

Figure 9. Location of wells, springs, and precipitation stations in the Ribeira Fajã Basin, São Nicolau, Cape Verde.

face recharge, similar to that in the Cha das Caldeiras caldera located adjacent to the Mosteiros Basin.

\section{Ribeira Fajã Basin, São Nicolau}

São Nicolau is located near the center of the Cape Verde island archipelago. The Ribeira Fajã Basin is a deep basin incised in the mountains on the northwestern side of the island (fig. 1). The basin is about the same size as the Ribeira Paul Basin, with an area of $16 \mathrm{~km}^{2}$. The basin's vertical relief of 1,300 m (fig. 9) is also similar to Ribeira Paul Basin, however, Ribeira Fajã Basin is longer than Ribeira Paul Basin, resulting in a smaller average topographic slope of about 23 degrees (table 1).
Like the other two study basins, the geology of the Ribeira Fajã Basin is volcanic. The geologic map (fig. 10) shows exposures of basalt and scoria along much of the main reach of the Ribeira Fajã stream channel (Hidroprojecto Engenharia Gestão, 2000). The side walls and head of the basin have exposed basalts with intercalated pyroclastic deposits, crosscut by near-vertical igneous dikes. The highland area along the southwestern margin of the basin has a thick outcropping layer of pyroclastic deposits, which have weathered to clays at the surface, resulting in a fairly low-permeability surficial soil that likely impedes infiltration of precipitation.

Annual precipitation in the Ribeira Fajã Basin is much less than that in the other two basins. The rain generally occurs between June and December, with the most intense storms during August and September (Langworthy and Finan, 


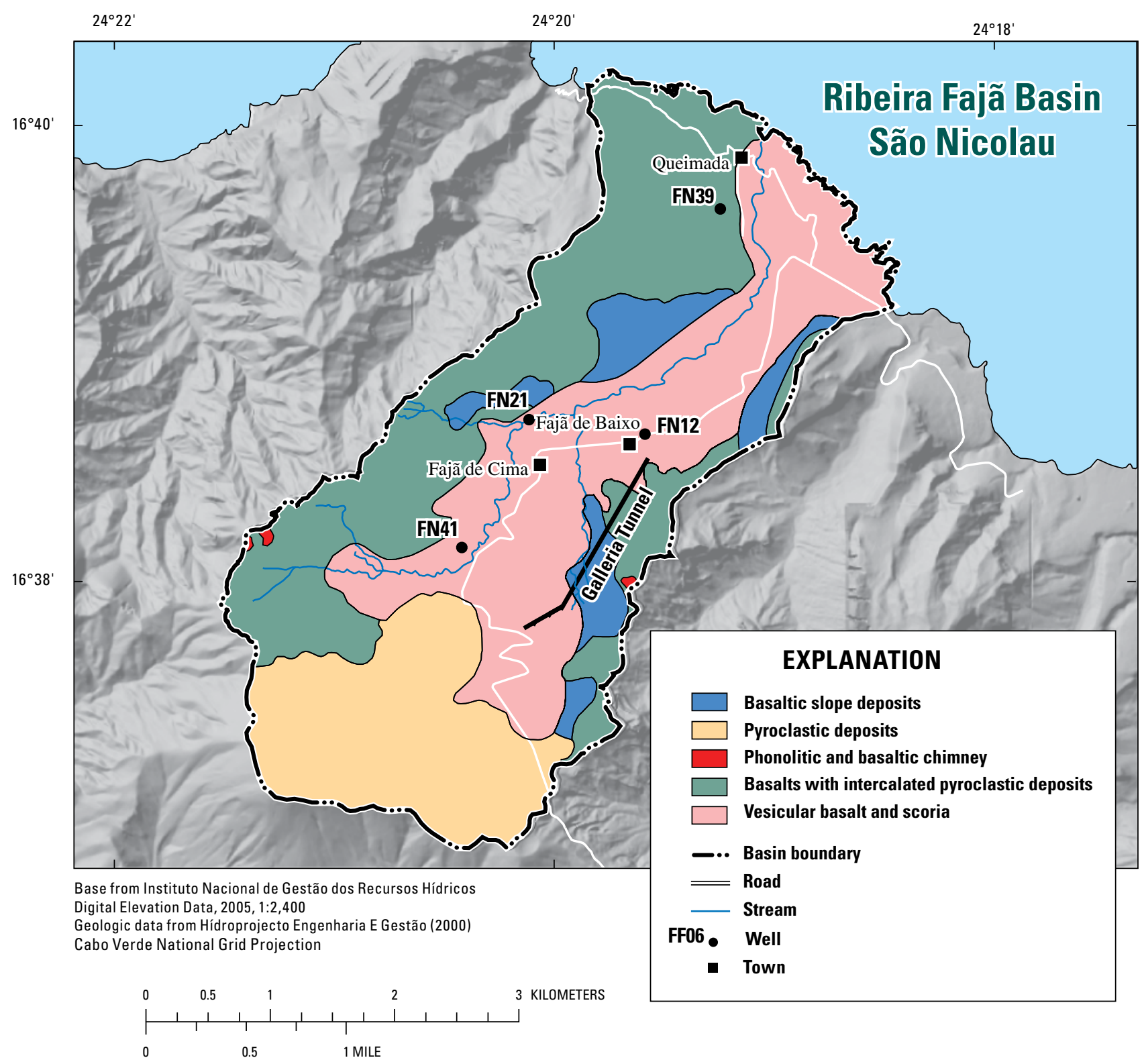

Figure 10. Geology of the Ribeira Fajã Basin, São Nicolau, Cape Verde.

1997). Seven-year (1996-2002) average annual precipitation was $293 \mathrm{~mm}$ at the Posto Fajã station (410-m altitude), 302 $\mathrm{mm}$ at the Canto Fajã station (575-m altitude), and $415 \mathrm{~mm}$ at the Cachaço station (715-m altitude; fig. 9, table 2; Instituto Nacional de Meteorologia e Geofisica, written commun., 2005). In contrast to Ribeira Paul, the Ribeira Fajã Basin follows the expected trend of higher precipitation rates at higher altitudes.

A historical chart of precipitation at the Cachaço station (fig. 11) was constructed from data obtained from the Ministero de Agricultura e Ambiente (written commun., 2005), the Instituto Nacional de Meteorologia e Geofisica (written commun., 2005), Sabino (1986), and Olivry (1981). In order to estimate total precipitation at Cachaço for 2004, the ratio of the average precipitation for the Cachaço and Posto stations for 1978-85, 1995-2002, and 2005 was multiplied by the total 2004 precipitation at Posto. No precipitation data are available within the Ribeira Fajã Basin for 2003. The histogram indicates that the most recent two decades (1984-2005) were wetter than the prior two decades (1961-1983). This illustrates the cyclical nature of precipitation in Cape Verde and is consistent with longer historical records that show periods of several successive extremely dry years (Haagsma, 1995; Langworthy and Finan, 1997). The driest year on record during the past four decades was 1972 , with only $19 \mathrm{~mm}$ of rain; the wettest year was 2002 with $677 \mathrm{~mm}$ of rain (Olivry, 1981). 


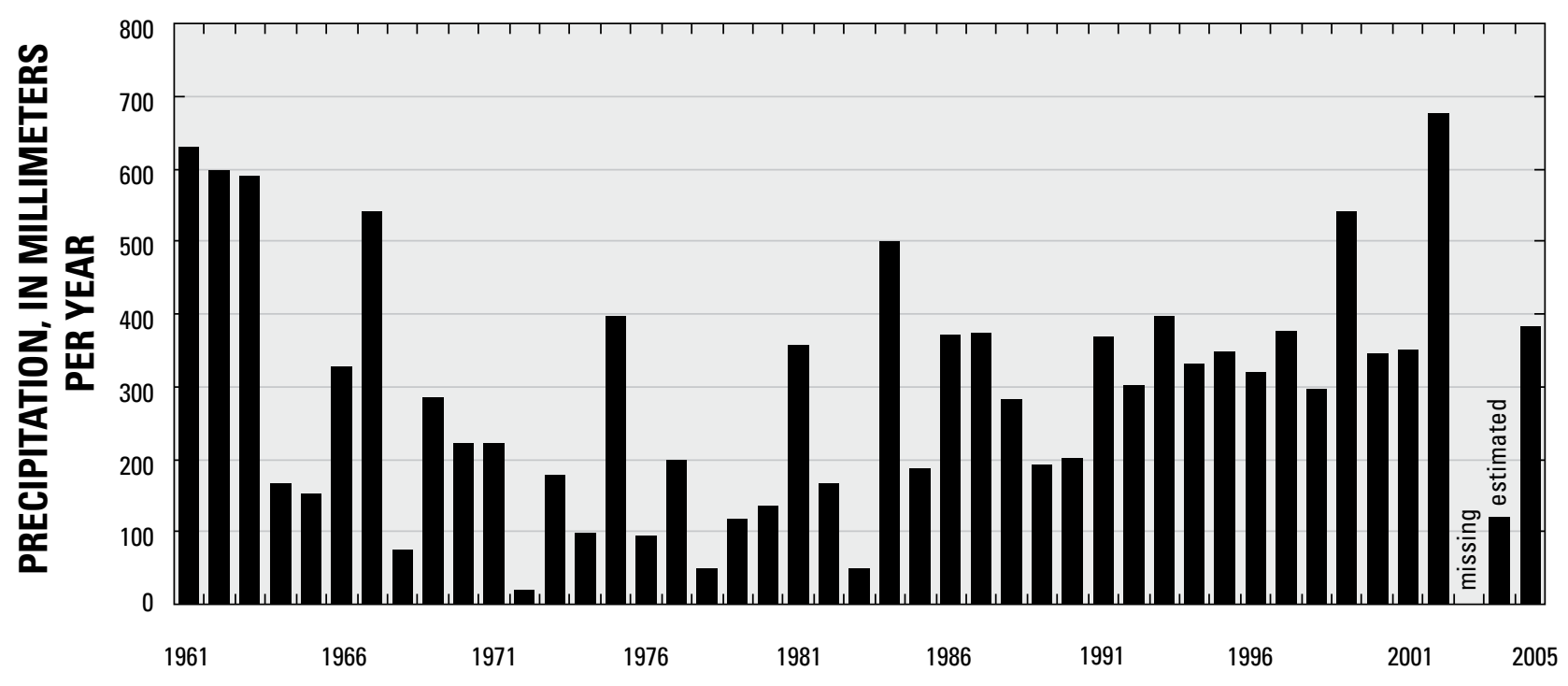

Figure 11. Historical precipitation at Posto Cachaço, Ribeira Fajã Basin, 1961-2005.

\section{Baseline Ground-Water Conditions}

\section{Mosteiros}

\section{Ground-Water Budget}

The measurable sources of ground-water discharge in the Mosteiros Basin are from the Monte Vermelho spring (also referred to as Fajãzinha) and from pumping wells. Submarine discharge, particularly associated with the Monte Vermelho spring, is also known to occur and may be the dominant form of ground-water discharge from the basin. Discharge to the ocean below the spring has been observed during the spring and neap low tides (Jose Manuel Andrade Alves, Agua Brava, oral commun., 2005), but could not be quantified during this study. The two main sources of recharge to the basin are infiltration of precipitation and subsurface inflow from the adjacent Cha das Caldeiras closed basin. A previous report estimated a minimum infiltration rate within Cha das Caldeiras of $9,000 \mathrm{~m}^{3} / \mathrm{d}$ (Kallrén and Schreiber, 1988). Because of the island's conical shape, however, it is likely that much of this infiltration would radiate outward toward other basins besides Mosteiros.

Monte Vermelho is the only large spring within the Mosteiros Basin and one of three large springs on the island of Fogo. It discharges at the base of the columnar basalts of the Principal Eruptive Complex. The spring's location is believed to be controlled by the contact of the basalt with an underlying low-permeability clay layer. This clay layer is thought to dip toward the south beneath the island in a direction opposite

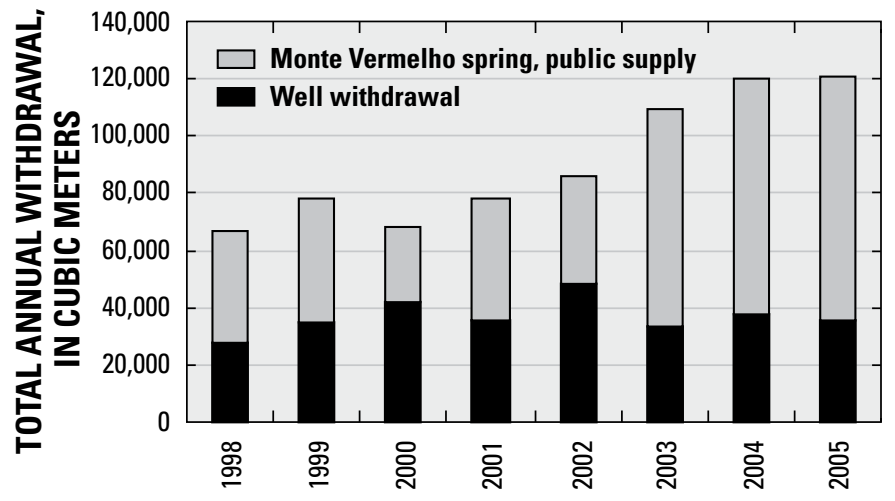

Figure 12. Total annual well withdrawal and the portion of Monte Vermelho spring discharge used for public supply in Mosteiros Basin, 1998-2005.

to the topographic slope, thus acting as a hydraulic barrier and trapping freshwater above it. A discharge of $518 \mathrm{~m}^{3} / \mathrm{d}$ $\left(190,000 \mathrm{~m}^{3} / \mathrm{yr}\right)$ was measured on December 2, 2005 (table 3). This is much higher than a previously measured discharge rate in 1986 of $200 \mathrm{~m}^{3} / \mathrm{d}$ (Kallrén and Schreiber, 1988) and likely represents increased flow associated with recent spring capture enhancements. During 2003-05, about $200 \mathrm{~m}^{3} / \mathrm{d}(80,000$ $\mathrm{m}^{3} / \mathrm{yr}$ ) of the spring discharge was pumped into the municipal water system for public supply (fig. 12; Agua Brava L. da Delegacão dos Mosteiros, written commun., 2006). This is about twice as much as the average reported spring use of about 100 $\mathrm{m}^{3} / \mathrm{d}\left(40,000 \mathrm{~m}^{3} / \mathrm{yr}\right)$ during $1998-2002$. The rest of the water is lost as submarine discharge below the bottom of the catchment tank. 
Table 3. Records of selected springs and streams in the Mosteiros, Ribeira Paul, and Ribeira Fajã Basins, Cape Verde

[Altitude: $\mathrm{m}$, meters; Discharge: $\mathrm{m}^{3} / \mathrm{d}$, cubic meters per day; Specific conductance: $\mu \mathrm{S} / \mathrm{cm}$, microsiemens per centimeter at 25 degrees Celsius; Temperature: ${ }^{\circ} \mathrm{C}$, degrees Celsius; Measurement Agency: INGRH, Instituto Nacional de Gestão dos Recursos Hídricos; MAAP, Ministero do Ambiente, Agricultura e Pescas; SAF, Servicio Autonimo Fajã; USGS, U.S. Geological Survey; _, no data]



${ }^{1}$ Spring and stream sites measured by the INGRH on December 5-6, 2005, do not have specific-conductance measurements because of equipment failure. 
Table 3. Records of selected springs and streams in the Mosteiros, Ribeira Paul, and Ribeira Fajã Basins, Cape Verde-Continued

\begin{tabular}{|c|c|c|c|c|}
\hline Site name & $\begin{array}{c}\text { Discharge } \\
\left(\mathrm{m}^{3} / \mathrm{d}\right)\end{array}$ & $\begin{array}{c}\text { Specific } \\
\text { conductance } \\
(\mu \mathrm{S} / \mathrm{cm})\end{array}$ & $\begin{array}{l}\text { Temper- } \\
\text { ature } \\
\left({ }^{\circ} \mathrm{C}\right)\end{array}$ & $\begin{array}{l}\text { Measurement } \\
\text { agency }\end{array}$ \\
\hline & & Springs & & \\
\hline Tabulera & 95 & 220 & 18.9 & INGRH, USGS \\
\hline NA21 & 100 & 265 & 23.7 & INGRH, USGS \\
\hline Dragueiro \#1 & 19 & 365 & 23.4 & INGRH, USGS \\
\hline Dragueiro \#2 & 34 & 375 & 23.7 & INGRH, USGS \\
\hline \multirow[t]{2}{*}{ Seladinha } & 35 & 1 & 24.1 & INGRH \\
\hline & 23 & 450 & 21.3 & INGRH, USGS \\
\hline Passagem & 950 & 510 & 22.6 & INGRH, USGS \\
\hline \multirow[t]{2}{*}{ Monte Vermelho } & - & 200 & - & INGRH, USGS \\
\hline & 518 & 215 & 22.2 & INGRH, USGS \\
\hline \multirow[t]{2}{*}{ Galleria Fajã (Total) } & 430 & - & - & SAF \\
\hline & 430 & - & - & SAF \\
\hline G. Fajã Monte Gordo Irrigation & 250 & 380 & 21.3 & INGRH, MAAP, USGS \\
\hline G. Fajã Monte Gordo Domestic & 91 & - & - & INGRH, MAAP, USGS \\
\hline G. Fajã Cruz Roque Branch & 56 & 440 & - & INGRH, MAAP, USGS \\
\hline G. Fajã Lombo Pelado Branch & 73 & 550 & - & INGRH, MAAP, USGS \\
\hline \multicolumn{5}{|c|}{ Streams } \\
\hline Ribeirinha & 35 & 1 & 25.0 & INGRH \\
\hline Morcas & 140 & 1 & 18.3 & INGRH \\
\hline Oio de Agua & 63 & 1 & 21.2 & INGRH \\
\hline João Deaninha & 95 & 1 & 26.0 & INGRH \\
\hline Covada Clara & 25 & 1 & 23.3 & INGRH \\
\hline Cabouco & 24 & 1 & 24.0 & INGRH \\
\hline Cringa stream channel & 170 & 440 & 22.4 & INGRH, MAAP, USGS \\
\hline Cringa - Cha de Padre Cima & 230 & 420 & 20.2 & INGRH, MAAP, USGS \\
\hline Zeagrios \# 3 & 86 & 1 & 22.0 & INGRH \\
\hline \multirow{2}{*}{ Zeagrios \# 4} & 320 & 1 & 22.5 & INGRH \\
\hline & 270 & 200 & 19.1 & INGRH, MAAP, USGS \\
\hline Zeagrios \# 5 & 260 & 190 & 19.0 & INGRH, MAAP, USGS \\
\hline Calistrinho & 1,700 & 1 & 23.5 & INGRH \\
\hline Calistrinho A & 300 & 370 & 21.0 & INGRH, MAAP, USGS \\
\hline Calistrinho B & 950 & - & - & INGRH, MAAP, USGS \\
\hline \multirow[t]{2}{*}{ Fidelo Diversion } & 1,200 & $1-$ & 23.2 & INGRH \\
\hline & 780 & 480 & 22.2 & INGRH, USGS \\
\hline Cabelão Diversion & 42 & 590 & 22.0 & MAAP, USGS \\
\hline \multirow[t]{2}{*}{ Ribeira Cabelão } & 19 & $1-$ & 24.2 & INGRH \\
\hline & 420 & 570 & 21.4 & INGRH, USGS \\
\hline Cha João Vaz A & 630 & 410 & 23.2 & INGRH, USGS \\
\hline Cha João Vaz B & 860 & 520 & 23.0 & INGRH, USGS \\
\hline Cha João Vaz C & 240 & 540 & 22.6 & INGRH, USGS \\
\hline Cha João Vaz D & 2,100 & 580 & 22.3 & INGRH, USGS \\
\hline
\end{tabular}


Table 4. Records of selected wells in the Mosteiros, Ribeira Paul, and Ribeira Fajã Basins, Cape Verde [Altitude, Depth of well, and Water level below land surface: $\mathrm{m}$, meters; Pumping rate: $\mathrm{m}^{3} / \mathrm{d}$, cubic meters per day; —, no data]

\begin{tabular}{|c|c|c|c|c|c|c|c|c|c|}
\hline $\begin{array}{l}\text { Well name } \\
\text { FF06 }\end{array}$ & $\begin{array}{c}\text { Basin } \\
\text { Mosteiros }\end{array}$ & \multicolumn{2}{|c|}{$\begin{array}{l}\text { Latitude Longitude } \\
\text { (degree/minute/second) }\end{array}$} & $\begin{array}{c}\begin{array}{c}\text { Altitude } \\
\text { (m) }\end{array} \\
60\end{array}$ & $\begin{array}{c}\text { Year } \\
\text { Drilled }\end{array}$ & $\begin{array}{c}\begin{array}{c}\text { Depth of } \\
\text { well (m) }\end{array} \\
70.6\end{array}$ & $\begin{array}{c}\text { Water level } \\
\text { below land } \\
\text { surface }(\mathbf{m})\end{array}$ & $\begin{array}{c}\text { Date } \\
12 / 02 / 05\end{array}$ & $\begin{array}{c}\text { Pumping } \\
\text { rate } \\
\left(\mathrm{m}^{3} / \mathrm{d}\right)\end{array}$ \\
\hline \multirow[t]{2}{*}{ FF07 } & Mosteiros & 150221 & 0242014 & 20 & & 35.8 & 17.61 & $12 / 02 / 05$ & \\
\hline & & & & & & & 17.57 & $12 / 03 / 05$ & \\
\hline \multirow[t]{2}{*}{ FF21 } & Mosteiros & 150246 & 0242104 & 40 & & 54.3 & - & 08/11/05 & 180 \\
\hline & & & & & & & 39.46 & $12 / 03 / 05$ & \\
\hline FF22 & Mosteiros & 150246 & 0242104 & 40 & & 53.0 & 39.55 & $03 / 11 / 98$ & \\
\hline \multirow[t]{4}{*}{ FF29 } & Mosteiros & 150229 & 0242043 & 60 & 2005 & 61.9 & 51.94 & $06 / 01 / 05$ & \\
\hline & & & & & & & 51.46 & $08 / 12 / 05$ & \\
\hline & & & & & & & 51.45 & $12 / 03 / 05$ & \\
\hline & & & & & & & 51.48 & 03/31/06 & \\
\hline \multirow[t]{3}{*}{ FA57 } & Paul & 170820 & 0250140 & 80 & 1993 & 43.0 & 1.60 & $08 / 17 / 93$ & \\
\hline & & & & & & & 1.29 & $01 / 07 / 94$ & \\
\hline & & & & & & & - & 08/08/05 & 192 \\
\hline FA93 & & & & & & & 16.40 & $06 / 15 / 06$ & \\
\hline FN12 & Fajã & 163839 & 0241935 & 250 & 1978 & 146.0 & 111.10 & $10 / 14 / 78$ & \\
\hline FN21 & Fajã & 163813 & 0242014 & 310 & 1980 & 128.0 & 115.07 & $04 / 10 / 79$ & \\
\hline \multirow[t]{6}{*}{ FN39 } & Fajã & 163950 & 0241914 & 80 & 1980 & 104.3 & 51.54 & $01 / 10 / 80$ & \\
\hline & & & & & & & 52.58 & $10 / 30 / 82$ & \\
\hline & & & & & & & 72.43 & $11 / 02 / 98$ & \\
\hline & & & & & & & 72.81 & $02 / 18 / 02$ & \\
\hline & & & & & & & 73.12 & $12 / 13 / 05$ & \\
\hline & & & & & & & 73.11 & 03/08/06 & \\
\hline \multirow[t]{2}{*}{ FN41 } & Faja & 163758 & 0242042 & 490 & 1980 & 189.2 & 173.40 & $03 / 10 / 80$ & \\
\hline & & 163809 & 0242025 & & & & Dry & 03/08/06 & \\
\hline
\end{tabular}


Currently (2006) two production wells exist in the Mosteiros Basin: FF21 and FF22. Collectively, withdrawals from these wells averaged about $100 \mathrm{~m}^{3} / \mathrm{d}$ between 1998 and 2005 (Agua Brava L. da Delegacão dos Mosteiros, written commun., 2006). Well FF21 had a measured instantaneous pumping rate of $180 \mathrm{~m}^{3} / \mathrm{d}$ on August 11, 2005 (table 4). Well FF22 had a measured instantaneous pumping rate of $470 \mathrm{~m}^{3} / \mathrm{d}$ on December 3, 2005. Combined total annual well withdrawal from the two wells from 1998 to 2005 has varied between about 28,000 and 48,000 $\mathrm{m}^{3}$ (fig. 12). One new well (FF29) was recently completed (2005) with plans to eventually install a submersible pump.

The average annual volume of precipitation falling within the Mosteiros Basin is estimated to be about $2.5 \times 10^{7} \mathrm{~m}^{3}(7$ $\mathrm{x} 10^{4} \mathrm{~m}^{3} / \mathrm{d}$ ). This is based on an average basin altitude of 816 $\mathrm{m}$, an interpolated annual precipitation value of $590 \mathrm{~mm}$, and a basin area of about $42 \mathrm{~km}^{2}$. The interpolated $590 \mathrm{~mm}$ annual precipitation is based on a linear interpolation of the 19962002 average precipitation for the three lower-altitude precipitation stations (75 m, $348 \mathrm{~m}$, and $460 \mathrm{~m}$ ) in the Mosteiros Basin, along with reported precipitation at Monte Velha (850 $\mathrm{m})$ and Cha das Caldeiras $(1,650 \mathrm{~m})$. Combining the Monte Vermelho spring discharge with withdrawals from the two production wells, the total spring and well discharge from the Mosteiros Basin is estimated to be about $620 \mathrm{~m}^{3} / \mathrm{d}$ or 230,000 $\mathrm{m}^{3} / \mathrm{yr}$. Subsurface outflow as submarine discharge is thought to be a large component of the ground-water budget, but could not be quantified during this study. By using the estimated average annual $2.5 \times 10^{7} \mathrm{~m}^{3}$ volume of precipitation falling within the basin, about 1 percent $\left(2.3 \times 10^{5} \mathrm{~m}^{3}\right.$ divided by 2.5 $\mathrm{x} 10^{7} \mathrm{~m}^{3}$ ) of this precipitation is calculated to discharge from the aquifer through wells and springs.

\section{Ground-Water Levels}

Ground-water levels were measured with an electric tape at five wells in the Mosteiros Basin: FF06, FF07, FF21, FF22, and FF29 (table 4). These wells are all located along the coastal plain in the northeastern part of the basin (fig. 5). There are no wells located in the highlands part of the basin to evaluate ground-water levels or ground-water hydraulic gradients. The land-surface altitude of the five wells ranged from about 20 to $60 \mathrm{~m}$ and the depth to water ranged from 18 to $64 \mathrm{~m}$ below land surface. Wells FF06 and FF07 are currently monitoring wells; both were drilled as production wells but subsequently abandoned. Well FF06 had a very low yield during well testing (Agua Brava L. da Delegacão dos Mosteiros, written commun., 2006) and well FF07 had only a thin lens of freshwater overlying brackish water.

A nonvented pressure transducer, barometer, and data logger were installed in well FF07 in December 2005 to continuously record water level and barometric pressure. Barometrically corrected water levels, both corrected and noncorrected for tidal fluctuations, are shown in figure 13. After removing the tidal effects, there is a gradual decline of about $0.2 \mathrm{~m}$ between December 2005 and March 2006. Without additional information, it cannot be determined if this is a seasonal or longer-term decline. A seasonal decline in groundwater level may be caused by either decreased infiltration of precipitation at the end of the rainy season (August-November) or a delayed response to seasonal pumping. The combined monthly pumping of wells FF21 and FF22, located $1.6 \mathrm{~km}$ to the northwest, was $3,600 \mathrm{~m}^{3} /$ month during May-October, 2005, larger than the 4-year (2002-2005) average of about $3,000 \mathrm{~m}^{3} /$ month (Agua Brava L. da Delegacão dos Mosteiros,

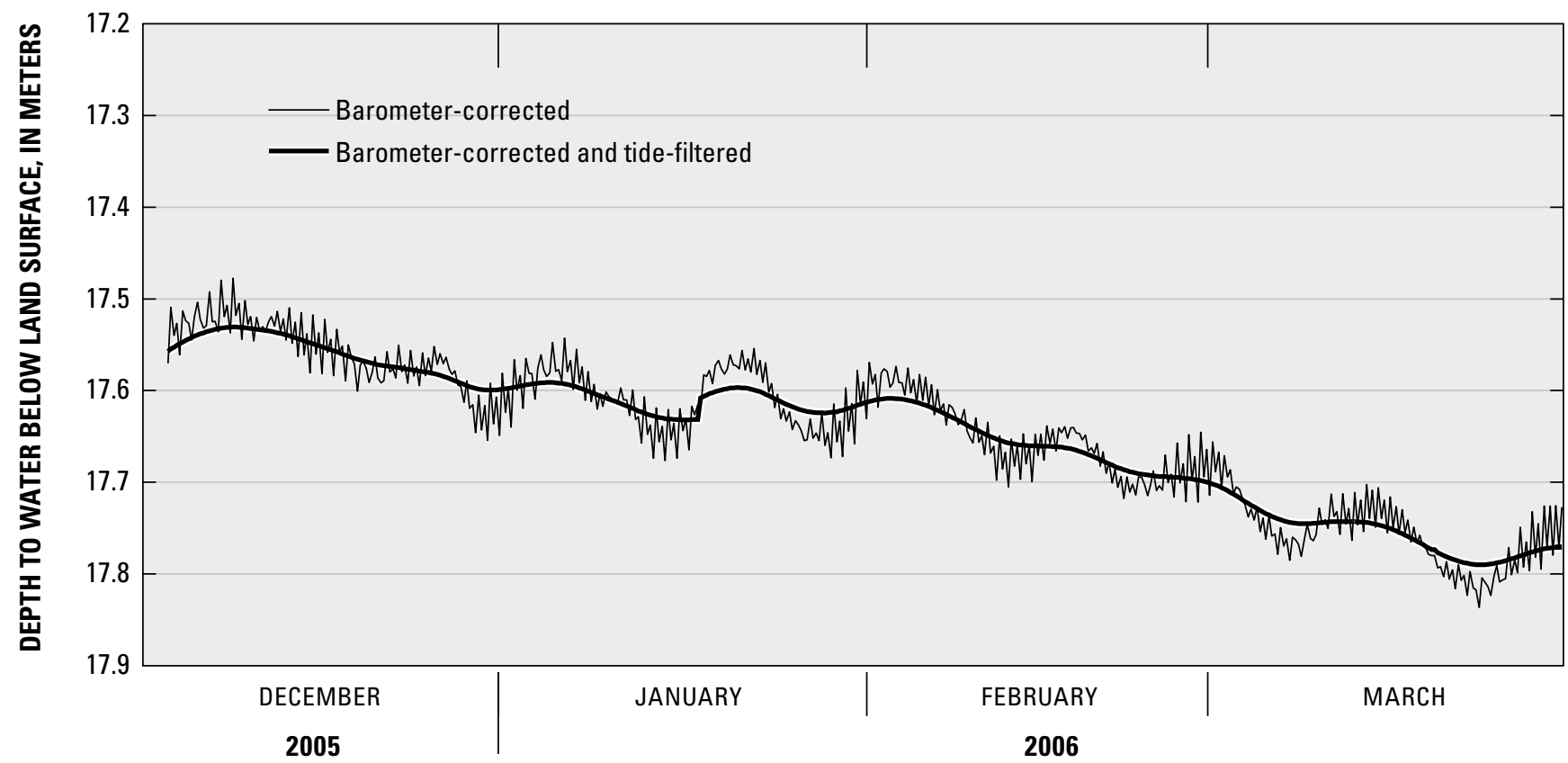

Figure 13. Water level in well FF07, Mosteiros Basin, December 2005 through March 2006. 
written commun., 2006). Because precipitation data were not available beyond 2002, it cannot be determined if the small water-level decline is part of a longer-term climatic trend. Total annual pumping from wells FF21 and FF22 (fig. 12) also does not show any trend of increased pumping as a cause for long-term regional water-level declines.

\section{Water Quality and Environmental Tracers}

The specific-conductance value of ground water in the Mosteiros Basin varies from about 200 to $16,000 \mu \mathrm{S} / \mathrm{cm}$ (table 5; fig. 14). The best-quality (lowest specific-conductance value) water was sampled at the Monte Vermelho spring. The poorest quality (highest specific-conductance value) water was sampled at depth in the FF07 observation well. Because of its proximity to the ocean, a thin lens of fresh ground water in the Mosteiros coastal plain overlies brackish water. Discrete depth sampling with a downhole water-quality meter at FF07 illustrates this (fig. 14). The specific-conductance value of the shallowest $4 \mathrm{~m}$ of water was about $2,200 \mu \mathrm{S} / \mathrm{cm}$, but gradually increased to more than $10,000 \mu \mathrm{S} / \mathrm{cm}$ at a depth of $7 \mathrm{~m}$ below the water table. Similarly, if either of the two production wells in the Mosteiros Basin (FF21 and FF22) pumps more than about $160 \mathrm{~m}^{3} / \mathrm{d}$, they produce brackish water. This influx of brackish water was documented during environmental tracer sampling at FF21 on August 11 and 12, 2005. The specificconductance value of the well water at the beginning of the pumping period was $870 \mu \mathrm{S} / \mathrm{cm}$ and increased to about 1,500 $\mu \mathrm{S} / \mathrm{cm}$ after a 20 -hour pumping period. Therefore, only one well is generally pumped at a time and for a maximum of about 8 hours per day. This is similar to salt-water intrusion problems reported by Kallrén and Schreiber (1988, fig. 4.2) at the Praia Ladrao spring located at a similar altitude $(5 \mathrm{~m})$ on the west coast of Fogo. The specific conductance of water dis-

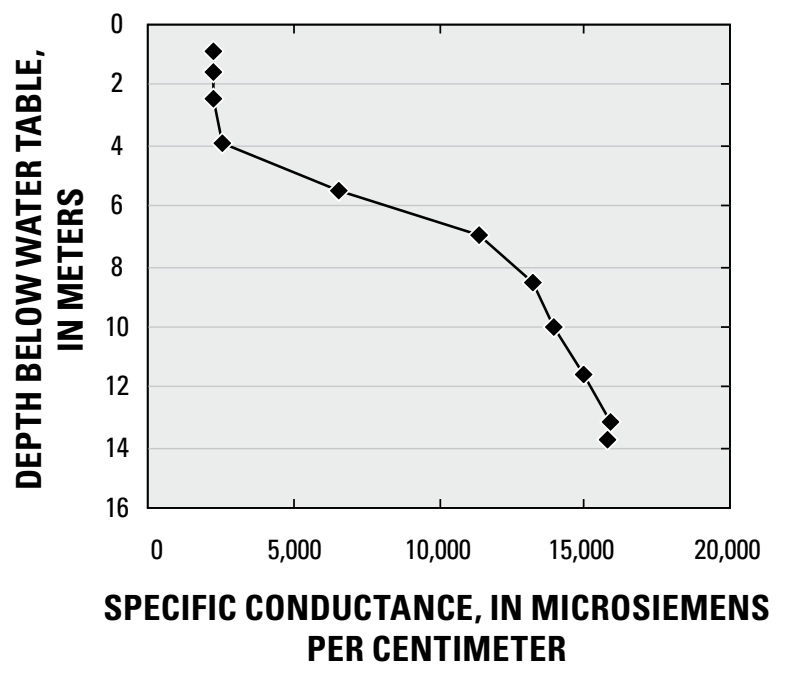

Figure 14. Depth profile of specific-conductance values at well FF07, Mosteiros Basin, December 2005. charging from this spring increased from about 400 to 1,500 $\mu \mathrm{S} / \mathrm{cm}$ during June 1987 and was attributed to pumping.

Ground-water $\mathrm{pH}$ and temperature ranges in the Mosteiros Basin are 6.8 to 7.8 and $20.3^{\circ} \mathrm{C}$ to $23.0^{\circ} \mathrm{C}$, respectively (table 5). These values are similar to those of ground water from the other two study basins and do not indicate upwelling geothermal sources of water. The relatively high dissolvedoxygen concentration of 5.6 to $7.6 \mathrm{mg} / \mathrm{L}$ (61 to 88 percent saturation) indicates oxidized conditions within the aquifer and the lack of substantial bacterial decay of organic matter. Measured total dissolved-gas pressure values were within a very small range (747 to $766 \mathrm{~mm} \mathrm{Hg}$ ) and are nearly identical to barometric pressure values ( 754 to $758 \mathrm{~mm} \mathrm{Hg}$ ), indicating little or no excess gas in the aquifer from air entrapment, degassing of deep geothermal fluids, or anaerobic decay and gas production.

No source precipitation data were collected for stable-isotope analysis within Mosteiros Basin for this study. Stableisotope samples of two agricultural products (wine and juice) from the nearby Cha das Caldeiras were collected, but the analyses were not successful. Stable-isotope concentrations of Fogo precipitation were previously reported at Cha das Caldeiras (-7.0 permil for $\delta^{18} \mathrm{O}$ and -45 permil for $\left.\delta^{2} \mathrm{H}\right)$ and at Achada Fora (-4.0 permil for $\delta^{18} \mathrm{O}$ and -30 permil for $\delta^{2} \mathrm{H}$; Barmen and others, 1990). Except for well FF06, the stableisotope ratios of ground water from the Mosteiros Basin fall within a fairly tight cluster on the meteoric water line (fig. 15 ), with values ranging from -3.4 to -3.8 permil for $\delta^{18} \mathrm{O}$ and from -15 to -21 permil for $\delta^{2} \mathrm{H}$. The water sample from well FF06 is much more depleted $\left(\delta^{18} \mathrm{O}\right.$ of -5.1 and $\delta^{2} \mathrm{H}$ of -28$)$, indicating a higher-altitude precipitation source of recharge to this well. The well is located southeast of the other wells and Monte Vermelho spring, closer to the high-altitude Cha das Caldeiras caldera (fig. 5). The stable-isotope concentrations of the Monte Vermelho spring water do not seem to vary substantially with time: the concentration of $\delta^{18} \mathrm{O}$ and $\delta^{2} \mathrm{H}$ was -3.8 and -21 permil, respectively, on August 12, 2005, and -3.8 and -18 permil, respectively, on December 2, 2005. A previous ground-water isotopic study by Kallrén and Schreiber (1988) reported similar concentrations on October 10, 1987, of -3.9 and -22 permil for $\delta^{2} \mathrm{H}$ and $\delta^{18} \mathrm{O}$, respectively. This indicates a steady, uniform recharge source.

The dissolved-gas concentration of $\mathrm{N}_{2},{ }^{40} \mathrm{Ar},{ }^{84} \mathrm{Kr},{ }^{20} \mathrm{Ne}$, ${ }^{4} \mathrm{He}$, and ${ }^{129} \mathrm{Xe}$ in ground water is listed in table 5. Most of the dissolved gases in ground-water samples from the Mosteiros Basin are of atmospheric origin, as indicated by the close comparison between measured and theoretical atmospherically equilibrated concentrations of the individual gases (K. Solomon, written commun., 2006). Furthermore, the relatively low excess-air concentrations indicate that little air entrapment at the water table or gas generation from within or beneath the aquifer is occurring. Little excess air generally reduces uncertainty in the calculation of recharge temperatures based on dissolved-gas concentrations. Estimated most-probable recharge temperatures are $19^{\circ} \mathrm{C}$ for the Monte Vermelho spring and less than 7 to $19^{\circ} \mathrm{C}$ for wells FF07, 21, 22, and 


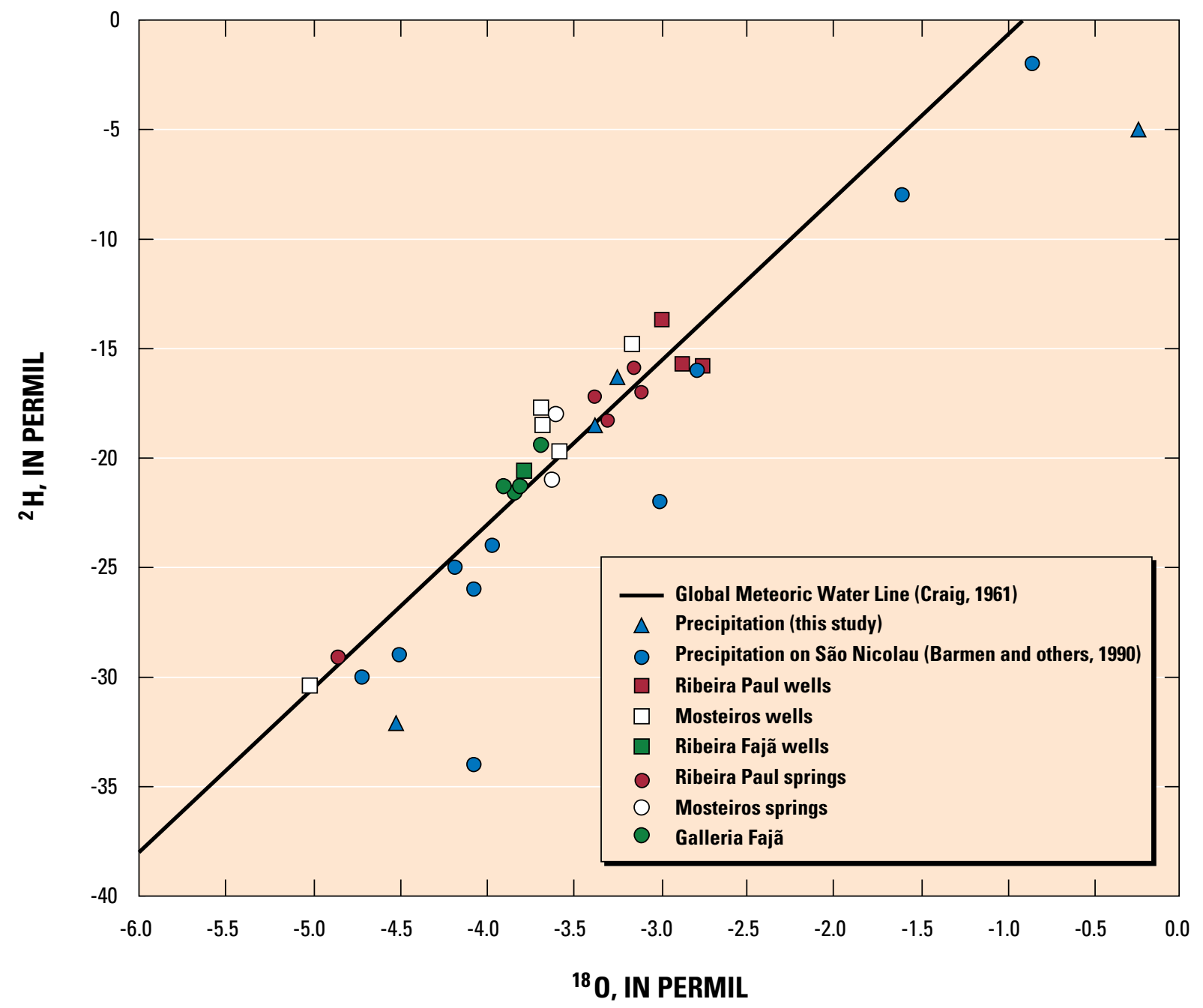

Figure 15. Relation between $\delta^{18} 0$ and $\delta^{2} \mathrm{H}$ values in precipitation and ground water from the Mosteiros, Ribeira Paul, and Ribeira Fajã Basins, Cape Verde.

29. Plotting $\operatorname{Tr}_{\text {min }} / \operatorname{Tr}_{\text {max }}$ ranges for each sample against the temperature lapse curve (fig. 16) indicates a most-probable recharge altitude of $1,000 \mathrm{~m}$ for the Monte Vermelho spring. This is very similar to a previously reported estimate of 900 $\mathrm{m}$ based on the relation between spring altitude and $\delta^{18} \mathrm{O}$ values (Kallrén and Schreiber, 1988). Estimated dissolved-gas recharge altitudes for wells FF07, 21, 22, and 29 range from 1,000 to more than 2,000 $\mathrm{m}$ (table 5). These recharge altitudes are higher than the land-surface altitudes at all of these sites ( 5 to $60 \mathrm{~m}$ ), indicating that recharge to these wells and springs does not occur locally, but rather higher up in the watershed. It also indicates that the water-table altitudes in the recharge zone of Mosteiros basin are much higher than sea level, either because of horizontal flow barriers and compartmentalization (fig. 2) or low permeability of the basalts.

Although no precipitation ${ }^{3} \mathrm{H}$ samples were collected in Mosteiros Basin, two agricultural product samples were analyzed from Cha das Caldeiras: wine from grapes of the 2004 growing season and juice from grapes and pomegranates grown during the 2005 season. These samples had ${ }^{3} \mathrm{H}$ concentrations of 3.0 and $1.0 \mathrm{TU}$, respectively (table 6).
This indicates that precipitation ${ }^{3} \mathrm{H}$ concentrations in Fogo have remained fairly constant since previous sampling in the 1980s. Ground-water ${ }^{3} \mathrm{H}$ concentrations from samples collected in Mosteiros Basin ranged from about 0.2 to 1.2 TU. As discussed in the "Methods" section, values less than 0.3 $\mathrm{TU}$ indicate ground-water recharge that occurred prior to the early 1950s. Water from wells FF06, FF21, and FF29 all had ${ }^{3} \mathrm{H}$ concentrations less than $0.3 \mathrm{TU}$. Water from well FF22 and the Monte Vermelho spring had ${ }^{3} \mathrm{H}$ concentrations between 0.4 and $0.8 \mathrm{TU}$, likely indicating a mixture of pre- and post-1950s recharge (a sample collected from Monte Vermelho spring on April 28, 1980, had a reported ${ }^{3} \mathrm{H}$ concentration of less than 2 TU (Barmen and others, 1990), which would be equivalent to a decay-corrected 2005 concentration of less than $0.5 \mathrm{TU}$ ). Water from well FF07 had a ${ }^{3} \mathrm{H}$ concentration of $1.2 \mathrm{TU}$, indicating either uniform post-1960s recharge or a mixture of pre- and post-1950s recharge.

Elevated dissolved ${ }^{4} \mathrm{He}$ concentrations and ${ }^{3} \mathrm{He}:{ }^{4} \mathrm{He}$ ratios were measured in water from all of the wells sampled in Mosteiros (fig. 17, table 6). This is likely caused by the occur- 


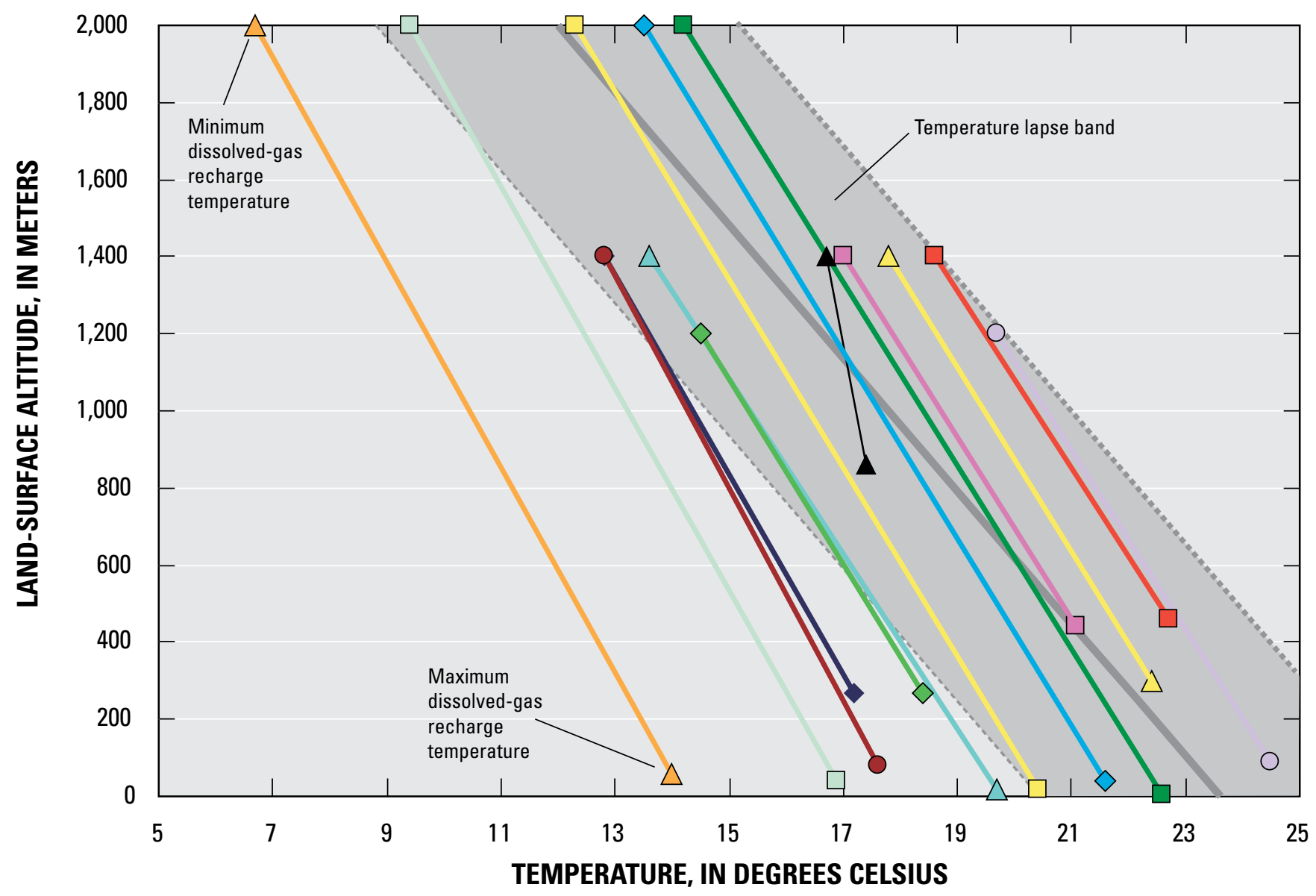

\section{EXPLANATION}
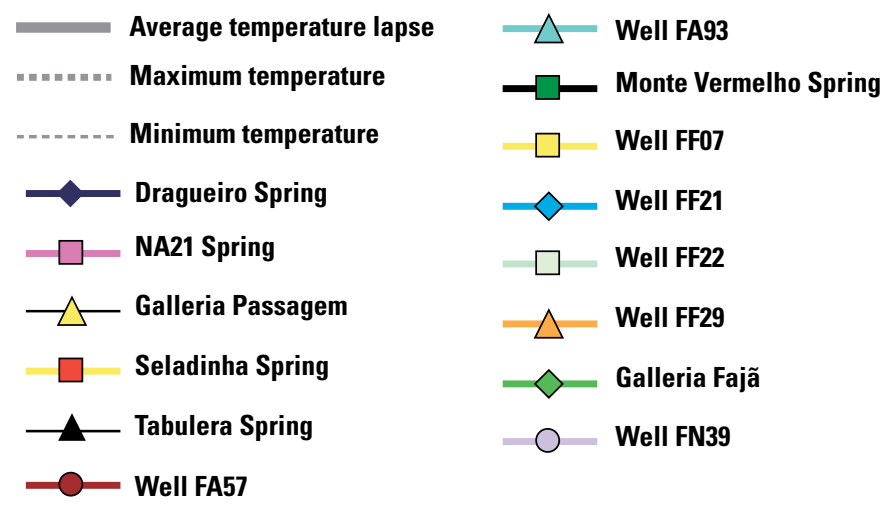

Figure 16. Temperature lapse band (from fig. 3) and the range of possible dissolved-gas ground-water recharge temperatures for sites in Mosteiros, Ribeira Paul, and Ribeira Fajã Basins, Cape Verde. 


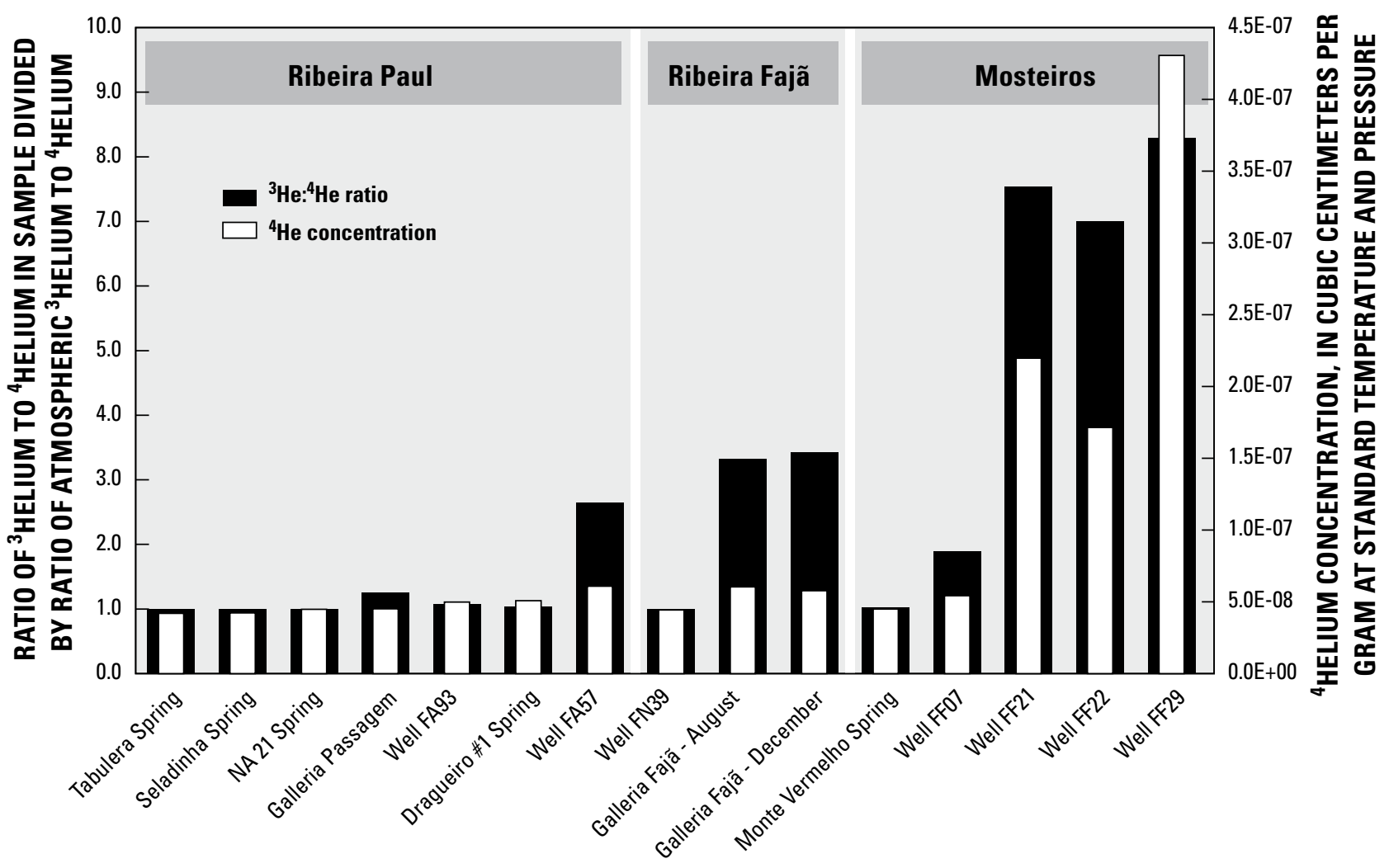

Figure 17. ${ }^{3}$ Helium: ${ }^{4}$ Helium ratios relative to the helium isotopic ratio of air and total ${ }^{4} \mathrm{Helium}$ concentration in ground water from the Mosteiros, Ribeira Paul, and Ribeira Fajã Basins, Cape Verde.

rence of terrigenically derived helium in the aquifer, associated with recent volcanic activity of the island (last eruption in 1995). ${ }^{4} \mathrm{He}$ concentrations from these wells range as much as an order of magnitude higher than typical concentrations measured in atmospherically equilibrated ground water. Similarly, the dissolved ${ }^{3} \mathrm{He}:{ }^{4} \mathrm{He}$ ratios of samples from these wells are as much as eight times $R_{a}$, where $R_{a}$ is the atmospheric ${ }^{3} \mathrm{He}:{ }^{4} \mathrm{He}$ ratio of $1.384 \times 10^{-6}$. This is consistent with earlier studies of mantle-derived helium (Andrews, 1985). Because of its sensitivity to non-atmospheric sources of helium, ${ }^{3} \mathrm{H} /{ }^{3} \mathrm{He}$ age dating of these samples was not possible.

The ${ }^{3} \mathrm{He}$ and ${ }^{4} \mathrm{He}$ concentrations of these and other terrigenically influenced samples, however, are very useful for constraining the ${ }^{3} \mathrm{H} /{ }^{3} \mathrm{He}$ age dating of the Monte Vermelho spring and ground water from other basins not affected by terrigenically derived helium. The relation between the ${ }^{3} \mathrm{He}:{ }^{4} \mathrm{He}$ ratio and the fraction of ${ }^{4} \mathrm{He}$ derived from atmospheric gases in ground-water samples from Mosteiros and the other two basins is shown in figure 18 . The samples not affected by terrigenic helium sources are those having a fraction of ${ }^{4} \mathrm{He}$ derived from the atmosphere equal to about 1.0 and ${ }^{3} \mathrm{He}:{ }^{4} \mathrm{He}$ ratios of about $2 \times 10^{-6}$. The samples that are affected by terrigenic helium plot along a linear trend of increasing ${ }^{3} \mathrm{He}:{ }^{4} \mathrm{He}$ ratio with decreasing fraction of ${ }^{4} \mathrm{He}$ derived from the atmosphere. The extrapolation of this straight line to a zero fraction of atmospherically derived ${ }^{4} \mathrm{He}$ yields a y-intercept $\left({ }^{3} \mathrm{He}:{ }^{4} \mathrm{He}\right.$ ratio) of about $1.3 \times 10^{-5}$, very similar to mantle ratios (Andrews, 1985). This ratio was used as the end-member terrigenic helium value in the age-dating corrections for those ground-water samples not significantly affected by terrigenically derived helium. With this ratio, the Monte Vermelho spring sample collected on December 2, 2005, has an apparent age of 5 to 50 years, indicating that recharge occurred after the 1950s (table 6).

\section{Ribeira Paul}

\section{Ground-Water Discharge}

The measurable sources of ground-water discharge in the Ribeira Paul Basin are to springs, seepage to streams, and well withdrawals. Because of the shallow water table in the basin, ground-water discharge as evapotranspiration also likely occurs. As in Mosteiros Basin, submarine ground-water outflow may be the dominant form of ground-water discharge, but this could not be quantified during this study.

About 100 springs and spring-fed streams are reported in the Ribeira Paul Basin. Measured discharge at five sites where springs discharge directly from the subsurface ranged from 19 to $100 \mathrm{~m}^{3} / \mathrm{d}$ (table 3 ). Measured discharge at 21 stream sites 
Table 5. Selected field measurements, stable isotopes, dissolved-gas concentrations, and estimated recharge temperatures of samples collected from the Mosteiros, Ribeira Paul, and Ribeira Fajã Basins, Cape Verde

[Sample type: precip, precipitation; Altitude: $\mathrm{m}$, meters; Barometric pressure and Total dissolved gas pressure: $\mathrm{mm}$ Hg, millimeters mercury; Dissolved oxygen: $\mathrm{mg} / \mathrm{L}$, milligrams per liter, \%, percent saturation; Specific conductance: $\mu \mathrm{S} / \mathrm{cm}$, microsiemens per centimeter at 25 degrees Celsius; Temperature: ${ }^{\circ} \mathrm{C}$, degrees Celsius; Dissolved gases: $\mathrm{cm}^{3} \mathrm{STP} / \mathrm{g}$, cubic centimeters per gram at standard temperature and pressure; E, exponent; Most probable recharge temperature and altitude: average of most probable range based on intersection of $\operatorname{Tr}_{\min } / \operatorname{Tr}_{\max }$ line with temperature lapse band; —, no data; <, less than; $\geq$, greater than or equal to]

\begin{tabular}{ccccc} 
& & Latitude & Longitude \\
\cline { 3 - 3 } Name & Sample & & & \\
type & Basin & Date & $\begin{array}{c}\text { Altitude } \\
\text { (m) }\end{array}$
\end{tabular}

\begin{tabular}{|c|c|c|c|c|c|c|}
\hline \multirow[t]{3}{*}{ Monte Vermelho } & Spring & Mosteiros & 150254 & 242147 & $10 / 29 / 1987$ & 5 \\
\hline & & & & & $8 / 12 / 2005$ & \\
\hline & & & & & $12 / 2 / 2005$ & \\
\hline${ }^{1} \mathrm{FF} 06$ & Well & Mosteiros & 150133 & 0241908 & $12 / 2 / 2005$ & 60 \\
\hline FF07 & Well & Mosteiros & 150221 & 0242014 & $12 / 2 / 2005$ & 20 \\
\hline FF21 & Well & Mosteiros & 150246 & 0242104 & $8 / 11 / 2005$ & 40 \\
\hline FF22 & Well & Mosteiros & 150246 & 0242104 & $12 / 3 / 2005$ & 40 \\
\hline FF29 & Well & Mosteiros & 150229 & 0242043 & $12 / 3 / 2005$ & 60 \\
\hline Cha das Caldeiras wine & Precip. & Mosteiros & 145830 & 0242150 & 2004 & 1,650 \\
\hline Cha das Caldeiras juice & Precip. & Mosteiros & 145830 & 0242150 & 2005 & 1,650 \\
\hline Dragueiro \#1 & Spring & Paul & 170816 & 0250231 & $12 / 8 / 2005$ & 270 \\
\hline NA21 & Spring & Paul & 170834 & 0250234 & $8 / 6 / 2005$ & 440 \\
\hline Passagem & Spring & Paul & 170756 & 0250232 & $8 / 4 / 2005$ & 300 \\
\hline Seladinha & Spring & Paul & 170711 & 0250249 & $12 / 8 / 2005$ & 460 \\
\hline Tabulera & Spring & Paul & 170654 & 0250328 & $8 / 4 / 2005$ & 840 \\
\hline \multirow[t]{2}{*}{ FA57 } & Well & Paul & 170820 & 0250140 & $8 / 8 / 2005$ & 80 \\
\hline & & & & & $12 / 7 / 2005$ & 80 \\
\hline FA93 & Well & Paul & 170849 & 0250104 & $8 / 5 / 2005$ & 20 \\
\hline \multirow[t]{2}{*}{ Ribeira Grande } & Precip. & Paul & 171049 & 0250356 & $11 / 22 / 2005$ & 18 \\
\hline & & & & & $11 / 24 / 2005$ & \\
\hline Vila das Pombas & Precip. & Paul & 170851 & 0250048 & $11 / 23 / 2005$ & 10 \\
\hline \multirow[t]{2}{*}{ G. Fajã - Monte Gordo } & Spring & Fajã & 163845 & 0241927 & $8 / 18 / 2005$ & 270 \\
\hline & & & & & $12 / 14 / 2005$ & \\
\hline G. Fajã - Cruz Roque & Spring & Fajã & 163845 & 0241927 & $12 / 15 / 2005$ & 267 \\
\hline G. Faja - Lombo Pelado & Spring & Fajã & 163845 & 0241927 & $12 / 15 / 2005$ & 265 \\
\hline FN39 & Well & Fajã & 163950 & 0241914 & $12 / 13 / 2005$ & 90 \\
\hline Posto Fajã & Precip. & Fajã & 163829 & 0242012 & 9/16/2005 & 410 \\
\hline
\end{tabular}


Table 5. Selected field measurements, stable isotopes, dissolved-gas concentrations, and estimated recharge temperatures of samples collected from the Mosteiros, Ribeira Paul, and Ribeira Fajã Basins, Cape Verde-Continued

\begin{tabular}{|c|c|c|c|c|c|c|c|c|}
\hline \multicolumn{7}{|c|}{ Field measurements } & \multicolumn{2}{|c|}{ Stable isotopes } \\
\hline $\begin{array}{c}\text { Baro- } \\
\text { metric } \\
\text { pressure } \\
(\mathrm{mm} \mathrm{Hg})\end{array}$ & $\begin{array}{c}\text { Total } \\
\text { dissolved } \\
\text { gas } \\
\text { pressure } \\
\text { (mm Hg) }\end{array}$ & $\begin{array}{c}\text { Total } \\
\text { dissolved } \\
\text { gas } \\
\text { pressure } \\
\text { (atm) }\end{array}$ & $\begin{array}{c}\text { Dissolved } \\
\text { oxygen } \\
\text { (mg/L and } \\
\text { (percent } \\
\text { saturation)) }\end{array}$ & $\begin{array}{c}\text { Specific } \\
\text { conduct- } \\
\text { ance } \\
(\mu \mathrm{S} / \mathrm{cm})\end{array}$ & $\begin{array}{c}\mathrm{pH} \\
\text { (standard } \\
\text { units) }\end{array}$ & $\begin{array}{l}\text { Temp- } \\
\text { erature } \\
\left({ }^{\circ} \mathrm{C}\right)\end{array}$ & $\begin{array}{c}\delta^{2} \mathbf{H} \\
\text { (permil) }\end{array}$ & $\begin{array}{c}\delta^{180} 0 \\
\text { (permil) }\end{array}$ \\
\hline- & - & - & - & - & - & - & -22.3 & -3.94 \\
\hline- & - & - & - & 200 & 7.2 & - & -21.0 & -3.78 \\
\hline 758 & 763 & 1.00 & $7.6(88 \%)$ & 210 & 7.3 & 22.2 & -18.0 & -3.76 \\
\hline 755 & 758 & 1.00 & $5.6(61 \%)$ & 2,280 & 6.8 & 20.3 & -27.7 & -5.08 \\
\hline 758 & 747 & .98 & $7.5(87 \%)$ & 2,240 & 7.8 & 22.8 & -14.8 & -3.35 \\
\hline 757 & 766 & 1.01 & $7.1(82 \%)$ & 870 & 7.0 & 23.0 & -19.7 & -3.74 \\
\hline 758 & 756 & .99 & $7.1(82 \%)$ & 700 & 7.4 & 22.4 & -18.5 & -3.83 \\
\hline 754 & 758 & 1.00 & $6.4(74 \%)$ & 1,440 & 7.4 & 22.7 & -17.7 & -3.84 \\
\hline- & - & - & - & - & - & - & - & - \\
\hline - & - & - & - & - & - & - & - & - \\
\hline 738 & 721 & .95 & $3.0(38 \%)$ & 375 & 7.1 & 23.4 & -15.9 & -3.34 \\
\hline 743 & 729 & .96 & $4.6(54 \%)$ & 265 & 7.0 & 23.7 & -17.0 & -3.30 \\
\hline 741 & 730 & .96 & $5.7(73 \%)$ & 510 & 7.2 & 22.6 & -18.3 & -3.48 \\
\hline 720 & 712 & .94 & $6.5(78 \%)$ & 450 & 7.8 & 21.3 & -17.2 & -3.55 \\
\hline 694 & 689 & .91 & $7.5(88 \%)$ & 220 & 7.6 & 18.9 & -29.1 & -4.93 \\
\hline - & - & - & - & 580 & 7.1 & - & -15.7 & -3.08 \\
\hline 753 & 777 & 1.02 & $5.0(61 \%)$ & 580 & 7.4 & 24.0 & -13.7 & -3.19 \\
\hline 762 & 745 & .98 & $5.3(60 \%)$ & 710 & 7.2 & 23.0 & -15.8 & -2.97 \\
\hline - & - & - & - & - & - & - & -16.3 & -3.43 \\
\hline - & - & - & - & - & - & - & -18.5 & -3.55 \\
\hline - & - & - & - & - & - & - & -32.1 & -4.62 \\
\hline 738 & 737 & .97 & $7.2(84 \%)$ & 380 & 7.8 & 21.3 & -21.6 & -3.98 \\
\hline 737 & 744 & .98 & $7.9(89 \%)$ & 380 & 8.3 & 21.3 & -21.3 & -4.04 \\
\hline - & - & - & - & 440 & - & - & -21.3 & -3.95 \\
\hline - & - & - & - & 550 & - & - & -19.4 & -3.84 \\
\hline 755 & 760 & 1.00 & $5.7(68 \%)$ & 500 & 7.6 & 23.9 & -20.6 & -3.93 \\
\hline- & - & - & - & - & - & - & -5.0 & -.63 \\
\hline
\end{tabular}


Table 5. Selected field measurements, stable isotopes, dissolved-gas concentrations, and estimated recharge temperatures of samples collected from the Mosteiros, Ribeira Paul, and Ribeira Fajã Basins, Cape Verde—Continued

\begin{tabular}{|c|c|c|c|c|c|c|c|c|c|}
\hline \multirow[b]{2}{*}{ Name } & \multicolumn{6}{|c|}{ Dissolved gases } & \multirow[b]{2}{*}{$\begin{array}{l}\text { Excess air } \\
\left(\mathrm{cm}^{3} \mathrm{STP} / \mathrm{g}\right)\end{array}$} & \multirow{2}{*}{$\begin{array}{c}\text { Most } \\
\text { probable } \\
\text { recharge } \\
\text { temper- } \\
\text { ature } \\
\left({ }^{\circ} \mathrm{C}\right)\end{array}$} & \multirow{2}{*}{$\begin{array}{c}\text { Most } \\
\text { probable } \\
\text { recharge } \\
\text { altitude } \\
\text { (meters) }\end{array}$} \\
\hline & $\begin{array}{c}\mathrm{N}_{2} \\
\left(\mathrm{~cm}^{3} \mathrm{STP} / \mathrm{g}\right)\end{array}$ & $\begin{array}{c}{ }^{40} \mathrm{Ar} \\
\left(\mathrm{cm}^{3} \mathrm{STP} / \mathrm{g}\right)\end{array}$ & $\begin{array}{c}{ }^{84} \mathrm{Kr} \\
\left(\mathrm{cm}^{3} \mathrm{STP} / \mathrm{g}\right)\end{array}$ & $\begin{array}{c}{ }^{20} \mathrm{Ne} \\
\left(\mathrm{cm}^{3} \mathrm{STP} / \mathrm{g}\right)\end{array}$ & $\begin{array}{c}{ }^{4} \mathrm{He} \\
\left(\mathrm{cm}^{3} \mathrm{STP} / \mathrm{g}\right)\end{array}$ & $\begin{array}{c}{ }^{129} \mathrm{Xe} \\
\left(\mathrm{cm}^{3} \mathrm{STP} / \mathrm{g}\right)\end{array}$ & & & \\
\hline \multirow[t]{3}{*}{ Monte Vermelho } & - & - & - & - & - & - & - & - & - \\
\hline & - & - & - & - & - & - & - & - & - \\
\hline & $1.11 \mathrm{E}-2$ & $2.98 \mathrm{E}-4$ & $3.77 \mathrm{E}-8$ & $1.71 \mathrm{E}-7$ & $4.49 \mathrm{E}-8$ & $2.37 \mathrm{E}-9$ & .000 & 19 & 1,000 \\
\hline${ }^{1} \mathrm{FF} 06$ & - & - & - & - & - & - & - & - & - \\
\hline FF07 & $1.25 \mathrm{E}-2$ & $3.24 \mathrm{E}-4$ & $3.98 \mathrm{E}-8$ & $1.82 \mathrm{E}-7$ & $5.43 \mathrm{E}-8$ & $2.48 \mathrm{E}-9$ & .001 & 19 & 1,000 \\
\hline FF21 & $1.17 \mathrm{E}-2$ & $3.08 \mathrm{E}-4$ & $3.83 \mathrm{E}-8$ & $1.69 \mathrm{E}-7$ & $2.20 \mathrm{E}-7$ & $2.33 \mathrm{E}-9$ & .000 & 19 & 1,000 \\
\hline FF22 & $1.28 \mathrm{E}-2$ & $3.27 \mathrm{E}-4$ & $4.37 \mathrm{E}-8$ & $1.66 \mathrm{E}-7$ & $1.71 \mathrm{E}-7$ & $2.67 \mathrm{E}-9$ & .000 & 13 & 1,800 \\
\hline FF29 & $1.41 \mathrm{E}-2$ & $3.72 \mathrm{E}-4$ & $4.66 \mathrm{E}-8$ & $1.93 \mathrm{E}-7$ & $4.31 \mathrm{E}-7$ & $2.93 \mathrm{E}-9$ & .001 & $<7$ & $\geq 2,000$ \\
\hline Cha das Caldeiras wine & - & - & - & - & - & - & - & - & - \\
\hline Cha das Caldeiras juice & - & - & - & - & - & - & - & - & - \\
\hline Dragueiro \#1 & $1.32 \mathrm{E}-2$ & $3.42 \mathrm{E}-4$ & $4.15 \mathrm{E}-8$ & $1.91 \mathrm{E}-7$ & $5.08 \mathrm{E}-8$ & $2.65 \mathrm{E}-9$ & .002 & 13 & 1,300 \\
\hline NA21 & $1.14 \mathrm{E}-2$ & $2.98 \mathrm{E}-4$ & $3.79 \mathrm{E}-8$ & $1.64 \mathrm{E}-7$ & $4.47 \mathrm{E}-8$ & $2.19 \mathrm{E}-9$ & .000 & 19 & 900 \\
\hline Passagem & $1.16 \mathrm{E}-2$ & $2.96 \mathrm{E}-4$ & $3.59 \mathrm{E}-8$ & $1.66 \mathrm{E}-7$ & $4.51 \mathrm{E}-8$ & $2.21 \mathrm{E}-9$ & .000 & 20 & 900 \\
\hline Seladinha & $1.10 \mathrm{E}-2$ & $2.86 \mathrm{E}-4$ & $3.52 \mathrm{E}-8$ & $1.58 \mathrm{E}-7$ & $4.23 \mathrm{E}-8$ & $2.13 \mathrm{E}-9$ & .000 & 21 & 900 \\
\hline Tabulera & $1.16 \mathrm{E}-2$ & $2.99 \mathrm{E}-4$ & $3.86 \mathrm{E}-8$ & $1.57 \mathrm{E}-7$ & $4.19 \mathrm{E}-8$ & $2.42 \mathrm{E}-9$ & .000 & 17 & 1,100 \\
\hline \multirow[t]{2}{*}{ FA57 } & - & - & - & - & - & - & - & - & - \\
\hline & $1.45 \mathrm{E}-2$ & $3.24 \mathrm{E}-4$ & $4.34 \mathrm{E}-8$ & $1.80 \mathrm{E}-7$ & $6.09 \mathrm{E}-8$ & $2.57 \mathrm{E}-9$ & .001 & 13 & 1,300 \\
\hline FA93 & $1.33 \mathrm{E}-2$ & $3.30 \mathrm{E}-4$ & $3.91 \mathrm{E}-8$ & $1.82 \mathrm{E}-7$ & $4.98 \mathrm{E}-8$ & $2.37 \mathrm{E}-9$ & .001 & 16 & 900 \\
\hline \multirow[t]{2}{*}{ Ribeira Grande } & - & - & - & - & - & - & - & - & 一 \\
\hline & - & - & - & - & - & - & - & - & - \\
\hline Vila das Pombas & - & - & - & - & - & - & - & - & 一 \\
\hline \multirow[t]{2}{*}{ G. Fajã - Monte Gordo } & $1.21 \mathrm{E}-2$ & $3.20 \mathrm{E}-4$ & $3.94 \mathrm{E}-8$ & $1.74 \mathrm{E}-7$ & $6.04 \mathrm{E}-8$ & $2.63 \mathrm{E}-9$ & .001 & 16 & 900 \\
\hline & $1.23 \mathrm{E}-2$ & $3.05 \mathrm{E}-4$ & $3.75 \mathrm{E}-8$ & $1.54 \mathrm{E}-7$ & $5.77 \mathrm{E}-8$ & $2.51 \mathrm{E}-9$ & .000 & ${ }^{2} 19$ & - \\
\hline G. Fajã - Cruz Roque & - & - & - & - & - & - & - & - & - \\
\hline G. Faja - Lombo Pelado & - & - & - & - & - & - & - & - & - \\
\hline FN39 & $1.08 \mathrm{E}-2$ & $2.92 \mathrm{E}-4$ & $3.68 \mathrm{E}-8$ & $1.69 \mathrm{E}-7$ & $4.44 \mathrm{E}-8$ & $2.08 \mathrm{E}-9$ & .001 & 22 & 700 \\
\hline Posto Fajã & - & - & - & - & - & - & - & - & - \\
\hline
\end{tabular}

${ }^{1}$ The diffusion sampler for this site was improperly sealed; no dissolved gases were analyzed.

${ }^{2}$ The chi squared error is too high, likely caused by natural or sample-collection gas stripping (causing artificially high recharge temperatures). 


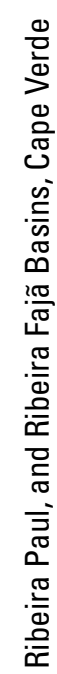

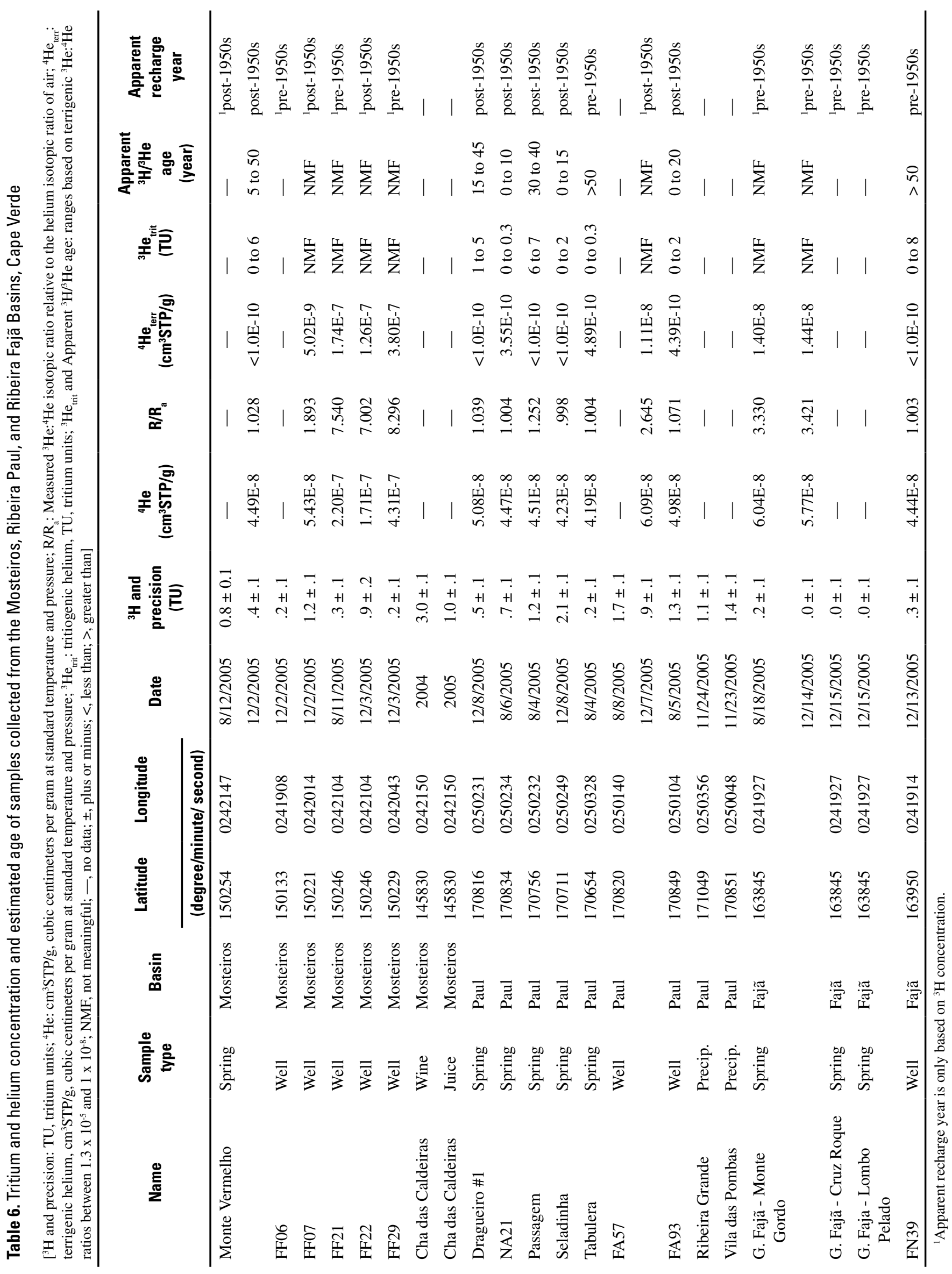




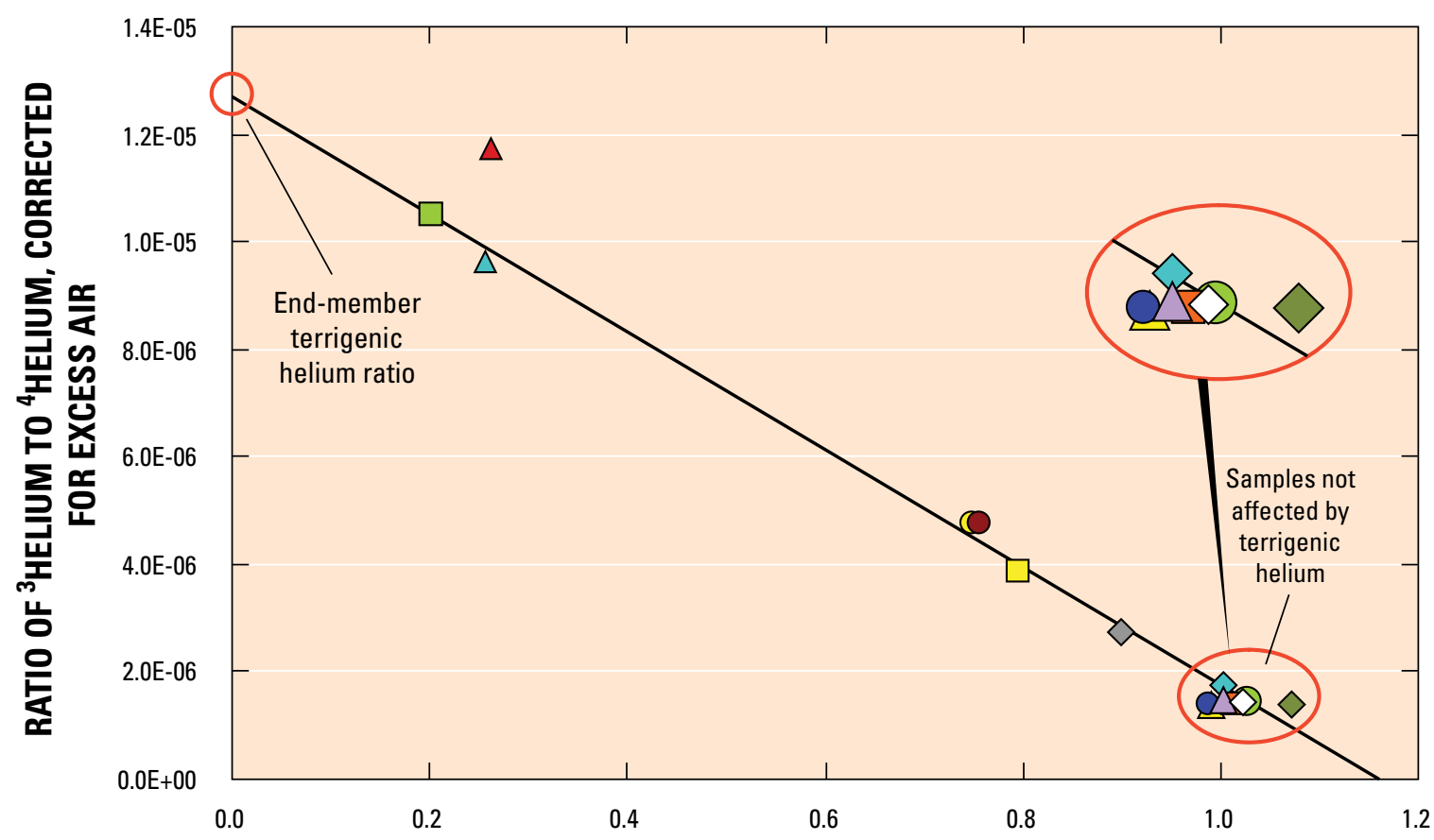

FRACTION OF ${ }^{4}$ HELIUM DERIVED FROM ATMOSPHERE, CORRECTED FOR EXCESS AIR

\section{EXPLANATION}

$\begin{array}{ll} & \text { Linear fit } \\ \diamond & \text { Drageiro Spring } \\ \triangle & \text { NA21 Spring } \\ \diamond & \text { Galleria Passagem } \\ \square & \text { Seladinha Spring } \\ \bigcirc & \text { Tabulera Spring } \\ \square & \text { Well FA57 } \\ \triangle & \text { Well FA93 }\end{array}$

$\begin{array}{ll}\bigcirc & \text { Monte Vermelho Spring } \\ \diamond & \text { Well FF07 } \\ \square & \text { Well FF21 } \\ \triangle & \text { Well FF22 } \\ \triangle & \text { Well FF29 } \\ \bigcirc & \text { Galleria Fajã - August } \\ \bigcirc & \text { Galleria Fajã - December } \\ \diamond & \text { Well FN39 }\end{array}$

Figure 18. Relation between the ${ }^{3}$ Helium: ${ }^{4}$ Helium ratio and fraction of ${ }^{4} \mathrm{Helium}$ derived from atmospheric gases in ground water from the Mosteiros, Ribeira Paul, and Ribeira Fajã Basins, Cape Verde.

ranged from 19 to about 2,100 $\mathrm{m}^{3} / \mathrm{d}$. These streams include both high-altitude spring-fed streams and lower-altitude coalescing flow from tributary streams and irrigation canals. The 27 spring- and stream-discharge measurements made during this study provide a baseline for future evaluation of ground-water resources in the Ribeira Paul Basin.

A total spring and spring-fed stream discharge of about $4,000 \mathrm{~m}^{3} / \mathrm{d}$ is estimated for the Ribeira Paul Basin. This quantity is based primarily on a cross section established at the Ribeira Cha João Vaz site along Ribeira Paul stream channel (fig. 7). The combined discharge of about $3,800 \mathrm{~m}^{3} / \mathrm{d}$ from the streambed and three diversions at this site (Ribeira Cha João Vaz A through D, table 3) represent all of the discharge above this point in the basin except for (1) the two black plastic pipes parallel to the stream carrying public-supply water, and (2) upgradient consumptive use of spring discharge by natural flora and irrigated agriculture. The public-supply pipes are small diameter and divert a relatively small proportion of the upper basin flow. The amount of consumptive use by natural flora and irrigated agriculture in the upper basin was not evaluated during this study. In addition to the Ribeira Cha João Vaz cross section, a total flow of about $200 \mathrm{~m}^{3} / \mathrm{d}$ from mid-basin springs (NA21, Dragueiro \#1, Dragueiro \#2) and spring-fed streams (Ribeirinha and Ribeira Cabouço) along the northwest wall of the valley is included in the total discharge estimate. Because the discharge at Ribeira Cha João Vaz was measured in stream channels soon after the end of the rainy season, it may include some surface-water flow and could overestimate the yearly average ground-water discharge above this point. In contrast, because the measured discharge at Ribeira Cha João Vaz does not include evapotranspiration or diverted publicsupply water, it may be an underestimate of actual groundwater discharge. Although there is much uncertainty in the $4,000 \mathrm{~m}^{3} / \mathrm{d}$ spring-discharge estimate, it is generally consistent with the previous estimate of $7,500 \mathrm{~m}^{3} / \mathrm{d}$ of combined ground- 
water infiltration made by Vailleux and Bourguet (1974) for both Ribeira Paul Basin and the adjacent Ribeira Mesa Basin.

Well FA57 is the only production well in the Ribeira Paul Basin. An instantaneous pumping rate of $190 \mathrm{~m}^{3} / \mathrm{d}$ was measured on August 8, 2005. It pumps about 4 hours per day to provide culinary water for the town of Vila das Pombas (Joãs Jose Andrade Sausa, Santo Antão Agua e Sanitación, oral commun., 2005), resulting in an average daily discharge of about $30 \mathrm{~m}^{3}$. Well withdrawal, therefore, is a relatively insignificant part of the total ground-water discharge from the Ribeira Paul Basin.

The average annual volume of precipitation falling within the Ribeira Paul Basin is estimated to be about $1.0 \times 10^{7} \mathrm{~m}^{3}$. This is based on an estimated average annual precipitation of $650 \mathrm{~mm}$ and a basin area of $15 \mathrm{~km}^{2}$. Unlike the other two basins, there is no clear trend of increasing precipitation with increasing altitude in Ribeira Paul. Therefore, rather than using a linear interpolation and average basin altitude, the estimated $650 \mathrm{~mm}$ annual precipitation is based on the average of the 1996-2002 average precipitation for the three precipitation stations. Combining estimated total spring discharge with withdrawals from the one production well, the total spring and well discharge from the Paul Basin is estimated to be about $4,000 \mathrm{~m}^{3} / \mathrm{d}$ or $1.5 \times 10^{6} \mathrm{~m}^{3} / \mathrm{yr}$. Subsurface outflow as submarine discharge is thought to be a large component of the ground-water budget but could not be quantified during this study. By using the estimated average annual $1.0 \times 10^{7} \mathrm{~m}^{3}$ volume of precipitation falling within the basin, about 15 percent of this precipitation is calculated to discharge from the aquifer through wells and springs.

\section{Ground-Water Levels}

During this study, ground-water levels in the Ribeira Paul Basin were measured only at well FA93. This well is currently the only open borehole suitable for water-level observations. It was drilled in 2004 and is located at an altitude of about $20 \mathrm{~m}$ along the lower end of the Ribeira Paul stream channel. Although most of Ribeira Paul is perennial, this lowest reach is ephemeral and generally does not flow during the dry season. The well was drilled to a depth of 21 meters and is finished in streambed alluvium. Electric-tape and barometrically corrected transducer water-level measurements (fig. 19) indicate that the water level has varied between 14.6 and $16.4 \mathrm{~m}$ below land surface. Because of the relatively large water-level changes at this well, it was not necessary to correct for tidal effects. The highest level of $14.6 \mathrm{~m}$ was recorded on January 29,2006 , shortly after the rainy season and when the nearby stream had flowing water. A vented transducer and data logger were installed in well FA93 in December 2005 to continuously record ground-water levels. In combination with electric-tape measurements in August 2005 and June 2006, the hydrograph shows a rise of about $0.8 \mathrm{~m}$ between August and January, followed by a decline of about $1.8 \mathrm{~m}$ between January and June. This is likely associated with the nearby stream, which only flows for a short time during and after the rainy season. In 2005, the major precipitation events occurred in November, with flow remaining in the stream channel through January. Because of the strong effects of the nearby stream, additional water-level measurements are needed to confirm that the changes are seasonal and not longer-term trends. Because this

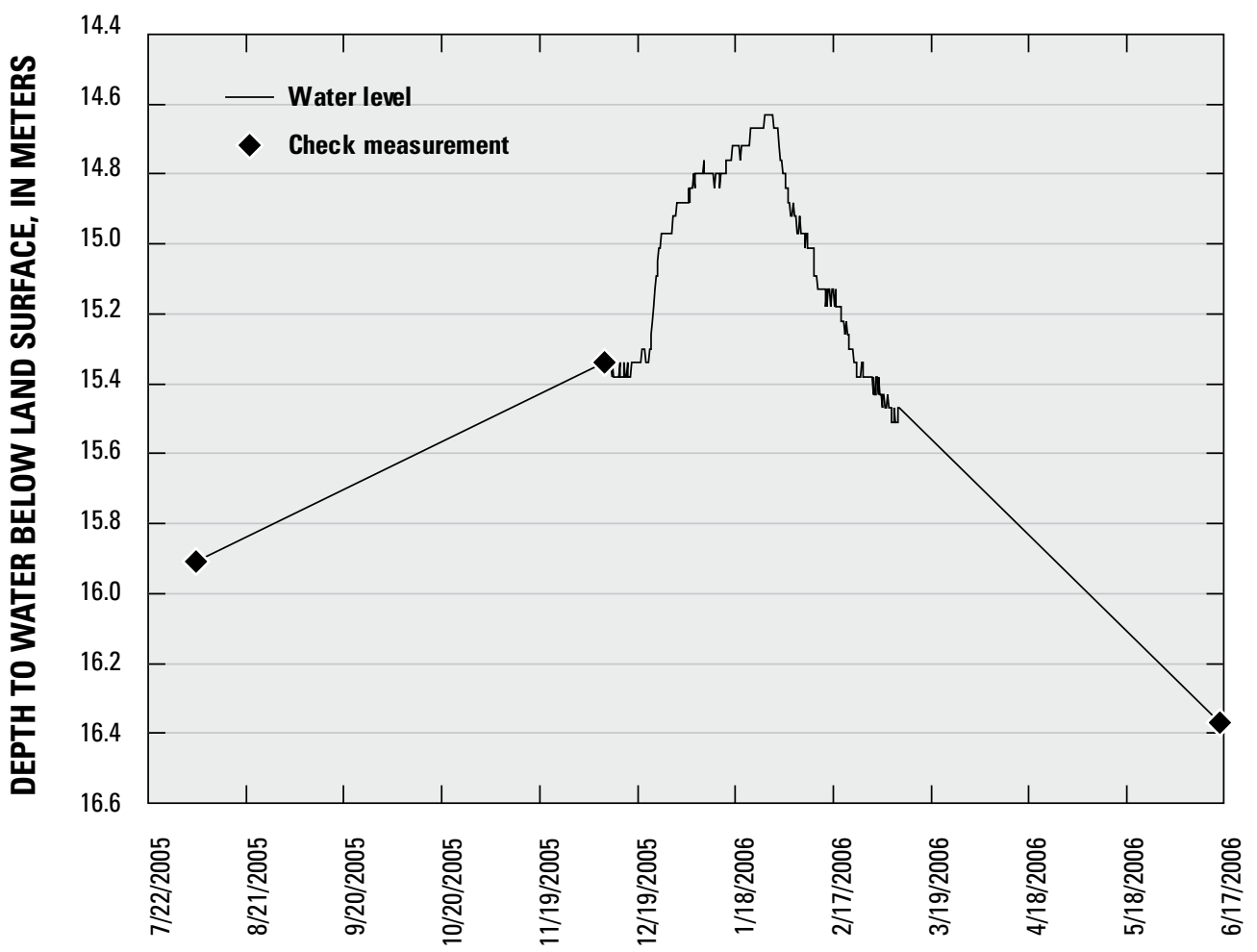

Figure 19. Water level in well FA93, Ribeira Paul Basin, August 2005 through June 2006. 
well is so close to the stream, however, it may not be suitable for evaluating regional ground-water levels.

FA57 is the only other well in the Ribeira Paul Basin. It has an installed submersible pump and, thus, no access for water-level measurements. The original FA57 drillers' log reported a depth to water of $1.60 \mathrm{~m}$ below land surface $(80 \mathrm{~m})$ on August 17, 1993. Assuming steady-state conditions in the basin (no substantial change in ground-water levels with time), a horizontal hydraulic gradient between the FA57 and FA93 wells of 0.05 can be estimated on the basis of water-level altitudes of $78 \mathrm{~m}$ at FA57 and $4 \mathrm{~m}$ at FA93, and a distance of 1,400 meters between the two sites. This is similar to groundwater hydraulic gradients reported for a basin in western Santiago having similar altitudes, geology, and precipitation (Barmen and others, 1984).

\section{Water Quality and Environmental Tracers}

The specific conductance of ground water in the Ribeira Paul Basin varies between 190 and $710 \mu \mathrm{S} / \mathrm{cm}$ (tables 3, 5). The lowest specific-conductance values (about $200 \mu \mathrm{S} / \mathrm{cm}$ ) were measured at the Tabulera, Zeagrios \#4 and Zeagrios \#5 sites. At $840 \mathrm{~m}$, Tabulera is the highest-altitude spring measured in the study (fig. 7) and discharges from the base of a thick sequence of basalt. Zeagrios \#4 and \#5 are sites along a spring-fed stream at an altitude of about $690 \mathrm{~m}$ (the actual spring discharge location is not accessible because of the steep terrain). The highest specific-conductance value $(710 \mu \mathrm{S} / \mathrm{cm})$ was measured at well FA93 at an altitude of $20 \mathrm{~m}$, the lowestaltitude ground-water sampling point in the basin. In general, the specific-conductance value of ground water increases with decreasing altitude and proximity to the ocean. This is likely caused by (1) irrigation and wastewater return flow in the streams, (2) recharge to the lower-altitude springs from highersalinity precipitation and sea spray closer to the ocean, or (3) longer flow paths and residence times.

Ground-water $\mathrm{pH}$ and temperature ranges in the Ribeira Paul Basin are 7.0 to 7.8 and $18.9^{\circ} \mathrm{C}$ to $24.0^{\circ} \mathrm{C}$, respectively (table 5). These measurements were taken in water from wells and springs that discharge directly from the subsurface and do not include water from spring-fed streams where mixing with the atmosphere would affect these parameters. These values are similar to those of ground water from the other two study basins and do not indicate upwelling geothermal sources of water. As with specific conductance, both $\mathrm{pH}$ and temperature show altitude trends: $\mathrm{pH}$ generally increases with altitude and temperature generally decreases with altitude, as expected from the temperature lapse rate. As with the Mosteiros Basin, the relatively high dissolved-oxygen concentration of 3.0 to $7.5 \mathrm{mg} / \mathrm{L}$ (38 to 88 percent saturation) indicate oxidized conditions within the aquifer and the lack of substantial bacterial decay of organic matter. Measured total dissolved-gas pressure values range from 689 to $777 \mathrm{~mm} \mathrm{Hg}$ and are generally similar to barometric pressure measurements at each site (694 to $762 \mathrm{~mm} \mathrm{Hg}$ ), indicating little entrapped (excess) air or gas production in the aquifer. The range of values for both total dissolved-gas pressure and barometric pressure in the Ribeira Paul Basin is larger than that of the other two basins because of the larger difference in altitude of the measured groundwater sites.

The stable-isotope ratios of ground water from the Ribeira Paul Basin generally follow the global meteoric water line (fig. 15), with the most-depleted $\delta^{18} \mathrm{O}$ and $\delta^{2} \mathrm{H}$ values of -29.1 and -4.93 permil, respectively, for the Tabulera spring (highest-altitude site) and the least-depleted $\delta^{18} \mathrm{O}$ and $\delta^{2} \mathrm{H}$ values of -13.7 and -3.19 permil, respectively, for well FA57 (lower in the basin). Precipitation samples during a 3-day rain event in late November 2005 were collected by U.S. Peace Corps volunteers in and near the Ribeira Paul Basin for stable-isotope analyses. One sample was collected in Vila das Pombas at the mouth of Ribeira Paul and two others were collected in nearby Ribeira Grande, along the coast about $20 \mathrm{~km}$ to the northwest of Vila das Pombas. The two Ribeira Grande samples plot along the meteoric water line but are generally more enriched than the ground-water samples from Ribeira Paul, likely because of the lower altitude of the precipitation-collection site compared to the ground-water sites. The Vila das Pombas sample is very isotopically depleted $\left(\delta^{18} \mathrm{O}\right.$ of -4.63 permil and $\delta^{2} \mathrm{H}$ of -32.1 permil; table 5, fig. 15) but also shows an evaporative shift off the meteoric water line, possibly caused by evaporation occurring between the precipitation event and sample placement in a sealed container.

Like Mosteiros, most of the dissolved gases in groundwater samples from the Paul Basin are of atmospheric origin, as indicated by the close comparison of measured and theoretical concentrations of the individual gases and small amounts of excess air $\left(\leq 0.0015 \mathrm{~cm}^{3} / \mathrm{g}\right)$. Calculated most-probable recharge temperatures range from $13-21^{\circ} \mathrm{C}$ for the springs and wells of Ribeira Paul Basin. The coolest recharge temperatures were $13^{\circ} \mathrm{C}$, measured at the Dragueiro \#1 spring and well FA57 (table 5). The warmest recharge temperatures were more than $20^{\circ} \mathrm{C}$, measured at the Passagem and Seladinha springs. Plotting $\operatorname{Tr}_{\text {min }} / \operatorname{Tr}_{\max }$ ranges for each sample against the temperature lapse curve (fig. 16) indicates recharge altitudes from about $900 \mathrm{~m}$ for Passagem and Seladinha to $1,300 \mathrm{~m}$ for Dragueiro \#1 and well FA57. These recharge altitudes are higher than the land-surface altitudes at all of these sites (20 to $840 \mathrm{~m}$ ), indicating that recharge to these wells and springs does not occur locally, but rather higher up in the watershed. The highest recharge altitude of 1,300 m indicates that recharge occurs either near the basin divide or in the La Cova caldera (fig. 7). It also indicates that the water-table altitudes in Paul basin are much higher than sea level, either as a result of horizontal flow barriers and compartmentalization or low permeability of the basalts. This is consistent with the numerous intrusive dikes visible in outcropping rocks, as well as the exposed tuffs and breccias in the center of the basin (fig. 8).

Two precipitation ${ }^{3} \mathrm{H}$ samples were collected in and near Ribeira Paul Basin during a rain event in late November 2005. These samples had ${ }^{3} \mathrm{H}$ concentrations of 1.1 to $1.4 \mathrm{TU}$ (table 6). Ground-water ${ }^{3} \mathrm{H}$ concentrations from samples collected in Paul Basin ranged from 0.2 to 1.7 TU. Tabulera was the only 
site having ${ }^{3} \mathrm{H}$ concentrations less than $0.3 \mathrm{TU}$, indicating that ground-water recharge to this spring occurred prior to the early 1950s. The other springs in Paul Basin had ${ }^{3} \mathrm{H}$ concentrations ranging from 0.5 to $1.2 \mathrm{TU}$. Water from wells FA57 and FA93 had ${ }^{3} \mathrm{H}$ concentrations of 0.9 to $1.7 \mathrm{TU}$.

${ }^{3} \mathrm{H} /{ }^{\beta} \mathrm{He}$ age dating was useful at five springs and one well in Ribeira Paul Basin: Tabulera, Dragueiro \#1, NA21, Passagem, Seladinha, and well FA93 (table 6). These sites indicate that ground water in Ribeira Paul is a mixture of waters recharged both pre- and post-1950s. Water collected from Tabulera had an apparent age of more than 50 years, indicating recharge prior to the 1950s. Water collected from Dragueiro \#1, NA21, Passagem, Seladinha, and FA93 all have apparent ages of less than 50 years, indicating recharge since the 1950s.

Compared with Mosteiros Basin, there was a much lesspronounced influence of mantle-derived helium on ground water in Ribeira Paul Basin. This is likely because of the much longer time since there was active volcanism on the island of Santo Antão. Only one well (FA57) showed the influence of terrigenic helium (fig. 17, table 6). The ${ }^{3} \mathrm{He}:{ }^{4} \mathrm{He}$ ratio of this ground-water sample was about 2.5 times the atmospheric ratio and ${ }^{4} \mathrm{He}$ was slightly above the atmospherically equilibrated concentration. Because of this terrigenic ${ }^{4} \mathrm{He}$ (fig. 18), ${ }^{3} \mathrm{H} /{ }^{3} \mathrm{He}$ age dating was not possible at this one site. Water at the other well in Ribeira Paul Basin (FA93) is assumed to be coming from the adjacent stream and fell as recent precipitation. The sample had no tritiogenic helium and a ${ }^{3} \mathrm{H}$ concentration of $1.3 \mathrm{TU}$, within the range of current precipitation tritium concentrations measured during this study. Because this young water comes from a well screened in shallow alluvium (total depth $=21 \mathrm{~m}$ ) and is adjacent to the stream, there is a high potential for anthropogenic contamination from upstream sources (nitrates, pathogenic bacteria). Although the water has low salinity, the measured specific-conductance value was higher than that measured at any other location in Ribeira Paul, possibly because of irrigation return flow or discharge of wastewater.

\section{Ribeira Fajã}

\section{Ground-Water Discharge}

The main source of ground-water discharge in the Ribeira Fajã Basin is from the Galleria Fajã tunnel. No natural springs or ground-water evapotranspiration occurs within the basin and there is currently no well production. As in the other basins, submarine discharge may be the dominant form of ground-water discharge from the Ribeira Fajã Basin, but this could not be evaluated during the study.

The 1,800-m-long Galleria Fajã tunnel was constructed during the 1980s to act as a ground-water drain and supply a steady source of water for agriculture and public supply. The tunnel begins at an altitude of about $250 \mathrm{~m}$ near the town of Fajã de Baixo. It trends southwest toward the upland areas of the basin (fig. 9) at a slope of about 1 percent. Water enters the upper end of the tunnel at Lombo Pelado, Cruz Roque, and Monte Gordo, with altitudes between 265 and $270 \mathrm{~m}$. Monte Gordo is the largest source, providing all of the culinary water and the majority of the irrigation water for the basin.

Construction of the Galleria Fajã tunnel began in 1980 under the supervision of the French government and was completed in 1986. The first discharge measurements were made in 1984 (fig. 20). Discharge rapidly increased to about $1,500 \mathrm{~m}^{3} / \mathrm{d}$ by late 1984 (Geoffray, 1985). No discharge measurements are available from May 1985 to September 1986; discharge likely exceeded $1,500 \mathrm{~m}^{3} / \mathrm{d}$ during this interval. Discharge rapidly decreased from late 1986 to late 1997 and has remained fairly constant through 2005 at about $400 \mathrm{~m}^{3} / \mathrm{d}$ (measured by Servicio Autonimo Fajã (SAF) and reported by Ministero de Ambiente e Agricultura, 2005). The USGS evaluated the accuracy of the flow-meter measurements reported by SAF for the combined flow from the Lombo Pelado, Cruz Roque, and Monte Gorde irrigation spring by making independent bucket and stop-watch discharge measurements of the four separate springs on the same date as a combined SAF measurement (December 13, 2005). In order to compare the total flow measurements using both techniques (bucket and stopwatch versus in-line flow meter), $60 \mathrm{~m}^{3} / \mathrm{d}$ (the amount of public-supply water) was added to the metered irrigation pipe flow of $370 \mathrm{~m}^{3} / \mathrm{d}$ measured by the SAF. There is no separate in-line instantaneous flow meter for measuring the public-supply portion of the Monte Gordo spring, so the $60 \mathrm{~m}^{3} / \mathrm{d}$ was calculated from a totalizing meter monthly flow calculation of the public-supply water reported by SAF (Ministero de Agricultura e Ambiente, written commun., 2005). This analysis results in a reported discharge of $430 \mathrm{~m}^{3} / \mathrm{d}$ for December 13 , 2005 , compared with a total measurement of $470 \mathrm{~m}^{3} / \mathrm{d}$ for the four separate spring sources within the galleria measured by the USGS (table 3). The 10-percent difference is within the uncertainty generally associated with both in-line flow meters and the bucket-and-stopwatch method.

The annual precipitation at the Cachaço station shows that the decrease in Galleria Fajã discharge during 1986-97 was not caused by drought. The average annual precipitation during this period $(320 \mathrm{~mm})$ was about the same as the average precipitation of $340 \mathrm{~mm}$ during the entire period (19842005) of Galleria Fajã discharge measurements. The Galleria acts as a large ground-water drain for the Ribeira Fajã Basin and the large decline in discharge from 1986 through 1997 was likely a result of dewatering of the aquifer in response to the construction of the tunnel. This is supported by historical spring discharge observations and water-level data from observation wells FN12, FN21, FN39, and FN41 (all drilled between 1978 and 1980; table 4) showing rapidly declining ground-water levels. According to local accounts (Armindo Basilio, Servicio Autonomo de Agua, Ribeira Brava, oral commun., 2005), a fairly large perennial spring discharged from the sea cliffs north of the town of Queimada (fig. 9) prior to construction of the Galleria, but went dry soon after completion of the tunnel. There are no accounts of any other surface 


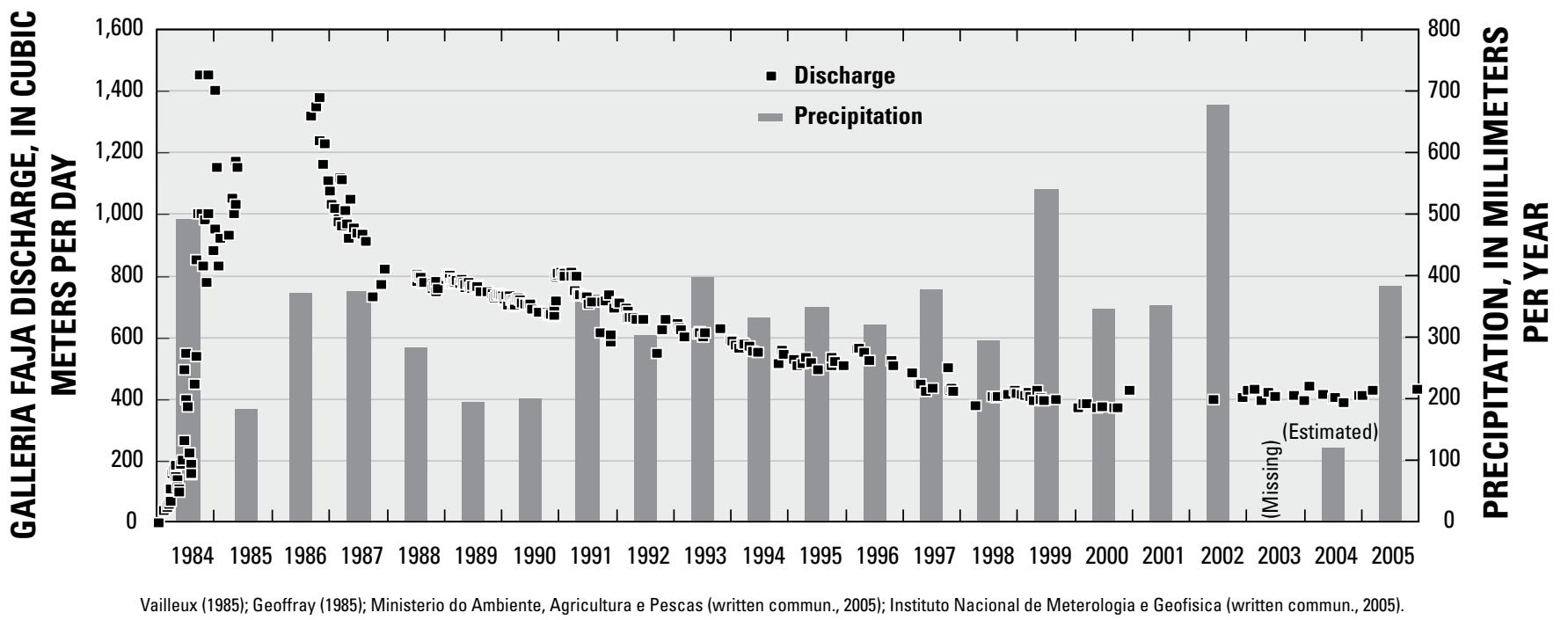

Figure 20. Galleria Fajã discharge and annual precipitation at nearby Posto Cachaço, Ribeira Fajã Basin, $1984-2005$.

water, besides ephemeral flow after large precipitation events, occurring in the Ribeira Fajã Basin prior to the construction of Galleria Fajã.

Wells FN41 and FN21 are located about $820 \mathrm{~m}$ and 1,700 $\mathrm{m}$, respectively, from the main Monte Gordo spring at the head of the tunnel (fig. 9). The hydrographs of these wells (figs. 21, 22) show ground-water levels declining rapidly beginning in 1985. Well FN41 went dry in November 1986 and well FN21 went dry in February 1987. Well FN39 is located about 4,000 $\mathrm{m}$ from the Monte Gordo spring. Between 1982 and 1998, water levels in this well decreased by $20 \mathrm{~m}$ (from about $53 \mathrm{~m}$ to about $73 \mathrm{~m}$ below land surface; table 4 ). The loss of flow at the Queimada spring and the rapid water-level decline in these three observation wells is directly attributed to dewatering caused by the completion of the Galleria Fajã tunnel. Their response to the Galleria Fajã also indicates that, despite the fairly complex geology of the basin (fig. 10), the wells, spring, and tunnel are all hydraulically connected within the same aquifer system.

The average annual volume of precipitation falling within the Ribeira Fajã Basin is estimated to be about $5 \times 10^{6}$ $\mathrm{m}^{3}$. This is based on an average basin altitude of $483 \mathrm{~m}$, an interpolated annual precipitation value of $300 \mathrm{~mm}$, and a basin area of $16 \mathrm{~km}^{2}$. The interpolated $300-\mathrm{mm}$ annual precipitation is based on a linear interpolation $\left(r^{2}=0.77\right)$ of the 1996-2002 average precipitation for the three precipitation stations in the Ribeira Fajã Basin. For the water-budget estimate, Galleria Fajã is assumed to be the only measurable ground-water discharge from the basin, with a flow of $400 \mathrm{~m}^{3} / \mathrm{d}$ (fig. 20). The total measurable annual discharge from the basin, not including submarine discharge, is estimated to be about $150,000 \mathrm{~m}^{3}$ per year.

\section{Ground-Water Levels}

Ground-water levels were measured during this study in Ribeira Fajã Basin only at well FN39. An attempted waterlevel measurement by the INGRH at well FN41 on March 8,2006 , confirmed that this well remains dry. A non-vented transducer, barometer, and data logger were installed in December 2005 to continuously record ground-water levels and barometric pressure in well FN39. Small water-level fluctuations of less than $0.1 \mathrm{~m}$ occurred between December 2005 and March 2006 (fig. 23), much less than the 20-m decline during the 1980s and 1990s. Since 1998, water levels have remained fairly constant in well FN39 (table 4). Both the steady ground-water levels and the relatively constant tunnel discharge since 1998 indicate that a new ground-water equilibrium in the basin has been established in response to construction of the Galleria Fajã.

Because observation wells FN41 and FN39 are aligned along the northeast-trending axis of the Ribeira Fajã Basin, it is likely that they generally lie along a ground-water flow path. The pre-Galleria horizontal hydraulic gradient can be calculated by dividing the difference in the water-table altitude at these two wells by their distance apart. In 1980, the watertable altitudes in wells FN41 and FN39 were about 316 m and $39 \mathrm{~m}$, respectively, yielding a water-level difference of $277 \mathrm{~m}$. The distance between the two wells is about $3,450 \mathrm{~m}$, resulting in a horizontal hydraulic gradient of 0.08 . Assuming the 270-m altitude of the Monte Gordo spring at the head of the Galleria Fajã represents the water table at that location, a similar calculation can be made of the post-Galleria horizontal hydraulic gradient. The recently measured water-level altitude at FN39 is $17 \mathrm{~m}$, based on a land-surface altitude of $90 \mathrm{~m}$ and a depth to water of $73 \mathrm{~m}$. Therefore the water-level difference between the Monte Gordo spring and FN39 is about $253 \mathrm{~m}$. The distance between the spring and well is about $3,970 \mathrm{~m}$, yielding a horizontal hydraulic gradient of 0.06 . This indi- 


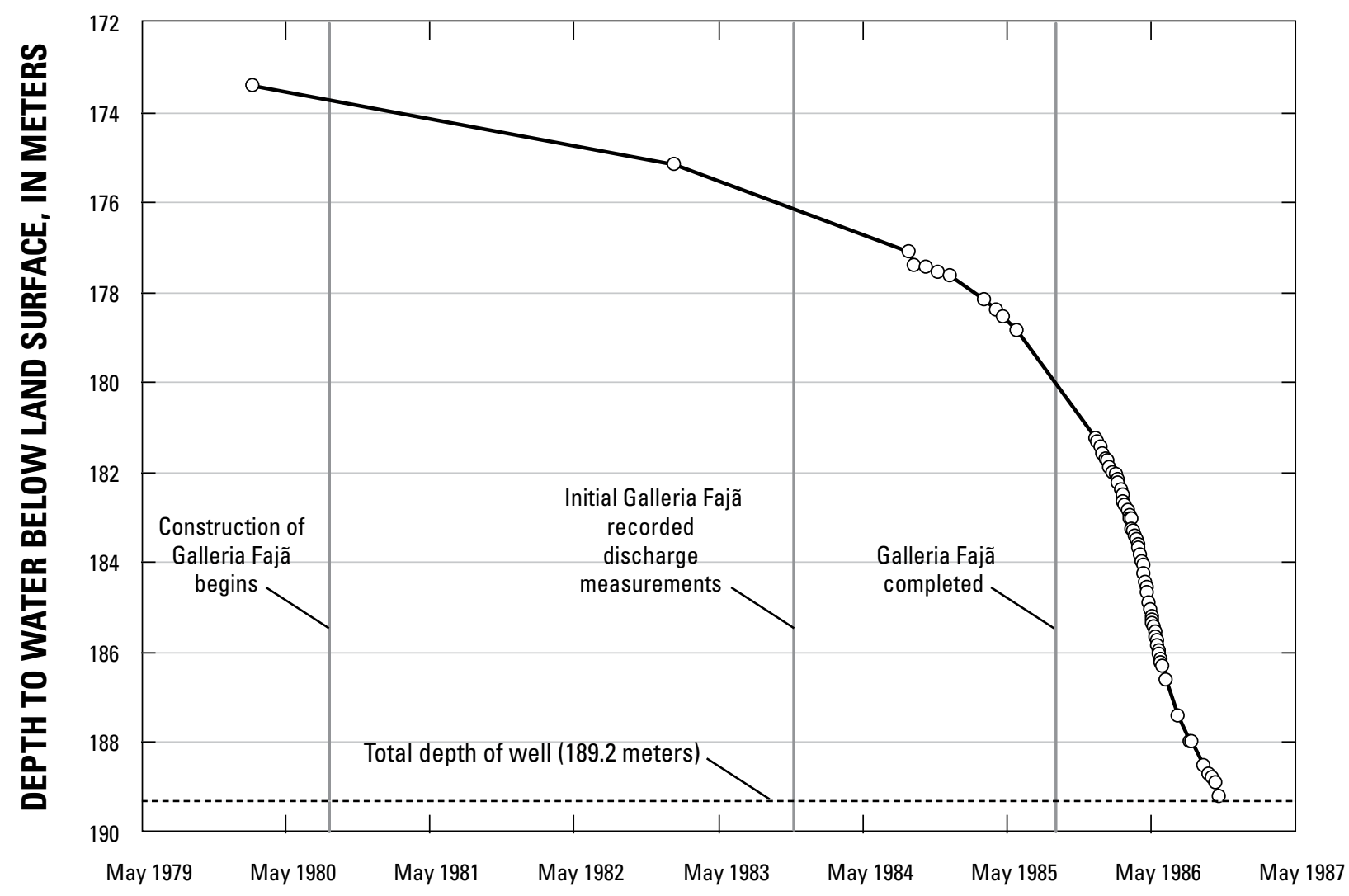

Figure 21. Water level in well FN41, Ribeira Fajã Basin, 1980-86.

cates that the dewatering associated with the Galleria Fajã has resulted in a less-steep hydraulic gradient in the lower twothirds of the Ribeira Fajã Basin. The opposite is probably true for the upper one-third of the basin - the hydraulic gradient in this upland area has likely increased since the construction of the Galleria. Both the pre- and post-Galleria horizontal hydraulic gradients are slightly higher than the gradient measured in the lower Ribeira Paul Basin.

Galleria Fajã discharge measurements and water-level drawdown in wells FN21 and FN41 during the mid-1980s were evaluated to estimate aquifer hydraulic properties in Ribeira Fajã. Two alternative methods were used. A transient numerical ground-water flow model of the aquifer yielded approximate values for transmissivity and storage of about $20 \mathrm{~m}^{2} / \mathrm{d}$ and 0.01 , respectively (K. Halford, U.S. Geological Survey, written commun., 2006). A multiple-well Theis curvematching method resulted in a transmissivity value of about 2 $\mathrm{m}^{2} / \mathrm{d}$ and storage values between 0.003 and 0.009 (E. Weeks, U.S. Geological Survey, written commun., 2006). Assuming an aquifer thickness of $30 \mathrm{~m}$, this range in transmissivity is equal to a hydraulic-conductivity range of 0.07 to $0.7 \mathrm{~m} / \mathrm{d}$, on the low end of the reported range of permeable basalts $(0.1$ to $1,000 \mathrm{~m} / \mathrm{d}$; Freeze and Cherry, 1979) and similar to values reported for thick ponded Hawaiian basalts (Gingerich, 1999; Izuka and Gingerich, 1998). This indicates that the water table in Ribeira Fajã would have a steep gradient and be located at a substantial altitude above land surface. This is consistent with water-table altitudes, calculated from land surface and depthto-water measurements (table 4), of about 10 to $200 \mathrm{~m}$.

\section{Water Quality and Environmental Tracers}

The measured specific-conductance value of ground water in the Galleria Fajã spring tunnel decreases with increasing distance from the tunnel entrance: $550 \mu \mathrm{S} / \mathrm{cm}$ at the Lombo Pelado spring, $440 \mu \mathrm{S} / \mathrm{cm}$ at the Cruz Roque spring, and $380 \mu \mathrm{S} / \mathrm{cm}$ at the Monte Gordo spring (table 5). Measured specific conductance in water from well FN39 was $500 \mu \mathrm{S} / \mathrm{cm}$. Measured ground-water $\mathrm{pH}$ was 7.8 to 8.3 at the Monte Gordo spring and 7.6 at FN39. Ground-water temperature was $21.3^{\circ} \mathrm{C}$ at the Monte Gordo spring and $23.9^{\circ} \mathrm{C}$ at FN39. These values are similar to those of ground water from the other two study basins and do not indicate upwelling geothermal sources of water. Like the other two basins, relatively large dissolvedoxygen concentrations (5.7 to $7.9 \mathrm{mg} / \mathrm{L} ; 68$ to 89 percent saturation) indicate oxidized conditions within the aquifer and the lack of substantial bacterial decay of organic matter. Measured total dissolved-gas pressure values were $737 \mathrm{~mm} \mathrm{Hg}$ at the Monte Gordo spring and $760 \mathrm{~mm} \mathrm{Hg}$ in well FN39. These values are nearly identical to the barometric pressure measurements at each site ( 737 to $755 \mathrm{~mm} \mathrm{Hg}$ ), indicating little entrapped (excess) air or gas production in the aquifer. 


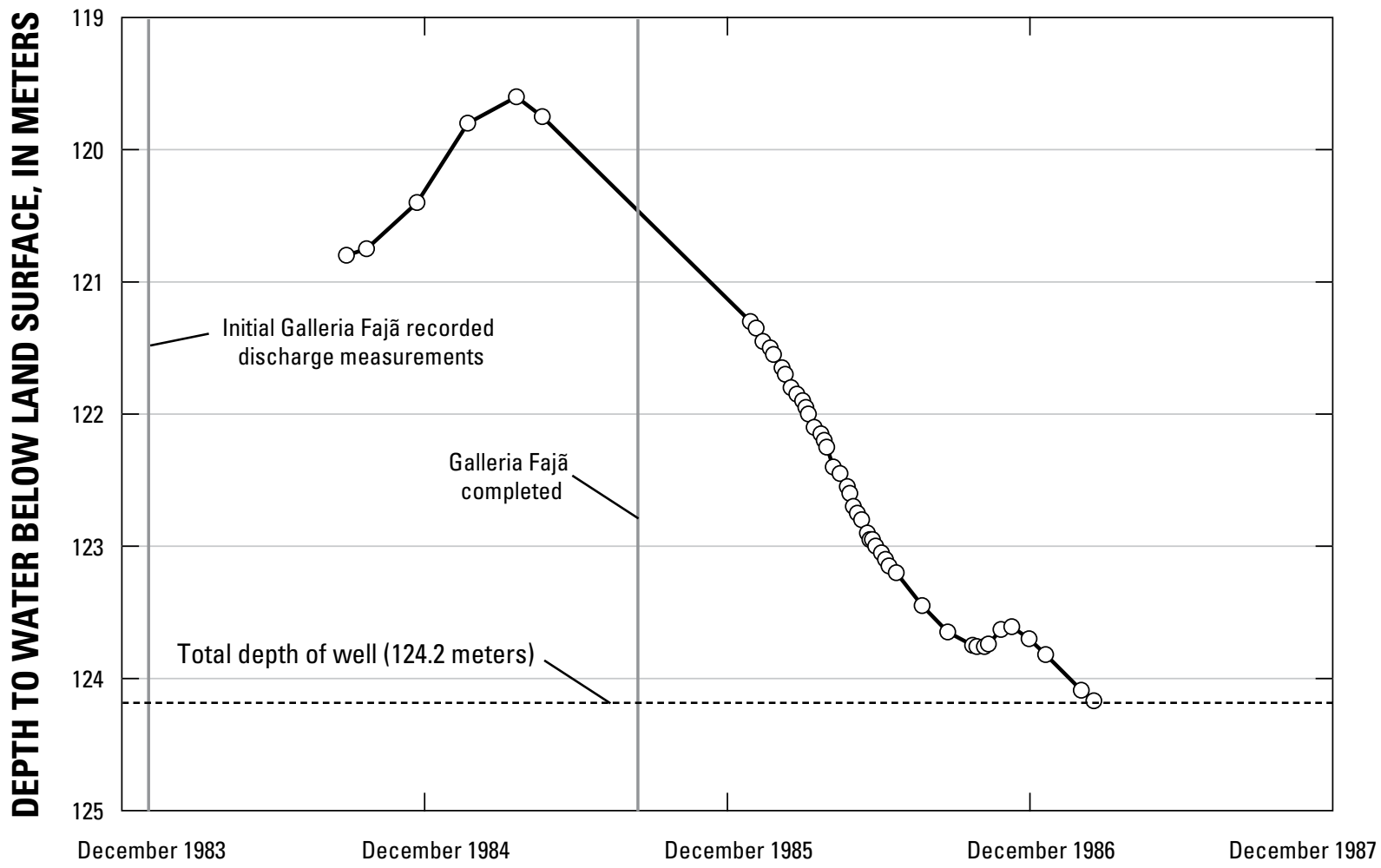

Figure 22. Water level in well FN21, Ribeira Fajã Basin, 1984-87.

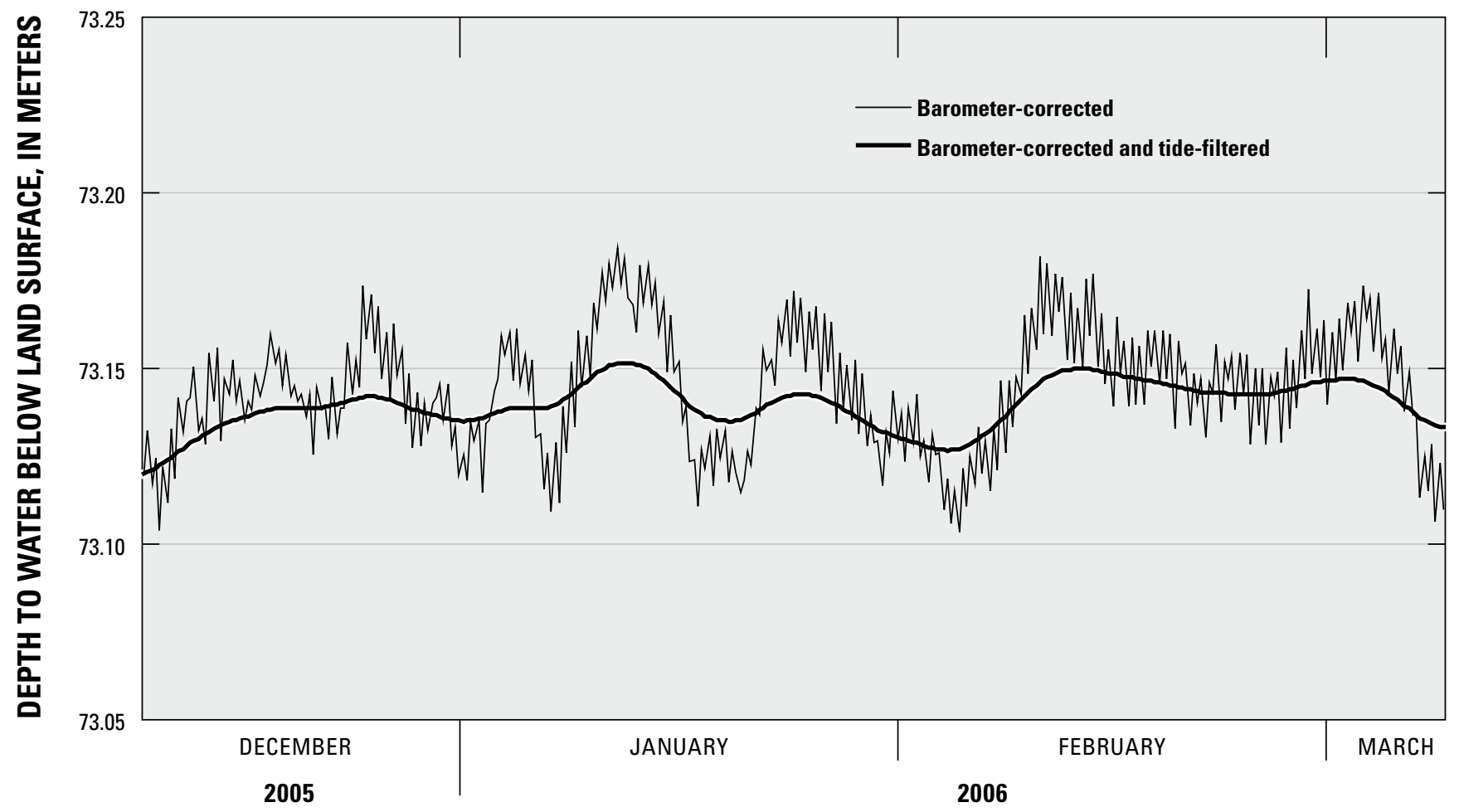

Figure 23. Water level in well FN39, Ribeira Fajã Basin, December 2005 through March 2006. 
One precipitation sample was collected for stable-isotope analyses within Ribeira Fajã Basin for this study, with $\delta^{18} \mathrm{O}$ and $\delta^{2} \mathrm{H}$ values of -0.6 and -5.0 permil, respectively. Stableisotope concentrations for São Nicolau precipitation were previously reported for the 10 most important precipitation events of 1981, with $\delta^{18} \mathrm{O}$ values from -1.2 to -4.8 permil and $\delta^{2} \mathrm{H}$ values from -2 to -30 permil (Barmen and others, 1990). The stable isotope ratios of ground water from Galleria Fajã tunnel and well FN39 both plot along the meteoric water line within a very tight range, indicating a similar source of precipitation recharging the aquifer for these two locations (fig. 15). Values of $\delta^{18} \mathrm{O}$ range from -3.84 to -4.04 permil and values of $\delta^{2} \mathrm{H}$ range from -19.4 to -21.6 permil. Except for two samples (FF06 in the Mosteiros Basin and Tabulera Spring in the Ribeira Paul Basin), the stable-isotope ratios of ground water from the Ribeira Fajã Basin are more depleted than the other two basins, even though the average altitude of the Ribeira Fajã Basin is much lower than the average altitude of both the Mosteiros and the Ribeira Paul Basins (table 1). This indicates either that the majority of recharge in the Ribeira Fajã Basin is from higher-altitude source precipitation or the atmospheric patterns result in more isotopically depleted air masses entering the basin.

Like Mosteiros and Paul, most of the dissolved gases in ground-water samples from the Ribeira Fajã Basin are of atmospheric origin, as indicated by the close comparison of measured and theoretical concentrations of the individual gases and small quantities of excess air $\left(\leq 0.001 \mathrm{~cm}^{3} / \mathrm{g}\right.$; table 5). Calculated most-probable recharge temperatures are $16^{\circ} \mathrm{C}$ for the Galleria Fajã (Monte Gordo spring) and $22^{\circ} \mathrm{C}$ for well FN39. Plotting $\operatorname{Tr}_{\text {min }} / \operatorname{Tr}_{\max }$ ranges for each sample against the temperature lapse curve (fig. 16) indicates recharge altitudes of $900 \mathrm{~m}$ for the Galleria Fajã and 700 m for the FN39 well. These recharge altitudes are higher than the land-surface altitudes of the two sites (270 and $90 \mathrm{~m}$, respectively), indicating that recharge does not occur locally, but rather higher up in the watershed (fig. 9). Like the other basins, this indicates that water-table altitudes in Ribeira Fajã Basin are much higher than sea level, likely caused by horizontal flow barriers and the low permeability of the basalts. This is consistent with the numerous intrusive dikes visible along the walls of the Galleria Fajã and the small values of hydraulic conductivity for the basalt determined by analyzing aquifer drawdown associated with completion of the tunnel.

Ground-water ${ }^{3} \mathrm{H}$ concentrations from samples collected in Ribeira Fajã Basin were all $\leq 0.3$ TU, indicative of groundwater recharge occurring prior to the early 1950s. Both dissolved-gas samples collected in Galleria Fajã display evidence of terrigenic helium with $\mathrm{R} / \mathrm{R}_{\mathrm{a}}$ values greater than 3.0 (fig. 17, table 6). Because of this terrigenic helium (fig. 18), ${ }^{3} \mathrm{H} /{ }^{3} \mathrm{He}$ age dating of the Galleria Fajã samples was not possible. Water from well FN39, however, does not appear to be influenced by terrigenic helium; the estimated ${ }^{3} \mathrm{He}_{\text {trit }}$ concentration of 0 to 8 TU results in an apparent age of greater than 50 years, indicating that recharge likely occurred prior to the 1950 s.

\section{Measured Ground-Water Discharge as a Percentage of Precipitation}

As determined from measured ground-water discharge in the Mosteiros Basin, only about 1 percent of precipitation discharges from the aquifer as well withdrawals and spring flow. If a substantial part of the precipitation falling within the Cha das Caldeiras Cova caldera recharges the Mosteiros Basin ground-water system, this ratio of measured ground-water discharge to precipitation would be even less. Assuming steadystate conditions where ground-water recharge equals groundwater discharge, this infiltration ratio does not compare closely to values based on a previously published equation by Vailleux and Bourguet (1974) for estimation of ground-water infiltration in Cape Verde:

$$
I=0.25(P-300)
$$

where:

$I \quad$ is average annual infiltration in $\mathrm{mm} / \mathrm{yr}$, and

$P \quad$ is average annual precipitation, in $\mathrm{mm} / \mathrm{yr}$.

Applying equation 6 to Mosteiros Basin results in an infiltration rate of $73 \mathrm{~mm} / \mathrm{yr}$, or 12 percent of the estimated average annual precipitation of $590 \mathrm{~mm} / \mathrm{yr}$ for the basin. The likely reason for this large discrepancy is that actual net infiltration and ground-water recharge rates are much larger than indicated by measured ground-water discharge, but much of this recharge is lost as unmeasured submarine outflow to the ocean. This prospect of large (and currently unexploited) submarine discharge was first proposed by Kallrén and Schreiber (1988).

For the Ribeira Paul Basin, about 15 percent of the average annual $1.0 \times 10^{7} \mathrm{~m}^{3}$ volume of precipitation falling within the basin was measured as ground-water discharge. A similar infiltration rate of about 13 percent $(88 \mathrm{~mm} / \mathrm{yr})$ of the annual precipitation for Ribeira Paul Basin was calculated by using equation 6 . The actual percent of precipitation within the basin that recharges the aquifer and then discharges to wells and springs, however, may be lower than 15 percent if a substantial part of the precipitation falling within the $\mathrm{La}$ Cova caldera also flows into the aquifer beneath the Ribeira Paul Basin. Alternatively, if there is substantial ground-water evapotranspiration (agricultural or natural flora consumptive use) or submarine outflow of ground-water from the basin, the percentage of precipitation recharging the aquifer may be higher than 15 percent.

For the Ribeira Fajã Basin, about 3 percent of the average annual $5 \times 10^{6} \mathrm{~m}^{3}$ volume of precipitation falling within the basin was measured as ground-water discharge. This estimated percent of precipitation is likely too low for two reasons: (1) the estimated basin-average precipitation value of $300 \mathrm{~mm} / \mathrm{yr}$ may be higher than the long-term average because the 19612005 average annual precipitation at the Cachaço station was $294 \mathrm{~mm}$, compared with the 1996-2002 average of $415 \mathrm{~mm}$; 
and (2) there likely is additional ground-water discharge as subsurface outflow directly to the ocean that could not be quantified during this study. The ground-water infiltration estimated for Ribeira Fajã Basin by using equation 6 (Vailleux and Bourguet, 1974), however, is even lower (0 mm/yr). Equation 6 assumes that no ground-water infiltration occurs in areas receiving less than $300 \mathrm{~mm}$ annual precipitation. However, if the Ribeira Fajã basin was divided into distinct precipitation zones rather than using one mean basin average, the equation would predict some infiltration in the higher-altitude parts of the basin where precipitation likely exceeds $300 \mathrm{~mm} / \mathrm{yr}$.

In summary, measured ground-water discharge as a percent of precipitation was about one percent for the Mosteiros Basin, three percent for the Ribeira Fajã Basin, and fifteen percent for the Ribeira Paul Basin. These are large differences, particularly between the Mosteiros and Ribeira Paul Basins, which receive similar average annual rainfall. Actual net infiltration and recharge as a percentage of precipitation may be smaller in Mosteiros Basin because of the smaller amount of soil cover, which results in less water retention and more runoff during storms. However, a large amount of unmeasured submarine ground-water discharge from the Mosteiros Basin also would cause this apparently small net-infiltration percentage. The large regional spring discharge near the high-tide mark at Monte Vermelho may be evidence for this alternative hypothesis. The steeper topographic gradients and occurrence of low permeability dikes, tuffs, and breccias in the Ribeira Paul Basin may force a higher percentage of ground water to discharge at springs, which may result in a smaller proportion of ground-water discharge as submarine outflow. Similarly, the smaller apparent net infiltration and recharge in the Mosteiros Basin as compared with Ribeira Fajã seems to be an enigma, particularly since the Mosteiros Basin receives about twice the amount of average annual precipitation and has a more northerly exposure. In order to determine if actual net infiltration rates are lower in Mosteiros because of its steeper topographic gradients and smaller amount of soil cover, further data collection and analysis is needed.

\section{Challenges in Evaluating Ground- Water Conditions in the Three Basins}

Evaluating baseline ground-water conditions in the three Cape Verde watersheds has a certain degree of uncertainty because of various data limitations. This study and previous work have provided much information on precipitation, ground-water levels, some ground-water discharge fluxes (wells and springs), recharge source altitudes, and groundwater age. However, there are no simple methods for evaluating other ground-water budget components, such as net infiltration and recharge, changes in ground-water storage, plant evapotranspiration and consumptive use (Paul Basin only), and submarine ground-water discharge without substantial amounts of additional data and analysis. Contributing to additional uncertainty is the limited understanding within each basin of geology, soil permeability, and complex precipitation patterns caused by topography and wind patterns. Of particular concern are:

1. The scarcity of wells and historical water-level and precipitation information. Although dedicated monitoring wells were available in Mosteiros Basin, the Ribeira Paul and Ribeira Fajã Basins each only had one well temporarily available for monitoring.

2. The 3-to 6-month period of continuous water-level measurements made in monitoring wells during this study. This short time was insufficient for evaluation of longer-term responses to natural (seasonal, multiyear) climatic cycles.

3. The spatial distribution of existing observation wells. These wells were not uniformly distributed within the basins, but were located only at low altitudes near the coast. Consequently, water levels from two of the three continuous recorder wells displayed strong tidal effects.

4. The lack of precipitation data after 2002 for evaluating ground-water response to climatic change in Ribeira Fajã and the lack of data after 2004 for Mosteiros and Ribeira Paul.

5. Spring and spring-fed stream-discharge measurements made in Ribeira Paul shortly after the rainy season. Total spring discharge for the Ribeira Paul Basin is an important value for evaluating baseline ground-water conditions. Yearly measurements during base-flow conditions (prior to the rainy season) would reduce the uncertainty in this ground-water budget component.

6. The presence of terrigenic helium in ground-water samples because of recent volcanic activity. This prevented ${ }^{3} \mathrm{H} /{ }^{3} \mathrm{He}$ age-dating at some ground-water sites. At these sites, tritium could only be used as a general indicator of either modern (post-1950s) or older (pre1950s) recharge. Additional age-dating techniques, such as CFCs and ${ }^{14} \mathrm{C}$ were outside the scope of this study.

\section{Summary and Conclusions}

This study assessed baseline ground-water conditions in the Mosteiros, Ribeira Paul, and Ribeira Fajã Basins of Cape Verde, on the basis of existing and new data collection. This information is needed to evaluate long-term changes in ground-water resources or water-quality associated with future development. The study initially focused on measuring current ground-water levels in each basin. Because of the scarcity of monitoring wells in all three basins, however, other hydrologic indicators also were examined to understand baseline ground-water conditions for all three basins. These indicators included the compilation of historical ground-water level 
information, the estimation of ground-water budgets on the basis of discharge measurements, field ground-water quality measurements to evaluate salt-water intrusion, and laboratory analysis and interpretation of environmental tracers to evaluate recharge altitude and ground-water age.

In the Mosteiros Basin, the measured discharge from wells and springs of about $600 \mathrm{~m}^{3} / \mathrm{d}$ represents about one percent of the precipitation. Therefore, unmeasured submarine outflow is likely an important form of ground-water discharge from the basin. Intercepting this discharge could provide an additional source of water for future development. Mount Vermelho spring accounts for most of the $600 \mathrm{~m}^{3} / \mathrm{d}$ of the measured discharge from the basin. Half of this is assumed to be lost to the sea. However, no historical records exist for evaluating the long-term effects of pumping or climate on discharge from this spring. The other source of discharge, well withdrawals along the narrow coastal plain, appears to have been fairly steady at about $100 \mathrm{~m}^{3} / \mathrm{d}$. While demand for water has increased, well pumping from the two existing production wells has not increased because of salt-water intrusion problems. If the existing production wells are pumped continuously, the water becomes brackish (exceeding 1,000 mg/L dissolved solids). This is consistent with a specific-conductance depth profile of monitoring well FF06, which showed values exceeding $10,000 \mu \mathrm{S} / \mathrm{cm}$ (equivalent to about 5,500 to $7,500 \mathrm{mg} / \mathrm{L}$ dissolved solids) at depths greater than $7 \mathrm{~m}$ below the water table. An important metric for evaluating the effects of additional pumping would be to monitor salinity in the observation and production wells of the coastal plain. Water levels monitored continuously in Mosteiros at well FF07 from December 2005 through March 2006 showed a $0.2 \mathrm{~m}$ decline. Reasons for this small decline could not be determined; longer periods of water-level records are needed to discern whether this is a climatic response or caused by nearby pumping. No historical water-level records exist for evaluating longerterm ground-water trends in Mosteiros Basin. Ground-water age dates, stable-isotope concentrations, and dissolved-gas recharge temperatures from Mosteiros Basin indicate that recharge to the wells in Mosteiros mostly occurred more than 50 years ago and at much higher altitudes in the aquifer. This suggests that it may take many years for artificial recharge to result in a beneficial impact on the aquifer in areas where the agricultural projects are implemented.

Ribeira Paul Basin has more abundant ground-water resources than the other two basins. Measured ground-water discharge accounts for about 12 percent of the precipitation falling within the basin. The $4,000 \mathrm{~m}^{3} / \mathrm{d}$ of measured discharge (mostly from springs and spring-fed streams) is based on an inventory at the end of the rainy season and does not include ground-water evapotranspiration. Base flow spring/stream discharge and evapotranspiration measurements at the end of the dry season would provide more accurate estimates of available ground-water resources; the Ribeira Cha João Vaz constriction point and at the northern springs would be ideal locations for these comparative discharge measurements. Only a small amount of water (about $200 \mathrm{~m}^{3} / \mathrm{d}$ ) is currently pumped out of wells. Water levels at the monitoring well appear to be strongly affected by streamflow in the nearby Ribeira Paul. The water level in this well rose by $1.3 \mathrm{~m}$ between August 2005 and January 2006, then declined $1.8 \mathrm{~m}$ by June 2006. This seasonal variation is associated with flow in the nearby ephemeral stream channel. Because of this strong surfacewater influence on the water level, this well may not be suitable for evaluating long-term regional ground-water conditions. Ground-water age dates, stable-isotope concentrations, and dissolved-gas recharge temperatures from the Ribeira Paul Basin indicate a wide variation in recharge source altitudes, ground-water flow paths, and ground-water residence times Most-probable recharge altitudes estimated from dissolved-gas recharge temperatures range from 900 to $1,300 \mathrm{~m}$, indicating that recharge generally occurs at altitudes much higher than the ground-water discharge points. Ground-water ages range from pre-1950s to modern, indicating both short, quick flow paths from nearby recharge and long, slow flow paths from distant recharge. This combination of differing flow paths is probably caused by the steeply incised topography of the basin, the relatively high precipitation rates, and the horizontal flow barriers associated with breccia deposits and intrusive dikes. Because of this complexity, detailed water budget and soil permeability investigations are needed for evaluating the feasibility of localized artificial recharge.

Ribeira Fajã is the driest basin, receiving only about half of the average annual precipitation of the other two basins. The only measurable ground-water discharge is from Galleria Fajã tunnel, currently flowing at about $400 \mathrm{~m}^{3} / \mathrm{d}$. As with the Mosteiros Basin, it is likely that unmeasured submarine outflow is the dominant form of ground-water discharge from the basin. Historical water-level records from Ribeira Fajã indicate very large ground-water declines of tens of meters during the 1980s and early 1990s. This probably was associated with dewatering of the Galleria Fajã tunnel, whose discharge peaked at more than $1,400 \mathrm{~m}^{3} / \mathrm{d}$ in the mid-1980s. More-recent data indicate that ground-water levels in Ribeira Fajã have reached a new equilibrium, remaining fairly constant since the late 1990s. No substantial water-level changes were observed between December 2005 and March 2006 at the monitoring well in Ribeira Fajã. Ground-water age dates, stable-isotope concentrations, and dissolved-gas recharge temperatures all indicate that recharge to the Galleria occurred more than 50 years ago and at much higher altitudes (about $900 \mathrm{~m}$ ) in the aquifer. Analysis of water-level declines associated with the Galleria Fajã dewatering in the 1980s indicates that the fractured basalt aquifer is hydraulically connected throughout the lower basin but has low hydraulic conductivity ( 2 to 20 $\mathrm{m} / \mathrm{d}$ ) and storage (0.003 to 0.01$)$. The analyses of environmental tracers and hydraulic properties indicate that if the artificial recharge infrastructure is located above the upland part of the aquifer, it may eventually enhance discharge from the Galleria. However, the effect of such recharge structures on discharge from the Galleria may take decades or longer. Surface-water budget calculations and soil permeability testing for the planned artificial recharge locations would be help- 
ful for evaluating the potential amount of recharge The only other potential source of ground water in Ribeira Fajã would be additional well pumping. Such ground-water development may intercept submarine outflow, but would need to be located both sufficiently far from the ocean to avoid salt-water intrusion and sufficiently downgradient from the galleria so as not to cause decreased flow from the tunnel.

\section{References Cited}

Aeshbach-Hertig, W., Peeters, F., Beyerle, U., and Kipfer, R., 1999, Interpretation of dissolved atmospheric noble gases in natural waters: Water Resources Research, v. 35, p. 27792792.

Aeshbach-Hertig, W., Peeters, F., Beyerle, U., and Kipfer, R., 2000, Paleotemperature reconstruction from noble gases in ground water taking into account equilibrium with trapped air: Nature, v. 405, p. 1044.

Akiti, T., 1985, Environmental isotope study of the groundwaters of the island of Santiago: Vienna, International Atomic Energy Association Section of Isotope Hydrology Report, $27 \mathrm{p}$.

Andrews, J.N., 1985, The composition of radiogenic helium and its use to study groundwater movement in confined aquifers: Chemical Geology, v. 49: p. 339-351.

Ballentine, C.J., and Hall, C.M., 1999, Determining paleotemperature and other variables by using an error-weighted, nonlinear inversion of noble gas concentrations in water: Geochemica Cosmochimica Acta, v. 63, p. 2315-2336.

Barmen, G., Carvalho, V., and Querido, A., 1990, Groundwater-related geological and isotopic investigations on the island of Fogo: An overview: Lund University Institute of Technology Report TVTG-90/3027, 72 p.

Barmen, G., Joseffson, G., Magnusson, M., and Wernersson, H., 1984, A hydrogeological investigation on Santiago, Cape Verde Islands: Lund University Institute of Technology Report TVTG-5009, 43 p.

Bokuniewicz, H.J., 1980, Groundwater seepage into Great South Bay, New York: Estuarine and Coastal Marine Science, v. 10, p. 437-444.

Buchanon, T.J., and Somers, W.P., 1969, Discharge measurements at gauging stations, U.S. Geological Survey Techniques of Water-Resources Investigations, book 3, chap. A8, $65 \mathrm{p}$.

Cable, J.E., 1997, Magnitude and variations of groundwater seepage along a Florida marine shoreline: Biogeochemistry, v. 38 , p. $189-205$.
Cambereri, T.C., and Eichner, E.M., 1998, Watershed delineation and ground water discharge to a coastal embayment: Groundwater, v. 36, no. 4, p. 626-634.

Clarke, W.B., Jenkins, W.J., and Top, Z., 1976, Determination of tritium by mass spectrometric measurements of ${ }^{3} \mathrm{He}$ : International Journal of Applied Radiation Isotopes, v. 27, p. 515-522.

Coplen, T.B., Plummer, L.N., and Mullin, A., 1996, Collection, processing, and analysis of carbon isotope samples: U.S. Geological Survey National Water Quality Laboratory Technical Memorandum 96.05, 10 p.

Craig, H., 1961, Standard for reporting concentrations of deuterium and oxygen-18 in natural waters: Science, v. 133, no. 3467 , p. $1833-1834$.

Dansgaard, W., 1964, Stable isotopes in precipitation: Talus, v. 16, pp. 436-468.

Freeman, L.A., Carpenter, M.C., Rosenberry, D.O., Rousseau, J.P., Unger, R., and McLean, J.S., 2004, Use of submersible pressure transducers in water-resources investigations: U.S. Geological Survey Techniques of Water-Resources Investigations 8-A3, $65 \mathrm{p}$.

Freeze, R.A., and Cherry, J.A., 1979, Groundwater: Englewood Cliffs, New Jersey, Prentice-Hall, 604 p.

Geoffray, D., 1985, Recherches des eauz souterranes, Galerie de Faja Situation au 15 Mai 1985: Perspectives pour l'achevement des travaux et cout final actualise de la galerie, BURGEAP, Republic Francaise Ministere des Relations Exterieures, Note Technique NT 05-85, 23 p.

Gingerich, S.B., 1999, Estimating transmissivity and storage properties from aquifer tests in the southern Lihue Basin, Kauai, Hawaii: U.S. Geological Survey Water-Resources Investigations Report 99-4066, 33 p.

Gingerich, S.B., and Voss, C.I., 2002, Three-dimensional variable density flow simulation of a coastal aquifer in southern Oahu, Hawaii, USA: Hydrogeology Journal, v. 13, p. 436450 .

Haagsma, B., 1995, Traditional water management and state intervention: The case of Santo Antão, Cape Verde: Mountain Research and Development, v. 15, no. 1, p. 39-56.

Hem, J.D., 1992, Study and interpretation of the chemical characteristics of natural water: U.S. Geological Survey Water-Supply Paper 2254, 263 p.

Hidroprojecto Engenharia Gestão, 2000, Etude d'amenagement des basins versants, Phase 1: Caracterisation de la situation actuaelle et diagnostic, v. 2.5 - Bassin de Ribeira da Faja, Republique du Cap Vert Ministere de L'Agriculture, de L'Alimentation et de L'Environment, Lisbon, Portugal. 
Izuka, S.K., and Gingerich, S.B., 1998, Ground water in the southern Lihue Basin, Kauai, Hawaii: U.S. Geological Survey Water-Resources Investigations Report 98-4021, 71 p.

Izuka, S.K., and Gingerich, S.B., 2003, A thick lens of fresh groundwater in the southern Lijue Basin, Kauia, Hawaii, USA: Hydrogeology Journal, v. 11, no. 2, p. 240-248.

Kallrén, L., and Schreiber, I., 1988, Groundwater survey on western Fogo, Cape Verde: Lund University Institute of Technology Report TVTG-5019, 83 p.

Kipfer, R., Aeschbach-Hertig, W., Peeters, F., and Stute, M., 2002, Noble gases in lakes and ground waters, in Porcelli, D., and others, eds., Noble gases in geochemistry and cosmochemistry, Reviews in Mineralogy and Geochemistry, v. 47, p. $615-700$.

Langworthy, M., and Finan, T.J., 1997, Waiting for Rain: Agriculture and ecological imbalance in Cape Verde: Boulder, Colorado, Lynne Rienner Publishers, 212 p.

Lodge, A., and Helffrich, G., 2006, Depleted swell root beneath the Cape Verde Islands: Geology, v. 34, no. 6, p. 449-452.

Macdonald, G.A., Abbott, A.T., and Peterson, F.L., 1983, Volcanoes in the sea: The geology of Hawaii ( $2 \mathrm{~d}$ ed.): Honolulu, Hawaii, University of Hawaii Press, 517 p.

Manning, A.H., and Solomon, D.K., 2003, Using noble gases to investigate mountain-front recharge: Journal of Hydrology, v. 275, no. 3-4, p. 194-207.

Mazor, E., 1991, Applied chemical and isotopic groundwater hydrology: New York, Halsted Press, 274 p.

Merritt, M.L., 2004, Estimating hydraulic properties of the Floridan aquifer system by analysis of earth-tide, oceantide, and barometric effects, Collier and Hendry Counties, Florida: U.S. Geological Survey Water-Resources Investigations Report 03-4267, 70 p.

Michael, H.A., Lubetsky, J.S., and Harvey, C.F., 2003, Characterizing submarine groundwater discharge: A seepage meter study in Waquoit Bay, Massachusetts: Geophysical Research Letters, v. 30, no. 6, p. 1297.

Olivry, J.C., 1981, Estudo de precipitacoes em São Nicolau, Republica das ilhas de CV, Office de la Recherche Scientifique et Technique outre mer centre orstom de Dakar: Bureau Central Hydrologique BONDY, Republique Francaise Ministere de la cooperation e Republique des Iles du Cap Vert Ministere du developpement Rural, 55 p.

Prada, S.N., da Silva, M.O., Cruz, J.V., 2005, Groundwater behavior in Madeira, volcanic island (Portugal): Hydrogeology Journal, v. 13, no. 5-6, p. 800-812.
Rolland, C., 2003, Spatial and seasonal variations of air temperature lapse rates in alpine regions: Journal of Climate, $\mathrm{v}$. 16, p. 1032-1046.

Sabino, A.A., 1986, Proyecto de recarga de Galerie de Faja - Ilhe de São Nicolau: Ministero de Ambiente, Agricultura, e Pescas, Cabo Verde.

Sheldon, A., 2002, Diffusion of radiogenic helium in shallow ground water: Implications for crustal degassing, Salt Lake City, University of Utah, Ph.D. dissertation, 185 p.

Solomon, D.K., and Cook, P.G., 2000, ${ }^{3} \mathrm{H}$ and ${ }^{3} \mathrm{He}$, in Cook, P.G., and Herczeg, A.L., eds., Environmental Tracers in Subsurface Hydrology: Boston, Mass., Kluwer Academic Publishers, p. 397-424.

Stute, M., and Schlosser, P., 2001, Atmospheric noble gases, in Cook, P., Herczeg, A.L., eds., Environmental Tracers in Subsurface Hydrology: Boston, Mass., Kluwer Academic Publishers, p. 349-377.

Vailleux, Y., 1985, Recherches des eauz souterranes, Galerie de Faja Situation debut Mai 1984: Incidences des travaux: BURGEAP, Republic Francaise Ministere des Relations Exterieures, Note Technique NT 09-84, 20 p.

Vailleux, Y., and Bourguet, L., 1974, La mise en valeur des eaux souterraines dans l'archipel du Cap Vert: BURGEAP, Ministerio da Coordenacão interterritorial, Brigada de Aguas Subterraneas do Cabo Verde Final Mission Report 140, $291 \mathrm{p}$.

Wilde, F.D., and Radtke, D.B., 1998, National field manual for the collection of water-quality data, Field measurements: U.S. Geological Survey Techniques of Water-Resources Investigations, book 9, chap. A6, 233 p. 


\section{疍}

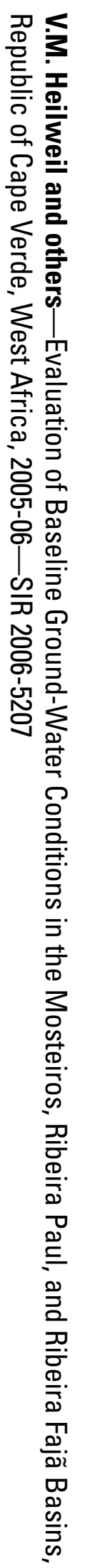

